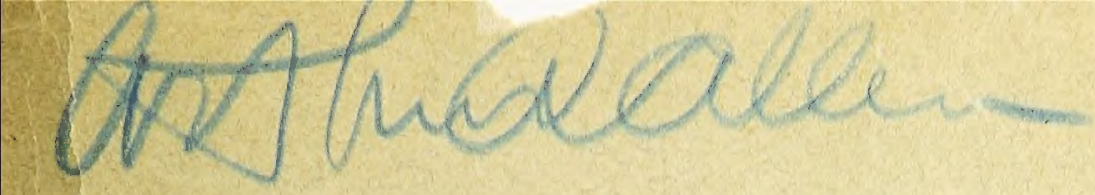

The University of the State of New York The State Department of Education

Visual Instruction Division

\title{
SLIDES AND PHOTOGRAPHS
}

List 29

BIRDS OF NEW YORK STATE

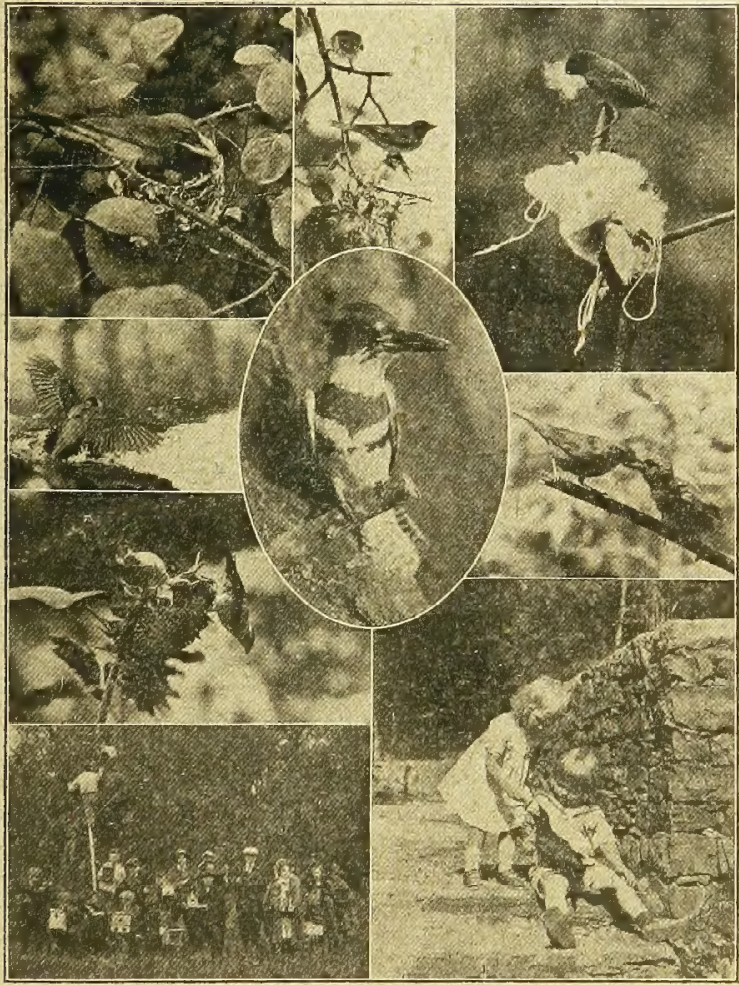

ALBANX, N. Y.

1920 
THE UNIVERSITY OF THE STATE OF NEW YORK

Regents of the University

With years when terms expire

(Reyised to February, 5 , I920)

1926 PLINY T. Sexton LL.B. LL.D. Chancellor - - Palmyra

Í27 ALBetrt VANDer Veer M.D. M:A. Ph:D. LL.D.

Vice Chancellor Albany

I922 CHESTER S. LoRD M.A. LL.D.

ig30 Willam NotTINGhaM M.A.Ph.D. LL.D. - - Sytacuse

Tó2 AdetaERT Moot LLD

I925 Charies B, ALEXANDER M.A. LL.B. LL.D.

Litt.D. - - - - - Tuxedo

1928 WALTER GUEST KeLlOGg B.A.LL.D. - - Ogdensburg

rg32 JAMES BYRNE B,A. LL.B. LL.D - - - - New York

1929 HeRBERT L. BRIDGMAN MA. - - Brooklyn

93 I Thomas J. MANGAN MA. - _ _ _ - Binghamton

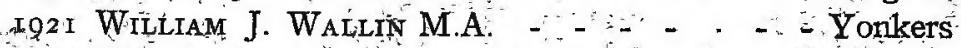

1923 WILLIAM BONDY MA: LL.B. PH.D _ - - New York

President of the University and Combissioner of Education

JohN H. FINLEY M.A. LL.D. L.H.D.

Deputy Commissioner and Counsel

Frank B. Gildert B.A.

Assistant Commissioner and Director of Prófessional Education

Augustús S, Downing M,A L.H.D. LL.D. PA.D.

Assistant Commissioner for Secondary Education

Chakies F. WHEelock B.S. LL.D.

Acting Assistant Commissioner for Elementary Edupation ?

George M. Wiley, M.A.

Director of State Libraty

JAMES I."WYER, JR,-M.L.S. Pd.D.

Director of Science and State Museim.

JOHN M CLARKE D.Sc. LL.D.

Administratiơn, HRAM C. CASE

Agricultural and Industrial Education, LewIS A. Wrisow

Archives and History, James Sullivan M.A. Ph.D.

Attendance, JAMES D. SullivaN

Edicational Extension; WILlaM R. WATSON B.S:

Examinations and Inspections, GEORGE M: WIIE M.A.

Law, Frank B. Gilbert B.A., Coninsel

Library Schoól, JAmês I. WYER, JR, M.L.S. Pd.D.

School Butildings and Grounds, FranK H. WOOD M.A.

School Libraries, Sherman WILLIAMS PdDD.

Visual Instruction, AlFRed W. Abrams Ph.B. 


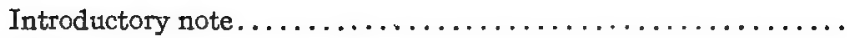

Bibliography

List of slides and photographs

Titles arranged alphabetically by name of bird..........6676 8

Topical studies

Mating and nesting......................... $73 \quad 123$

Eggs...................................... $59 \quad 129$

Young................................ $44 \quad 134$

Distribution of birds that nest in New York............. $69 \quad 139$

Structure and habits............................ $66 \quad 143$

Coloration ............................. $49 \quad 147$

How to attract.......................... $42 \quad 152$

Flight................................... $46 \quad 155$

Migration.................................. $54 \quad 163$

Economic importance........................... $59 \quad 167$

Photography............................. $9{ }^{171}$

Total, less duplicates................. $\overline{700}$ 


$$
\begin{aligned}
& \text { ORNITH } \\
& \text { QL } \\
& 684 \\
& N 7 \\
& 455 \\
& 1920
\end{aligned}
$$




\section{INTRODUCTORY NOTE}

Contents. This collection of pictures contains 700 titles representing 162 species. It is confined to birds of New York, and includes most of the more common and many of the rarer ones. Additions will continue to be made, but in its present form the list is exceptionally complete and representative.

Character. The collection is distinctive in that it consists almost exclusively of photographic productions from living specimens of birds, nests and eggs in their normal position, and actual habitats. No drawings are included except that of the topography of the bird and seven migration maps. The only museum specimens included are those of the auk and the passenger pigeon, now extinct birds, and two others used to illustrate special features. Of course birds too young to have finally left the nest were in some cases placed upon a perch for photographing. Some adults were photographed at feeding stations or on specially placed perches, but one has only to compare these pictures with drawings and photographic representations of museum specimens to appreciate the important differences in appearance and attitude between living birds and inanimate specimens and drawings. Several years have been spent in the preparation of this collection.

Sources of the collection. Users of these pictures are chiefly indebted to the work of two exceptional bird students and photographers of the State, Dr Arthur A. Allen of Cornell University and Guy A. Bailey of the Geneseo State Normal School. The following is a list of contributors with the number of pictures furnished by each:

Arthur A. Allen............ 230

Guy A. Bailey.............220

William L. Baily........... 3

R. H. Beebe............. 32

C. W. Beebe............. 3

G. S. Britten............. 1

Verdi Burtch ............. 33

Frank M. Chapman......... 15

William Dutcher ........... 2

G. C. Embody............. 1

Clyde C. Hamilton.......... 1
T. L. Hankinson........... 3

Francis Harper ........... 23

H. S. Hathaway........... 1

R. W. Hegner............. 7

H. W. Nash............. 1

P. B. Peabody ............. 2

C. F. Stone............... 9

E. G. Tabor.............., 10

C. O. Widman............. 1

F. A. Van Zant............. 2 
Arrangement. The names of birds are arranged alphabetically. The general order of the titles for each species is as follows: that of adult most suitable for a study of the form, color and size of the bird; nest; incubation; nestlings; feeding; other aspects.

Notes. Books and magazine articles on birds are numerous and generally accessible. They should be the chief dependence of those wishing verbal information about birds. It has, however, seemed advisable to offer a brief introductory note to each bird to give those who are just beginning to work in this field of study a general notion of where a certain bird belongs in the bird life of the State.

The notes under the separate titles are not such verbal descriptions as are usually found in books. The aim is to direct observation to certain specific features well illustrated by the picture. Collectively these notes point out the inductive method of studying birds.

Whether the slides of this collection are used for lecture purposes or for classroom study they offer ample means for a large number of exercises. It is expected that schools and clubs organized for bird study will make provision for a systematic use of the collection.

In preparation of notes and organization of material much assistance has been received from Doctor Allen, Professor Bailey and others, who have been frequently consulted. The topical studies following the list of birds are chiefly the work of Doctor Allen.

Use. In many schools there are one or more teachers who have become bird students or being interested in nature study would like to take up for a time the study of birds. Much could be accomplished if the pupils of a single grade were to devote a large part of the entire year to birds. At the end of the year they would possess a substantial fund of knowledge of bird life and would have had opportunity for training in observation along this line. The stimulus to topical reading would also have been very great. It would seem that such work might be done very profitably in grades 4 or 5 or perhaps in one or two others.

For such an occasion as Bird Day several grades or the whole school might properly be assembled to observe the day by seeing a lot of bird pictures. 'The object here is, however, quite different from that of the work suggested above. 
Importance of bird study. The fitting of a person to enjoy and interpret nature as it is met from day to day by training him to observe what is seen is itself a sufficient reason for the circulation of such a collection of bird pictures as this one. But a further justification for the expenditure of much time and money in a very careful selection of these pictures is the fact that birds play a most important part in the economic life of the world. The function of birds in destroying weeds and harmful insects and in maintaining the general balance between plant and animal life and between different species is coming to be well understood. Bird study is of the greatest importance to agriculture and calls for systematic and intelligent attention. The pictures of this collection will be of permanent interest and their usefulness will increase as they become better known and more generally used by teachers and others.

Bird songs and calls. Most books describing birds attempt to indicate the songs and calls of different species. The notes of this list omit them altogether not because they are unimportant but for the obvious reason that sounds are not to be acquired visually. By keeping clearly in mind what elenents of knowledge are conveyed by pictures time will be saved and the ends of visual instruction more fully attained.

\section{A. W. Abrams}

Chief, Visual Instruction Division

Albany, N. Y, December 15, 1919 


\section{Bibliography}

Allen, Arthur A. The Red-winged Blackbird: a Study in the Ecology of a Cattail Marsh, in Abstract of Proceedings, Linnaean Society of New York, Nos, 24 and 25. 1911-13

Birds in Their Relation to Agriculture in New York State. New York State College of Agriculture, Cornell University (free pamphlet)

American Ornithologists' Union. Check-list of North American Birds. 1910

Bailey, Mrs Florence A. (Merriam). Birds of Village and Field, a Bird Book for Beginners. Houghton Mifflin Company

Baynes, Ernest Harold. Wild Bird Guests. E. P. Dutton \& Co.

Burroughs, John. Wake-Robin. Houghton Mifflin Company

Bird Stories from Burroughs. Houghton Mifflin Company

Chapman, Frank M. Bird Life-a Guide to the Study of Our Common Birds. D. Appleton and Co.

Handbook of Birds of Eastern North America. D. Appleton and Co.

Color Key to North American Birds. D. Appleton and Co.

Our Winter Birds. D. Appleton and Co.

The Travels of Birds. D. Appleton and Co.

The Warblers of North America. D. Appleton and Co.

Doubleday, N. B. (Neltje Blanchan). How to Attract the Birds and Other Talks about Bird Neighbors, Doubleday, Page \& Co. 1903 Library)

Bird Neighbors. Doubleday, Page \& Co. 1905 (The Nature

Birds That Hunt and Are Hunted. Doubleday, Page \& Co. 1905 (The Nature Library)

Dugmore, A. Radclyffe. Bird Homes. Doubleday, Page \& Co. 1905 (The Nature Library)

Eaton, Elon Howard. Birds of New York. 2v. University of the State of New York, Museum Memoir 12: part 1, Introductory chapters; water birds and game birds; part 2, General chapters; land birds.

Finley, William L. \& Irene. Little Bird Blue. Houghton Mifflin Company

Adapted to pupils of primary grades

Forbush, Edward Howe. Useful Birds and Their Protection. The Massachusetts State Board of Agriculture. 1913

Gilbert, Albert F. Birds of Field, Forest and Park. The Page Company Birds through the Year. American Book Co.

Grinnell, Elizabeth \& Joseph. Our Feathered Friends. D. C. Heath \& Co.

Headley, F. W. The Flight of the Birds. Charles Scribner's Sons

Herrick, Francis Hobart. The Home Life of Wild Birds - A New Method of the Study and Photography of Birds. G. P. Putnam's Sons Hoffman, Ralph. A Guide to the Birds of New England and Eastern New York. Houghton Mifflin Company 
Job, Herbert Keightley. How to Study Birds. Outing Publishing Company

The Sport of Bird Study-a Book for Young or Active People. Outing Publishing Company

Miller, Olive Thorne. The Children's Book of Birds. Houghton Mifflin Company

Combines First and Second Books of Birds

Pearson, T. Gilbert. The Bird Study Book. Doubleday, Page \& Co. Tales from Birdland. Doubleday, Page \& Co.

Reed, Chester A. The Bird Book. Doubleday, Page \& Co. Nature Study-Birds. Doubleday, Page \& Co.

A book for children

Stickney, J. H. Bird World. Ginn and Co.

Trafton, Gilbert H. Bird Fricnds. Houghton Mifflin Company

Method of Attracting Birds. Houghton Mifflin Company

Walker, Margaret C. Our Birds and Their Nestlings. American Book Co.

Weed, Clarence M. \& Dearborn, Ned. Birds in Their Relations to Man. J. B. Lippincott Company

Wicks, John Bartlett. Bird Paradise. George W. Jacobs \& Co.

Wright, Mabel Osgood. Birdcraft. The Macmillan Company Gray Lady and the Birds. The Macmillan Company

Wright, Mabel Osgood \& Coues, Elliott. Citizen Bird. The Macmillan Company

\section{Publications of United States Department of Agriculture}

Beal, F. E. L. The Crow Blackbirds and Their Food. Reprinted from the Yearbook of the U. S. Department of Agriculture for 1894 - Preliminary Report on the Food of Woodpeckers; Lucas, F. A. The Tongues of Woodpeckers. Bulletin 7, 1895

Food of Our More Important Flycatchers. Biological survcy Bulletin 44, 1912

280,1915 630,1918

Beal, F. E. L. \& McAtee, W. L. Food of Some Well-known Birds of Forest, Farm and Garden. Farmers' Bulletin 506

Cooke, Wells W. Bird Migration. Bulletin 185, 1915

Dearborn, Ned. Bird Houses and How to Build Them. Farmers' Bulletin 609, 1914

McAtee, W. L. How to Attract Birds in Northeastern United States. Farmers' Bulletin 621, 1914

\section{Periodicals}

Auk. American Ornithologists' Union, publishers

Bird-lore. Official organ of the Audubon Socicties. D. Applcton \& Co., publishers 


\section{LIST OF SLIDES AND PHOTOGRAPHS}

Unless otherwise indicated, the place named in the title is in every case in New York State.

Call no.

Nu 2 Topography of a Bird. From drawing by Chester 1 . Recd in Frank M. Chapman's Color Key to Norlh Amcrican Birds

Copyright, 1912, D. Appleton \& Co. By permission of the publishers

$\mathrm{Nu} 4$ Skelcton of a Fowl (Gallus domesticus)

\section{Auk, Great (Plautus impennis)}

This bird is now extinct, no living specimen of it having been observed since 1842. A motive for including a picture of the bird in this list is the opportunity to direct attention to the fact that numerous other species also are likely to become extinct unless adequatcly protected. See passenger pigeon, Nu PmP and $\mathrm{Nu}$ PnP8.

Nu AuG Adult (museum specimen); an Egg. American Museum of Natural History, New York. (1917)

Note the short wings. The bird was flightless and hence easily killed by early voyagers and fishermen who visited its breeding grounds, which were distributed along the Atlantic coast from the Arctic regions to Massachusctts. It was able to escape its natural enemies on the sea by diving, but nature had not provided against the coming of man to its nesting islands. Compare with penguins.

\section{Baldpate (Mareca americana)}

'Though not one of the commoner ducks of New York, the baldpate, also called American widgeon, is found on the protected waters of Gardiners island occasionally during the winter. It is found elsewhere in the State as a fairly common migrant. Flesh estecmed as food.

18-21*

$\mathrm{Nu}$ Bc1 Adult Male Dropping Down to Alight among Decoys on Water. Gardiners island. (April 8, 1912)

Harper $\dagger$

* Figures found in this position throughout the list indicate the length of the bird in inches. They are not to be memorized but should be noted frequently with a view to establishing a correct mental picture of the size of the bird.

t The name appcaring in italics in this position is that of the photographer. 


\section{Baldpate (continued)}

"The bird "backpedals" with its wings and also thrusts out its fect to help stop its momentum. It always faces the wind in alighting. The white crown shows that it is an adult male.

Call no,

$\mathrm{Nu}$ Bc8 lilock in Flight over the Watcr. Gardiners island. (April 8, 1912)

Harper

Describe the mode of flight both as to an individual bird and as to the flock. Note the large white patch on wing and the light underparts. These are the field marks.

\section{Bittern, American (Botaurus lentiginosus)}

The American bittern, or "stake driver," is a summer resident of large swamps and marshes throughout the State, being especially common in the Montezuma marshes. It builds its nest of grass and reeds on the ground. It is a solitary bird; that is, it is not found in flocks. The food of the bittern consists of irogs, fish, salamanders and water insects. Does the location of the nest suggest this fact?

Nu BiA Adult Disturbed While Brooding, Two Young Birds at Side. Montezuma marshes. (1904)

Tabor

This particular bird had no fear in defending its nest. If approached too closely, it struck with its bill. Note how the young birds imitate the mother in the position they assume. Yote the character of the regetation around the nest and compare with the other pictures showing the habitat of bitterns.

Nu BiA2 Nest with Eggs Nearly Submerged in Water. Branchport. (May 21, 1912)

Burtch

In periods of high water the bittern, like the gallinule, builds its nest up from the bottom by the repeated addition of new material. Even then the nest may be destroyed by the rising water. This nest is in a much more exposed situation than is usual.

Nu BiA5 Four Birds About Two Weeks Old on Nest. Montezuma marshes. (1904)

Tabor

Observe the characteristic position of the head and of the neck. Describe each. The young are now strong enough to defend themselves and are ready with bills open to strike at the photographer. Note the feathers appearing on shoulder and wing. 
Call no.

\section{Bittern, American (continued)}

Nu BiA6 Two Young Birds of Same Brood but Different Size. Renwick marsl, near Ithaca. (June 12, 1909) Allen

Incubation with this bird usually begins with the laying of the first egg. Hence the eggs hatch unevenly and the young are of different sizes. Extremes of one brood are shown here. Note the coating of long down, which nearly covers the body.

Nu BiA7 Roost in Thick Growth of Horsetail. Renwick marsh, near Ithaca. (June 8, 1909)

Allen

Such a roost keeps the bird out of the water and above its enemies while sleeping. What enenies? Probably a new roost is made each night. The reeds in the foreground have been cut away to show the roost. The feather indicates that the bird probably preened its feathers before leaving the roost.

Nu BiA8 Adult Rising in Flight from Nest in Sedges. Renwick marsh, near Ithaca. (June 8, 1909)

Harper

The bird is working its wings very vigorously to get under way. In the nest were several young birds and the adult remained with them until the photographer had approached rather close to it. The position of the legs and toes indicates the effort put into the initial spring from the nest. Compare with $\mathrm{Nu}$ BiA9.

$\mathrm{Nu}$ BiA9 Adult in Flight. West marsh, near Ithaca. (June 2, 1909) Allen

Note the large wings, the legs held out behind and the long neck, which is not folded back onto the shoulders as much as in other herons. See Nu HeF6. The feet are held out somewhat behind to serve the purpose of a long tail.

\section{Bittern, Least (Irobrychus exilis)}

The least bittern is less widely distributed than the American. It is seldom found in upland districts. It lives in swamps and builds a nest of reeds a foot or more from the water in cat-tails or rushes. It is the smallest of the heron family. Compare with the American bittern, which is much larger.

11-14.25

Nu BiL Male Incubating. Ithaca. (May 31, 1914)

Allen

Note the black back, proving that it is a male. The male and female take turns incubating. 
Call no.

\section{Bittern, Least (continued)}

Nu BiL2 Adult Female Leaving Nest, Three Eggs in Sight. Montezuma marshes. (1904)

Tabor

Compare with male as to color. The least bittern is a slim bird. This picture represents it in a disturbed condition as it is rising from the eggs. Here the wing is dropped and the feathers shaken out, thus making the bird appear larger and heavier than it is. When examining certain other pictures, keep this habit of birds in mind.

Nu BiL24 Adult Female Defending Nest and Eggs. Renwick marsh, near Ithaca. (June 3, 1914)

Allen

This bird knew no fear in the defense of her home and struck at the hand of the photographer.

Nu BiL3 Nest with Five Eggs. Montezuma marshes. (1904) Tabor

$\mathrm{Nu}$ BiL4 Young Bird with Conspicuous Pin Feathers. Branchport.

(June 26, 1914)

Burtch

Note also the downy feathers on back and head. These young birds will leave the nest and climb away through the flags with surprising rapidity. The camera was close to the bird, which is actually much smaller than it appears. For size, compare with cat-tails upon which it stands.

Nu BiL5 Female with Young, Neck Swollen with Food. Ithaca. (July 1917)

Allen

The bittern regurgitates its food.

Nu BiL7 Female on Nest in the Reeds Pointing, "Broken Reed Posture"; Two Eggs in Sight. Near Ithaca. (June 3, 1914)

Allen

This is an excellent illustration of protective mimicry, the bird by its position as well as by its color simulating a broken reed. Note the position of the eyes.

Nu BiL8 Female on Back of Nest Showing "Swaying Reed Posture"; Six Eggs in Nest. Near Ithaca. (June 3, 1914)

Allen

Here the feathers of the neck are shaken out until the streaks form lines like the light and shadow between the reeds. When 
in this posture, the bird rotates its head so as always to face the intruder and sways its head and neck with the reeds blown by the breeze.

\section{Blackbird, Red-winged (Agelains phoniceus phoniceus)}

This bird is a little smaller than the robin. It is common throughout the State during the entire summer. In the spring and fall it migrates in flocks of 30 to 300 . It is a sociable bird and gathers in larger numbers, particularly in the fall, in its favorite haunts. It is friendly with birds of other species.

$$
\text { ơ } 9.5-9.75 ; \text { ㅇ } 7.5-8
$$

Call no.

Nu Bl Adult Male, Profile. Geneseo. (September 1914) Bailey

The male is distinguished by its bright scarlet lesser wingcoverts edged with yellow. Note a second bird, a female, in the background, out of focus.

Nu Bl1 Adult Female on Bent Sapling near Nest, Front Vicw. Geneseo. (May 1910)

Bailey

The female differs decidedly in color and size from the male. How? Her spotted breast and lack of red shoulders serve to distinguish her at a distance. The limb on which the bird has perched is close to her nest. The camera is over the nest. The alarm of the bird, as shown by her pose, is due to the camera. When the nest is approached, she always comes nearer to the intruder and risks herself in defense of her young.

\section{$\mathrm{Nu} \quad \mathrm{B} 12$ Low Nesting Site in Rank Herbage}

Blackbirds nest in what is known as the herb stratum, that is, in tussocks of grass or flags or among tangles of ferns and weeds or in bushes occurring in all the zones of marsh vegetation but preferring cat-tails. Note the location and structure of nests in other pictures. Nests vary considerably as to location, but they are seldom more than four or five feet from the ground, commonly nearer. This nest is in the alders fringing a marsh.

Nu B122 Pair of Adults on Cat-tails. Renwick marsh, near Ithaca

Allen

This picture shows characteristic poses of the birds and also indicates the kind of a place where they are commonly found. They specially like reeds and low bushes on the margin of ponds and marshy streams. Which is the male? 


\section{Blackbird, Red-winged (continued)}

Call no.

Nu B124 The Beginning of a Nest. Renwick marsh, near Ithaca. (May 21, 1910)

Allen

Note how these first fibers are woven in and out among the sedges. How does the bird get these fibers? Of what advantage are they?

Nu B125 Nest with Five Eggs in Clump of Green Arrow Arum (Peltandra rirginica). Renwick marsh, near Ithaca. (Junc 8,1907 )

Allon

Note date. Nests built late in the season are often placed in the softer vegetation about ponds and streams, bccause the cattails and sedges have then become very harsh. The nesting season is short.

Nu Bl3 Nest Turned onto One Side by Growth of Part of Vegetation to Which It Is Attached. Renwick marsh, near Ithaca. (May 19, 1910) Allen

One side of the nest is attached to dead stubs of cat-tails, the other to rapidly growing leaves. Many nests are capsized this way. What may have happened to the rest of the eggs?

$\mathrm{Nu}$ B132 Nest and Broken Eggs in Reeds, Oncida lake. (May 1908)

Bailcy

The eggs in this nest have been pierced, probably by the longbilled marsh wren. In swamps, where red-winged blackbirds and long-billed marsh wrens nest side by side, it is not unusual to find the eggs of the blackbirds destroyed in this way. 'The last two pictures indicate some of the agencies through which the increase of bird life is retarded.

Nu B136 Fcmale Incubating, Nest in Coarse Bog Grass. Arcade. (1909)

Beebe

The bird has its mouth open on account of the heat, the grass around it having been pressed down for the purpose of photographing. This nest is much nearer the ground than is customary.

$\mathrm{Nu}$ Bl38 Four Pictures Showing Growth: Young Bird Hatching; Birds Five Days Old; Bird Nine Days Old; Bird 10 Days Old. Renwick. (May and June 1910) Allen

(1) Contains two eggs and onc young bird not able to raise his head, blind, helpless, with only a little down along the prin- 


\section{Blackbird, Red-winged (continued)}

cipal feather tracts. (2) Feather tracts conspicuous, eyes open. (3) Able to fly somewhat although the feathers do not yet cover all the bare spaces; down still attached to feathers of head. (4) Ready to leave nest; bare spaces all covered except around eye; down still clinging to feathers.

Call no.

Nu B14 Four Birds About 10 Days Old, with Open Mouths, Posed on a Broken Cat-tail

Chapman

Which parent do they resemble? Note the down still attached to the feathers of the head.

Nu B144 Female Perched above Nest, Bringing Food to the Young. Renwick marsh, near Ithaca. (May 18, 1910) Allen

In this case the food is mostly May flies. Blackbirds eat some of the farmer's grain, especially corn in the milk, but they live much more on insects and weed seeds injurious to him. They do much more good than harm to agriculture.

Nu Bl46 Adult Feeding Young in Nest. Renwick marsh, near Ithaca. (June 1910)

Allen

The food is placed far down the throat of the young birds.

Nu B15 Female Inspecting Nest after Feeding the Young. Renwick marsh, near Ithaca. (June 1910)

Allen

The redwing, like most other birds, looks very carefully after the sanitary conditions of the nest. It allows nothing to remain in the nest that would foul it. Such an inspection is a regular performance.

Nu B152 Female Cleaning Nest after Feeding the Young. Renwick. (June 1910)

Allen

After each feeding all excrement is scrupulously removed from the nest. Note how the body is suspended by its legs attached to a reed on either side.

Nu B158 Female About to Fly Away from Nest with Excrement. Renwick marsh, near Ithaca.

Allen

The excrement of birds generally is inclosed in a white mucous sack. 
Call no.

\section{Blackbird, Red-winged (continued)}

Nu B17 Female on Cat-tail in Restful Position. Renwick marsh, ncar Ithaca. (June 1910)

Allen

This is a common pose when the bird does not suspect anyone is near.

Nu B18 Female on Old Cat-tail Pcrched near Nest, Scolding. Renwick marsh, near Ithaca. (June 1910) Allen

This is a characteristic attitude of the bird when someone approaches the nest.

Nu B19 Female Stretching, Right Foot Extended. Gencsco. (August 1915)

Bailey

Many such activities of a bird commonly escape attention.

Nu B192 A Very Large Flock Disturbed from Feeding on Field of Oats. Near Hornell. (August 1916)

Nu B195 Large Flock of Red-winged Blackbirds and Bronzed Grackles on Branches of Elm Tree. Branchport. (April 2, 1911) Burtch

Blackbird, Yellow-headed (Xanthocephahis xanthocephalus)

This bird belongs to western North America. It is accidental in New York, where it has been recorded only once.

đิ $10.6-11$; 9 9-10

Nu BIY Adult on Edgc of Nest Attached to Reeds

Bluebird (Sialia sialis sialis)

One of the first birds to announce the approach of spring and one of the last to leave in the late fall. The males usually precede their mates in coming north in March. Not all the bluebirds migrate from the State in the fall; some remain as permanent residents in the lower Hudson valley and on Long Island.

This is one of the most lovable of birds. It seems to have no disagreeable characteristics. Its color is beautiful, its voice is mellow and its food habits are beneficial to man. It frequents orchards, gardens, stump lots, rail fences and vineyards.

$6.5-7$ 
Call no.

\section{Bluebird (continuted)}

Nu Bm Malc (left) and Female (right), Front Vicw, with Food on Stump. Arcade. (1909)

Bccbe

Note that both bircls have food and that it consists of insects, the male having several worms or larvæ. More commonly, however, the female gives more attention to feeding the young and does most of the work of preparing the nest. The picture also illustrates the bluebird's fondness for stumps in open pastures. Study carefully the differences in the color of the two birds.

Nu Bml Female on Electric Percll with Insect Food in Beak, Profile

Chapman

The electric perch is a device for photographing automatically the bird when it alights on it. Blucbirds feed upon many kinds of destructive insects. They get most of them from the ground, but will sometimes seize them in the air.

\section{$\mathrm{Nu} \mathrm{Bm} 2$ Nesting Sites in an Old Applc Trec}

Old apple and pear trees are favorite nesting places for blucbirds. The various woodpeckers provide nesting places for them for the reason that the former, as a rule, use a new nest each year. This tree had three kinds of birds nesting in it at one time. The bluc bird will also occupy boxes erected for the purpose.

Nu Bm3 Nest and Four Eggs in Hollow of Tree Trunk

A piece of wood was removed to photograph the eggs. When it was replaced the bluchirds returned to the nest regularly and were not disturbed. The claws of young bluebirds are sharp. Does the picture suggest the need of such claws?

Nu Bm32 Same Hollow of Trec as in $\mathrm{Nu} \mathrm{Bn13}$ with Young Birds

Nu Bm4 Two Young Birds Taken Out of Nest and Placed on a Stump. Geneseo. (June 1902) Bailey

The young birds remain in the nest until they are ablc to fly, about 15 days. When removed forcibly and placed in an exposed position, they crouch down and attempt to hide as they did when they were in the nest, an instinct of self-preservation. Note the spots on back and breast, a typical thrush color pattern that the adults do not have. 


\section{Bluebird (continued)}

Call no.

Nu Bm5 Four Young Birds Pcrched on Small Limb. Arcade. (1908)

Becbe

Two broods are rcared in a season.

Nu Bm56 Adult Female on Stump before Young Bird with Mouth Opcn for Food. Arcade. (1908)

Becbe

A young bird seems always to be ready to eat, but in this case the mother has no food for him.

Nu Bm62 Adult Leaving Nest in Tree, Head and Neck Showing. Onondaga Valley. (1902)

Bailey

This nest was built in a cavity in an apple tree where a limb had been cut off and become decayed.

Nu Bm7 Adult Femalc on Mullein Stalk. Arcade. (1905) Becbc

At what season of the year is this?

Nu Bm8 Adult Flying

Allen

Note the position of wing and tail, the slightly spread primaries and the spurious wing.

For map showing winter and summer range of this bird, sec Nu ZM2, p. 166.

\section{Bobolink (Dolichonyx orywivorus)}

Known also as reedbird and ricebird. This bird probably breeds in every county of $\mathrm{New}$ lork Statc. It is less common in the Adirondacks and the Catskills and on Long Island. It is sociable and a great singer. By July 20th it has lost its black and white coat and has ceased to sing. After this the male and femalc are scarcely distinguishable by color. In the southern States the bobolink, there known as the ricebird, does considerable damage to the rice fields, but in New York is one of the most beneficial birds.

of $7.25-8$; $96.5-7$

Nu Bo Adult Male Perched on a Stem with Food in Mouth. Canoga, near Cayuga lake. (June 24, 1914) Allen

The characteristic pose of the bird at the nesting season. The food in this case consists of a grasshopper and two army worms, two of the most destructive field pests in New York. 
Call no.

\section{Bobolink (continued)}

Nu Bo1 Adult Female on Moth Mullein Stalk (Verbascum Blattaria) in Blossom. Canoga, near Cayuga lake. (June 25, 1914)

Allen

A characteristic pose on a favorite plant. Observe the color as compared with the male.

Nu Bo2 Nest and Six Eggs in Grass on the Ground

The bobolink nests in meadows and pasture lots. The nest is of simple construction, a depression lined with dry grasses. It is difficult to find. Here the grass protecting it has been turned back.

Nu Bo4 Young Birds Ready to Leave the Nest; an Unhatched Egg Thrown from the Nest. Canoga, near Cayuga lake. (June 24, 1914)

Allen

The young birds remain in the nest about 10 days. What effect will continued early mowing of the meadow have on the prevalence of the bobolink?

$\mathrm{Nu}$ Bo5 Young Bird on Perch

Bailey

Note the wing feathers breaking through their sheaths.

For map showing distribution and migration of this bird, sec $\mathrm{Nu}$ ZM25, p. 166.

\section{Bobwhite (Colinus virginianus virginianus)}

This bird is often called the quail. It has become a rare bird in New York except on Long Island and in the Delaware and lower Hudson valleys.

Nu Bp2 Nest with Twelve Eggs on Ground. Near Conesus lake. (August 2, 1915) Bailey

The nest is commonly placed under a small bush or a bunch of grass or beside a fence. A large number of eggs are laid and a second brood is sometimes reared. Why, then, does this bird not increase rather than diminish in number?

This nest was deserted because a mowing machine had removed the "cover" from about the nest. Note that the nest was photographed in August while the bird nests as a rule in May.

Nu Bp4 Adult on Nest. Russellville, Ky. (September 13, 1905) 


\section{Bunting, Indigo (Passerina cyanea)}

The haunts of this bunting are in brushy hillsides, slashings and bushy gardens. It is a small bird, not quite so large as a house sparrow but the female has something of the appearance of a sparrow. It is a common bird in central and western New York and also in the coastal district.

$5-5.75$

Call no.

Nu BuI Adult Male on Stick at Fceding Station. Ithaca. (May 29. 1917)

Allen

The bird has been attracted by millet during a cold spell when insects were hard to find. This species usually feeds on insects during the summer and on seeds during the fall and winter.

Nu BuI2 Adult Female on Side of Nest in Raspberry Bush. (June $10,1915)$

Allen

The bunting builds a soft, tufted nest of vegetable fiber, usually with a number of dead leaves woven into the foundation.

Nu BuI3 Adult Female Incubating. (June 16, 1915)

Allen

$\mathrm{Nu}$ BuI4 Nest and Eggs with Cowbird's Egg in Black Raspberry Bush. Geneseo

Bailey

At what time of year was this taken?

$\mathrm{Nu}$ BuI5 Adult Male Clinging to Pcrch over Nest with Young; Nest Decorated with Cotton. Ithaca. (June 24, 1917)

Allen

It is unusual for the male to feed the young, but the young birds expect food. Compare coloring of male and female. Note the cotton in the nest. Indigo birds generally use dead leaves but these used cotton put out for them.

\section{Bunting, Snow (Plectrophenax nivalis nivalis)}

Also called snowflakc. Holarctic in distribution. Common winter visitant in New York, though rather irregular in occurrence.

ơ 7-7.35; 우 6-6.5

Nu BuS6 Adult Feeding upon Grain Spread on Snow. Geneseo. (March 5, 1916)

Bailey

One of the weed destroyers. 


\section{Canvasback (Marila z'alisincria)}

The canvasback visits the central lakes of New York in considerable numbers, but it is not a common duck elsewhere in the State. Its favorite food is the wild celery, which imparts a delicate flavor to the flesh. This has given the canvasback a reputation for delicious meat, but in fact several other ducks, when they have fed on the same food, are quite as satisfactory. Like most other wild ducks, the canvasback breeds north of New York. It winters in this region and farther south. 20-24 Call no.

Nu Ca1 Adult Male (captive) Standing on Rait. Ithaca. (March 25, 1917)

Allen

Note the large feet and the position of the legs, characteristic of all diving ducks.

Nu Ca6 Flock of Ducks Swimming; Canvasbacks and Bluebills. Ithaca. (March 12, 1916)

Bailey

Beneath these ducks on the bottom in about 6 feet of water are wheat and cracked corn. Note one duck in the act of diving. As many ducks are under water as are shown in the picture. The ducks with whitc backs are male canvasbacks, the one farthest back is a female; those with gray backs and white flanks are male bluebills, the dark ones with white at the base of the bill are female bluebills.

$\mathrm{Nu} \mathrm{Ca} 7$ Large Flock in Open Water Surrounded by Ice. Branchport. (March 3, 1914)

Burtch

$\mathrm{Nu}$ Ca8 Four Adult Males on the Ice, Wealiencd by Hunger. Lake Keuka. (March 1914)

Stonc

The ducks were in such a weakence condition because of inability to securc food that the photographer was able to approach very close.

Nu Ca9 Flock in Flight, Rising from the Watcr. Branchport. (March 3, 1914)

Burtch

The diving ducks do not rise straight into the air but have difficulty in getting under way, pattering over the surface for some distance.

Nu Ca92 Canvasbacks, Black Ducks and a Bluebill. Cayuga lake. (February 28, 1916) Allen 


\section{Cardinal (Cardinalis cardinalis cardinalis)}

The cardinal is a resident of the southern states and rarely comes as far north as New York State. It is not migratory in habit. The cardinal is a local resident of Staten Island and the counties of the lower Hudson valley west of the river, especially in Rockland county.

8.25

Call no.

$\mathrm{Nu} \mathbf{C b}$ Adult Malc at Fceding Station. Ithaca. (1914)

Allon

This particular bird spent part of the winter and early spring of 1914 in Ithaca. Note that at the moment it was photographed its tail and crest were down. What is the color of the female? Upon what has this bird been feeding?

\section{Catbird (Dumetella carolinensis)}

The catbird is to the North in quality of song and in imitating other birds what the mocking bird is to the South. The disagreeable note that it gives when alarmed and which sounds like the cat is not the real song of the bird. It has several beautiful songs.

This bird is not found in the depths of the woods, but is common near farm houses and in cities and villages. It is a beneficial species, living on injurious insects in the spring and summer and wild fruit in autumn; but it is also fond of cherries and cultivated berrics.

$\mathrm{Nu}$ Cd Adult on Pcrch ncar Nest. (1908)

Bailey

Note that the crown and tail are darker than the rest of the bird.

Nu Cd2 Nest with Five Eggs

Notice the materials of the nest and the location among dense foliage. The catbird seems to prefer to nest in the shrubbery near human habitations. The outer portion of the nest is made of twigs and leaves, the lining of rootlets. The nest is well built, deeply hollowed but has no soft materials. For size of egg compared with that of spotted sandpiper, see $\mathrm{Nu} \mathrm{Cd} 3$, p. 130.

$\mathrm{Nu} \mathrm{Cd} 4$ Incubating; Nest in Thicket of Grapevines and Virginia Creeper. Ithaca. (June 15, 1911)

Allen 
Call no.

\section{Catbird (continued)}

Nu Cd6 Adult at a Bathing Place. Geneseo. (Junc 15, 1915) Bailey

The piece of limb on which the bird stands is hollowed out and supplied with running water from a small pipe. It was constructed to attract birds.

\section{Chat, Yellow-breasted (Icteria virens virens)}

A bird that is averse to being seen. The chat prefers thickets of shrubs, vines and young saplings, situations midway between woodlands and open fields. It is the largest of the warblers and is quite unlike the rest of the family in some of its strange habits. It is the shyest and most difficult to photograph of any bird in the State.

Nu ChY1 Adult Female at Ease on a Post. Ithaca. (June 26, 1916)

Note the rather heavy warbler bill.

Allen

Nu ChY3 Nest with Four Eggs. Ithaca. (June 20, 1916) Allen

Nu ChY4 Female Incubating. Ithaca. (June 20, 1918) Allen

Nu ChY5 Adult Female with Food before a Young Bird. Ithaca. (June 26, 1918)

Allen

Note the wrenlike position of the tail. The bird, naturally shy, is here alarmed.

\section{Chickadee (Penthestes atricapillus atricapillus)}

The chickadee, a permanent resident in New York, is one of the most fearless of birds, particularly in winter, when it is common near houses. In the spring and during the summer it goes to the swamps and woodlands. It is restless, passing constantly from twig to twig. It flies with a jerky movement. It is sociable, usually traveling in company with a party of several birds. This bird is also known as black capped titmouse.

$\mathrm{Nu} \mathrm{Ci}$ Adult Feeding on Suet Placed on Side of Tree Trunl. Geneseo. (March 1906)

Bailey

During the winter time the chickadee will eat suet that is placed for it in convenient spots. It sometimes breeds close to the places where it is fed. Note the adaptation of suet and oily seeds to a winter diet. 


\section{Chickadee (continued)}

Call no.

$\mathrm{Nu} \mathrm{Ci} 2$ Adult at Entrance to Nest in Hollow of an Ailanthus Stub About Two Fect from the Ground. Ithaca. (May 29, 1915)

Allen

$\mathrm{Nu}$ Ci3 Nest with Eight Eggs in Hollow of Tree. Geneseo, (May $28,1910)$

Bailey

Notice the amount of lining in the nest, which is composed of grass, feathers, hair, moss and plant down. This nesting site was the winter home of a downy woodpecker the year before. There being no good standard of measure in view, the picture is apt to leave the impression that the eggs are larger than their actual size, the diameters of which are given by Eaton as .60 by .47 inches.

Nu Ci4 Brood of Nine Young, Posed in a Row on a Perch. Chapman

Do they resemble their parents?

$\mathrm{Nu} \mathrm{Ci6}$ Adult at Entrance to Nest in Stump; Food in Mouth for Young. Genesco. (May 1905)

Bailey

The nest of the chickadee is commonly in a small cavity of a dead tree near the ground. In this case it is in a deserted downy woodpecker's home. The food of the chickadee during the nesting season is mainly caterpillars. Note the string that holds the old stump together. The nest was exposed in making $\mathrm{Nu} \mathrm{Ci3}$.

Nu Ci8 Adult Pecking a Kernel under Its Foot. Ithaca. (March 20, 1915)

Allen

The chickadee does not swallow large pieces of food. Holding a kernel under one foot, he hammers it into pieces.

Nu Ci82 Adult at a Window-box. Ithaca. (March 25, 1915) Allen

The box protects the food from the snow. The birds do not mind the wooden sides of the box. The back is made of glass to admit plenty of light. Note how the frame is attached to the window casing. Many different species of birds will feed at such a box. The evergreen boughs are nailed beside the box to advertise it to the birds. 
Call no.

\section{Chickadee (continued)}

Nu Ci84 Chickadee and Junco at "Hood." Ithaca. (Jantary 1914)

Such a hood is an attractive feeding shelf. It is made of the top of a barrel, hoops and a piece of cloth, covered with evergreens and placed on a post.

Nu Ci86 Adult Perched on the Hand of Prof. Arthur A. Allen; String Connected with Camera. Ithaca. (December 31, 1913)

This picture shows the comparative friendliness of the chickadee. Note what kindness to the birds will do for the bird student. Professor Allen made this picture by pulling the string in his left hand.

$\mathrm{Nu}$ Ci88 Adult Taking Food from the Hand of a Lady. Ithaca. (February 1916) Allen

Chickadees are the most easily tamed of all of our native birds.

Nu Ci9 Chickadce and Junco on End of Old Log. Ithaca. (January 1914) Allen

Our native birds seldom feed together. Here the chickadee is eyeing the junco preparatory to snatching some food while the junco's back is turned.

$\mathrm{Nu} \mathrm{Ci} 94$ Chickadee and Female House Sparrow on Feeding Station. (February 1914)

Allen

The chickadec has stepped in to snatch a piece of peanut while another bird is present. The sparrow in this case makes no cflort to drive him away.

Nu Ci96 Adult on Sunflower. Ithaca. (August 4, 1917)

Allen

Use this picture to emphasize the fact that while this species usually retreats to the woodlands and swamps as summer approaches yet some representatives remain near habitations. 


\section{Coot (Fulica americana)}

Few birds have so many different names as the American coot. It is known as mud hen, water hen, crow bill, crow duck, blue peter and white-billed water chicken. It has still other names.

It is shot as a game bird, but its flesh is inferior to that of ducks. For this reason many persons do not shoot them. It is most numerous during the fall and spring.

$13-16$

Call no.

Nu $\mathrm{Cn}_{\mathrm{n}}$ Adult (captive) on Plank. Ithaca. (June 25, 1918) Allen

This and the captive ducks of this collection photographed by Doctor Allen were kept by him in captivity at his "Glenside" home to be released, banded, in his experimental studies of the migration and other habits of ducks.

$\mathrm{Nu}$ Cn2 Nest with Ten Eggs in Reeds. Renwick swamp, near Ithaca. (Junc 1, 1906) Bailcy

The nest is made of reeds and flags near the ground. It is placed in a cover of reeds. The eggs are similar to the gallinules, but the spots are smaller and blacker.

\section{Cowbird (Molothrus ater ater)}

The name cowbird was given this bird probably because it follows the cattle in the pasture and feeds on insects that are found on them. Cowbirds reach New York State from the south in March. The species is polygamous and polyandros. Unlike most other birds it never builds a nest but depends upon the labor of other species for nest building, incubating eggs and rearing young. It usually lays its eggs in the nests of the smaller birds. When these eggs hatch in advance of the other eggs, the young cowbird, being larger, gets most of the food brought by the old birds and the rightful young are starved. So each cowbird that matures usually means the death of four or five other birds that might have lived. Now and then a cowbird lays its eggs in the nests of birds larger than itself and then it may be the young cowbird that is starved. On account of its food habits it is counted a beneficial bird, but its parasitic nature is certainly not commendable.

$7.25-8.25$

Nu Co Adult Male (right) and Female (left) Feeding. Ithaca. (May 2, 1914) Bailey

The cowbird is attracted to such a feeding station by various sceds. As it builds no nest of its own, it can not readily be 


\section{Cowbird (continued)}

photographed at the nest. Note the shape of bill that puts it in the blackbird family.

Sce cowbird's eggs: In nest of indigo bunting

" chipping sparrow

" chipping sparrow

" field sparrow

" field sparrow

" wood thrush

" veery

" blue-headed vireo

" blue-headed vireo

" red-eyed vireo

" water-thrush
$\mathrm{Nu}$ BuI4

$\mathrm{Nu} \mathrm{SpC2}$

$\mathrm{Nu} \mathrm{SpC3}$

$\mathrm{Nu} \mathrm{SpF} 2$

$\mathrm{Nu} \mathrm{SpF} 3$

$\mathrm{Nu}$ TiW2

$\mathrm{Nu} \mathrm{Ve} 2$

$\mathrm{Nu} \mathrm{ViB} 2$

$\mathrm{Nu} \mathrm{ViB3}$

$\mathrm{Nu}$ ViR2

$\mathrm{Nu} \mathrm{Wf} 2$

Call no.

Nu Co4 Young Bird in Chipping Sparrow's Nest. Onondaga Valley. (1903)

Bailey

Note size of bird compared with that of nest.

Nu Co44 Young Bird in Red-eyed Vireo's Nest. Cardiff. (1909)

The young vireos have bcen crowded out of this nest and the cowbird is the sole survivor. Note that the relatively large cowbird completely fills the nest.

The red-eyed vireo is frequently selected by the cowbird to incubate its eggs and rear its young.

This is an unusual site for a red-eyed vireo nest, as an evergreen is seldom selected.

See also young cowbird in blue-headed vireo's nest $\mathrm{Nu}$ ViB4

See young cowbird being fed by a female redstart $\mathrm{Nu}$ Rf5

See young cowbird being fed by a chipping sparrow $\mathrm{Nu}$ SpC6

Nu Co8 Female Cowbird and Three Female House Sparrows Feeding on Old Log. Ithaca. (May 6, 1914) Allen

Cowbirds often associate with flocks of sparrows. Which is the cowbird? 


\section{Creeper, Brown (Certhia familiaris americana)}

The brown creeper is the only representative of its family in New York. It is a transient in most parts of the State and is an abundant summer resident in Potters swamp, Tonawanda swamp, the Catskills and the Adirondacks. It is comparatively approachable. It alights on the base of a tree and ascends in a spiral course.

$5.25-5.75$

Call no.

Nu CsB Adult on Trunk of Tree. Genesco. (1911)

Bailey

In the spring and fall the brown crceper may often be seen gleaning insects from tree trunks. It holds its tail against the tree much as woodpeckers do. The principal color of the bird closely matches the bark of the tree. It feeds sparingly on suet. The bird is rather smaller than one would infer from the picture. This tree is on a lawn, the grading of which has partly covered the base.

Nu CsB2 Clarence F. Stone Inspecting Nest under Bark of Tree. Potters swamp, Branchport. (May 20, 1915) Burtch

The nesting site is typical. The nest is usually less than five feet from the ground; it is composed of bark strips, hairs, rootlets and bits of cocoons placed under a piece of bark hanging loosely to the tree.

\section{Crow (Corous brachyrhynchos brachyrhynchos)}

The crow breeds in every county of the State and remains through the winter in the coastal district, the Hudson valley and the lowlands of western and central New York. It has a tendency to gather in roosts in winter; sometimes from 20,000 to 40,000 congregate and remain in a place.

The crow is one of the worst enemies of birds' nests and fledglings and has a reputation for destroying the farmer's corn. On the other hand it feeds upon an immense number of cutworms, beetles and other insects injurious to crops.

$17-21$

Nu Cu5 Adult at Nest with Three Young Birds. Geneseo. (May $15,1910)$ Bailey

In what kind of a tree is this nest? The crow is exceedingly wary and difficult to photograph. 
Call no,

\section{Crow (continued)}

$\mathrm{Nu}$ Cu2 Tall Tree with Crow's Nest

The nest is madc of sticks and bark in trees from 10 to 40 feet from the ground, sometimes as much as 80 feet.

Nu Cu3 Nest with Six Eggs in Tree, Secn from Directly Above. Near West Hills, L. I. (April 18, 1909) Harper

This nest was 40 feet from the ground. Note its size and composition.

Nu Cu4 Five Young Birds in Nest, Newly Hatched

A characteristic pose when the adults are approaching the nest with food. Notice the "pin feathers."

Nu Cu46 Three Young Birds (feathered) Resting in the Nest. Geneseo. (May 15, 1910)

Bailey

While the adults are away foraging for food the young usually remain quiet in the nest, thus lessening the danger from predacious animals.

Nu Cu6 Young Bird About a Week Out of the Nest, Side Vicw. Meridian

Tabor

This picture gives a characteristic pose. Note the light eye. Young crows have light blue eyes which change to gray and finally to brown. Note bristles at base of bill.

Nu Cus Flock Feeding near House in Winter. (March 3, 1914)

All'n

Even the wary crow will come to a feeding station during severe winter weather. Here the crows have come to some refuse that has been thrown out for them. They are valuable as scavengers.

$\mathrm{Nu}$ Cu84 Tracks in Snow. Ithaca. (January 1918)

Allon

Note dragging of feet, the close approximation of front toes and the length of the hind toc. Compare with tracks of phcasant, Nu PjR8.

Nu Cu9 Children and "Jimmie" Crow. Ithaca. (June 1917) Allen

This crow was a family pet for over two years. It learned to talk and to do many funny tricks.

For crows with herring gulls, see $\mathrm{Nu}$ GvH1. 


\section{Cuckoo, Black-billed (Coccyzus crythrophthalmus)}

The cuckoo is named from the song of its European cousin, the song of the American species in no way resembling the word. It is found in woods and swamp land. It is wholly beneficial. Caterpillars are its principal food, tent caterpillars and other web worms being its favorites when these are available. Its call, peculiar flight and extra long tail are means of locating and identifying it.

$11.5-12.7$

Call no.

Nu CvB2 Nest with Four Eggs. Geneseo. (June 1915) Bailcy

The cuckoo builds a slovenly nest which many times fails to hold the young and many are killed by falling out and starving. It secms to be true that it is growing more carcless in nest building and occasionally builds no nest but, like the cowbird, lays its eggs in the nests of other birds. Robins and bronzed grackles are said to be imposer upon, but more often it is one of their own kind. The nest is crudely built of sticks but there is some lining.

$\mathrm{Nu}$ CvB3 Adult on Nest Facing Observer. Near Syracuse. (Junc . 1911)

Bailey

With the cuckoo the feathers remain inclosed in sheaths until fully formed, when the transformation to a normally feathered bird occurs within a few hours. Note the black bill and red eye-ring.

Nu CvB4 Nest in Maple Sapling, with Threc Eggs of the Blackbilled and One of the Yellow-billed. Tully. (July 4, 1917)

Bailey

The yellow-billed egg is larger and whiter than the others.

Nu CvB5 Nest with Two Eggs and One Young Bird. Meridian

The nest sometimes, as here, contains eggs and half-fledged young, because the eggs are not laid regularly one each day, as with most birds. 


\section{Cuckoo, Yellow-billed (Coccyzus americanus americanus)}

Fairly common in the southern and central portions of the State but entirely absent from the Adirondacks and the Catskills.

$11.5-12.7$

Call no.

Nu CvY5 Adult with Caterpillar in Bill on Perch with Young Bird. Ithaca. (June 10, 1915)

Allen

The old bird has brought a tent caterpillar for the young bird, the cuckoo being one of the few birds that destroy this pest. Different from most young birds, the cuckoo after leaving the nest makes no show of excitement when the old birds come with food. Note the shape of the bill and the arrangement of toes.

Nu CvY6 Young Birds in Nest. (June 23, 1916)

Bailey

The feather sheaves, "pin feathers," are just beginning to break open.

\section{Dove, Mourning (Zenaidura macroura carolinensis)}

The mourning dove is the only wild pigeon found in New York State today. This bird is a relative of the extinct passenger pigeon, which it resembles closely. It feeds upon grain and weed seeds. The name is given it because of its weird and mournful call.

11-13

Nu DoM Adult Perched on Fallen Trce (a fceding station), Full Side View. (September 1914)

Bailey

Note the slender bill swollen at the base and the small feet, characteristic of pigeons.

Nu DoM2 Nest with Two Eggs on Limb of Evergreen Trec. Ingham co., Mich. (April 15, 1898)

Hankinson

The nest is poorly built of twigs, grass and vegetable fiber, a few feet from the ground. In this case it has been built on an old robin nest, a few twigs and rootlets having been added to the lining.

Nu DoM3 Female Incubating. Cardiff. (1910) Bailey

In what kind of a tree? Time of year? Note apple.

Nu DoM4 Two Young Birds in the Nest. Cardiff. (1910) Bailey Note the crudeness of the nest. 


\section{Dove, Mourning (continued)}

Call no.

Nu DoM5 Two Young Birds Just Able to Fly, Perched on Stub of

Limb. Geneseo. (1910)

Bailey

The young birds will pose, as shown in the picture, for a long time, waiting for the return of the adult. They are fed about once an hour with partially digested food. Do they resemble their parents?

\section{Duck, Black (Anas rubripes)}

This species is the commonest of the river ducks of the State. It breeds sparingly throughout the State, chiefly in northern portions. In the spring and fall this duck is found in small flocks about the central lakes of New York. The black duck is similar to the female mallard. How are the two species distinguished?

20-25

\section{Nu DuB2 Female on Nest on Ground}

Nu DuB8 Flock of About 130 Flying Overhead. Near Mastic, L. I. (September 1, 1912)

Harper

Owing to the protection given by the abolition of spring shooting, black ducks in recent years have begun to spend the summer in large numbers on Moriches bay. A part of a large flock is here shown swinging over the brackish meadows bordering the bay. Note the short tail, the long neck held straight out and the relatively long wings as compared with canvasbacks and scaup ducks.

See also $\mathrm{Nu} \mathrm{Ca} 92$ and $\mathrm{Nu}$ DuS7.

\section{Duck, Scaup (Marila marila)}

Other names of this duck are the bluebill, broadbill and blackhead. It is a transient, found chiefly along the coast and large inland waters. It breeds far to the north and migrates in winter sometimes as far as South America.

$18.5-20$

Nu DuS Single Adult Male on Water near Ice

Stone

The presence of ducks on our lakes and streams in winter depends partly upon there being open water. They do not remain where the surface is entirely frozen over. This bird was doubtless weak from lack of 'food and allowed a very close approach. The white flank feathers ordinarily conceal most of the wing. The thin neck and head thrown back on the shoulders are also signs of ill health. Compare $\mathrm{Nu} \mathrm{DuS5.}$ 
Call no.

\section{Duck, Scaup (continued)}

Nu DuS5 Flock on Water, Four Males and Four Females. Cayuga lake. (March 13, 1914)

Allen

The males have white flanks; the females are brown with white about the bill.

Nu Dus7 Flock in Flight Low over the Water. Cayuga lake. (March 13, 1914)

Allen

This is a characteristic scene on Cayuga and the other central lakes in winter. Note the relatively short wings of these diving ducks and compare with those of the black ducks representing the dabbling or river species.

Nu DuS8 Flock on Stream Taking Food from Person Seated on Shore. Ithaca. (March 22, 1914) Allen

These ducks became fairly tame from frequent feeding. They ventured well up into the city of Ithaca.

Nu DuS9 Four Birds in Speedy Flight over Wooden Decoys. Long cove, Great South bay. (April 2, 1911) Harper

The nearest three are females, as shown by the white patches on the side of the face. Great South bay is a favorite feeding ground for these birds in the fall, winter and spring. Note how the toes are spread and used as rudders, taking the place of the tail, which is very small.

\section{Eagle, Bald (Haliaetus leucocephalus leucocephalus)}

The bald, or American, eagle is the national bird. It is probably decreasing in number owing to the lack of nesting places and to the desire of many persons to have it mounted. Its place in the scale of bird life is that of a scavenger. Its food is largely dead fish. Now and then it robs the fish hawk of its captive prey. In New York it is now protected by law at all seasons.

ơ $31-34$; 오 $35-37$

Nu EB Adult in Flight Approaching Nest; Nest in Tree Top. Oneida lake. (1909)

Bailey

The nest of the eagle is built of sticks and is a massive structure. It is placed near the top of some high tree and is used 


\section{Eagle, Bald (continued)}

year after year. This particular nest was about 6 feet from top to bottom and about 5 feet across. There was a slight depression in the top. The habits of the bird lead it to add a few fresh sticks each year and at last the nest becomes so heavy that storms destroy it. This nest was blown out of the tree the fourth winter after this picture was taken.

Call no.

Nu EB1 Nest and Young Bird Flying from It. Oneida lake. (1911) Bailey

Notice the awkward position of the feet. The picture shows the first flight the young bird has ever attempted.

Nu EB3 Two Birds About Two Weeks Old Pcrched on Fallen Tree Trunk. Oneida lake. (1909)

Bailey

These birds were removed from the nest and placed on a limb for the purpose of photographing them. They are covered with a woolly down instead of feathers. After the pictures were taken the young eagles were replaced in the nest. Note the shape of bill, the powerful feet and the heavy wings.

Nu EB45 Two Young Birds in Nest. Oneida lake. (1909) Bailey

This picture was made in July, when the young were about four months old. They left the nest about two weeks later. The nest shown in the picture is only a few years old and consequently has not the vertical diameter shown in $\mathrm{Nu}$ EB.

Nu EB5 Young Bird Nearly Ready to Fly, Posed on Log, Back and Side Vicw. Oneida lake. (1911)

Bailey

Notice the position of the wings and the well-formed tail. The white head and tail of the adult do not appear until the second season.

Nu EB52 Young Bird Standing on Log, Showing Heavy Wings, Facing Observer. Oneida lake. (1909) Bailey

This bird at the age the picture was taken showed a remarkable development of wings, which were so heavy that the bird was obliged to let them droop. Such hastened development of wings is characteristic of the eagle and other soaring birds with large wings. 
Call no.

\section{Eagle, Bald (continued)}

Nu EB54 Eaglet Bristling, Side View. Bailey

Nu EB57 Head and Shoulder of Young Bird. Oneida lake. (1909) Bailey

Notice the strong curved beak for tearing flesh.

\section{Flicker, Northern (Colaptes auratus luteus)}

The flicker is known by several other names, as highhole, yarup and golden-winged woodpecker. It is a dominant species in New York and familiar to all. It is uniformly distributed in every county. It feeds on insects that it finds on the ground, especially ants, and is of positive economic good. While it eats wild fruits in the fall, it seldom troubles cultivated berries or fruits. It perches in a variety of places, including fruit trees, shade trees, roofs and telephone poles, and sometimes on the ground. "The undulating flight, conspicuous white patch on rump and the yellow of the wings which shows in flight are field marks which distinguish this species at a considerable distance."

$12-12.8$

Nu FkN Adult Female at Entrance to Nest in Tree Trunk. Arcade. (June 6, 1904)

R. H. Beebe

The opening is about $2 \frac{1}{2}$ inches in diameter. The hole extends downward 1 or 2 feet. It is considerably enlarged at the bottom. Study the arrangement of the toes and the position of the tail.

Nu FkN1 Adult Feeding on Suet Placed on Tree Trunk. Geneseo. (February 21, 1914)

Bailey

This bird was a winter resident during 1914 . The majority of flickers migrate.

Nu FkN3 Nest with Seven Eggs in Hollow of Tree Trunk. Onondaga Valley. (1908)

Bailey

The side of the trunk has been cut away to show where the eggs are laid. Note that no nest is built.

Nu FkN4 Four Large Young Birds Clinging to Side of a Stump

Bailey

These birds were placed where they are. Note how they instinctively cling to the vertical support. 
Call no.

\section{Flicker, Northern (continued)}

Nu FkN5 Six Young Male Birds Posed in a Row on Limb. Arcade. (1905)

Beebe

What distinguishes them as males? Flickers perch crosswise on a limb more often than other woodpeckers.

Nu FkN6 Adult Male on a Horizontal Perch, Side View. Geneseo. (January 1914) Bailey

Compare general shape of this bird with that of $\mathrm{Nu} F k N$. The flicker is a rather degenerate woodpecker.

Nu FkN8 Adult Flying to Nest Seen in Tree Trunk. Ithaca. (June 1,1915 )

Allen

Flycatcher, Acadian (Empidonax virescens)

Common in the lower Hudson valley, fairly common on western Long Island. It prefers dense woodlands in dry places.

$5.75-6.25$

Nu Fn1 Adult on Nest on Small Beech Limb. Taghanic. (June 11, 1913)

Allen

Note that the nest is semihanging.

Nu Fn2 Nest with Eggs

Bailey

Flycatcher, Crested (Myiarchus crinitus)

The brightest colored of the flycatchers. Courageous, making warfare on other birds. It prefers groves and forest. A common summer resident in all the warmer districts of the State.

$8.75-9.15$

Nu FnC Adult Leaving Nest in Hollow Tree Stub. South Onondaga. (1900)

Bailey

The head appears larger in proportion to the body than it really is because it is nearer the camera.

Nu Fnc2 Nest with Six Eggs in Cavity of Old Sawed-off Limb. South Onondaga. (1900) Bailey

The nests are placed in deserted woodpecker holes, cavities in limbs and sometimes in nesting boxes put up for the purpose. 


\section{Flycatcher, Crested (continued)}

Look for nest at height of 15 to 20 feet. The lining consists of wool, feathers, hair and usually the cast-off skin of a snake. This nest has been raised to the entrance to show the eggs.

Call no.

Nu FnC3 Nest in Cavity of Dead Tree, Torn Apart to Show Snakeskin in the Lining. South Onondaga. (1900) Bailey

Nu FnC4 Young Bird Just Able to Fly Perched on Limb. South Onondaga

Bailey

The pose is characteristic. Compare with that of the kingbird. Note what the perching attitude is. Note the broad flat bill.

Nu FnC5 Two Young Birds in Opening of Nesting Box, Parent Bird Near by on Branch

Note the characteristic pose of the adult.

See box inhabited by crested flycatcher, Nu ZB3, p. 154.

\section{Flycatcher, Least (Empidonax minimus)}

The least flycatcher, or chevec (spelled also chebeck), is a common summer resident of all parts of the State. It is found in gardens, orchards, groves and open woodlands. It is a beneficial bird, feeding largely upon flying insects of various kinds.

$5-5.5$

Nu FnL2 Adult on Nest on Branch of Apple Tree

Note cup shape of nest, also composition and structure. Compare position with that in $\mathrm{Nu}$ FnL4. Compare nest with that of the goldfinch.

Nu FnL4 Adult at Nest with Young in Apple Tree. Cardiff. (1910)

\section{Gallinule, Florida.(Gallinula galeata)}

Bailey

The Florida gallinule is more widely distributed throughout the marshy portions of the State than is generally supposed. It is known locally as the "water chicken." Like the rail, it skulks through the reeds in preference to flying. The Montezuma marsh is a favorite haunt. Several pairs nest at Dead creek near Baldwinsville. The swamps along Cayuga lake shelter a few pairs. 
Call no.

\section{Gallinule, Florida (continued)}

Nu GcF Adult Approaching Nest Filled with Eggs. Canoga, near Cayuga lake. (June 25, 1914)

Allen

Note relatively large number of eggs. Observe few white feathers on the flank. 'These feathers and others under the tail can be made conspicuous and are called "flash colors."

Nu GcF2 Nest with Ten Eggs in Reeds

Stone

The eggs are laid in May or June in a nest of reeds in the marsh. Note how the nest is built up from the water.

Nu GcF3 Adult Female Turning Over the Eggs. Canoga. (June 25, 1914)

Allen

Birds roll their eggs over regularly during incubation.

Nu GcF4 Adult Female Gradually Settling Down over Her Eggs. Canoga. (June 25, 1914)

Allen

Note how the feathers of the breast are being spread to bring the brood spots in contact with the eggs.

Nu GcF5 Adult Female on Nest Ruffling. Canoga. (June 24, 1914)

Allen

The feathers are ruffled to admit air and to keep the bird cool in the hot sun.

$\mathrm{Nu}$ GcF52 Young Hatching. Renwick, near Ithaca. (June 2, 1909)

Allen

Nu GcF6 Young on a Lily Pad. Renwick, near Ithaca. (June 2, 1909)

Allen

The young are covered with thick black down and can run and swim shortly after hatching.

Nu GcF7 Two Young Birds in Water, Stretching and Arranging Their Plumage. Branchport. (August 31, 1913) Burtch

The gallinule performs in this way after feeding. The attitudes are characteristic. The immature birds have lighter throats and under parts than the adults.

Nu GcF8 Young Bird Swimming Around in Shallow Water for Food. Branchport. (September 8, 1912) Burtch

This bird seeks food by the hour. It picks at the water weeds and sometimes draws them through its bill, probably for tadpoles and larvae of insects. Note the white under-tail coverts. 
Call no.

\section{Gallinule, Florida (continued)}

Nu GcF9 Young Bird Swimming in Shallow Water with Tadpole in Bill. Branchport. (September 7, 1913)

Burtch

When this bird caught the tadpole, several other birds immediately gave chase, but it managed to elude its pursuers and after several attempts swallowed its prize.

\section{Goldfinch (Astragalinus tristis tristis)}

A permanent resident, but not usually seen in the winter season. At this time it travels in flocks, changes its color and seems to avoid human habitations. It delays nest building until June or July and even as late as September. Other names for it are yellow bird and thistle bird.

$4.75-5.2$

$\mathrm{Nu}$ Go Adult Male on Sunflower. (August 4, 1914)

Allen

Sunflowers readily attract the goldfinch to the garden. This pose is characteristic.

Nu Go2 Female Incubating. Arcade. (1906)

R. H. Beebe

Note the type of nest. Of what is it composed?

Nu Go3 Nest with Eggs, Built of Corn Silk on Cornstalk. (September 1908)

Bailey

An unusual nest, built late in the season. As a rule the nest is made of vegetable down from milk weeds, dandelions or thistles. The nest is always well built and sometimes will hold water.

Nu Go4 Three Young Birds About to Leave the Nest. Chautauqua. (August 1910)

Allen

These birds outgrow the nest before they are fully ready to leave it.

$\mathrm{Nu}$ Go5 Adult Male on Branch near Nest with Young. Ithaca. (August 1, 1914)

Allen

The male helps the female in the care of the young. How do you know this bird is a male? 
Call no.

\section{Goldfinch (continued)}

Nu Go6 Adult Female on Limb Fecding Young. (August 22, 1914) Allen

The adult feeds all the young at each visit by regurgitation of seeds partially digested in its crop.

Nu Go7 Adult Female Standing on Nest with Young, One Bird Yct to Be Fed. Ithaca. (August 1914)

Allen

In what kind of a tree is this nest? The maple is more commonly selected.

\section{Goose, Canada (Branta canadensis canadensis)}

The best known of the New York waterfowls. While some of these wild geese remain within the State throughout the winter, their presence is looked for chiefly from October to December when they are migrating southward and again in March and April when they return to their principal home in Canada.

Nu GpC Eight Adults at Shore. North Bow pond, Geneseo. (April 2, 1915)

Bailey

Geese are among the first birds to arrive from the south. Where they find plenty of food, they remain for a month, as here.

Nu GpC6 Flock Swimming and Tipping, the Leader on Guard at the Shore. Geneseo. (April 2, 1915)

Bailey

These geese are exceedingly wary. Usually one of them is specially on guard for any sound or appearance that may bring harm. This picture was made from a blind.

These birds are feeding by straining out the grain from the mud on the bottom of the pond by means of their modified bill.

Nu GpC7 Flock in Flight in Typical V Formation. Geneseo. (April 1914)

Bailey

Wild geese usually migrate at a considerable height, the flock following a leader. The formation shown here is the common one. In which direction are these geese going?

Nu GpC8 Flock in Flight, Scattered Formation. Geneseo. (April 1915)

Bailey

Describe character of wing movement. This flock has just been frightened from its feeding ground and has not yet had time to get into the $\mathrm{V}$ formation. 


\section{Goose, Canada (continued)}

Call no.

Nu GpC9 Six Birds in Flight Seen Overhead. Gardiners island. (April 5, 1912)

Harper

These birds were flying about 100 feet from the ground. The flock is a small one in characteristic V-shaped formation.

Grackle, Bronzed (Quiscalus quiscula aneus)

This bird, known locally as the "crow-blackbird," is in illrepute among farmers because it "pulls corn." It also feeds upon the young of the smaller birds. It has been known to drive away song birds when they attempted to nest near its colony. It frequently associates with red-wings and cowbirds. All in all the bird is probably more destructive than beneficial, although it feeds upon many damaging insects. It is a common summer resident in western and central New York. It belongs to the Mississippi valley rather than to the Atlantic coast, where it is replaced by the purple grackle.

o $13-13.50$; 우 $12-12.50$

$\mathrm{Nu}$ GrB Adult Female on Edge of Nest with Young. Montezuma. (June 22, 1914) Allen

The old bird is feeding grasshoppers to the young. Note the feather tracts on the young bird.

\section{Nu GrB4 Two Large Young Birds in Nest}

The nest is coarse and bulky. Of what materials is it made? The middle layer of mud does not show. The nest is similar to that of the robin but larger.

Nu GrB5 Large Young Bird on Limb, About to Fly. Dccorah, Iowa Compare with young crow.

Hegner

Nu GrB7 Adult Feeding on Crumbs on Ground. Geneseo. (1908)

Bailey

Notice how wary the bird is. He is alarmed by the shutter of the camera. Note the character of the bill. The tail, which is longer than in the other blackbirds, is not well shown in this picture. 


\section{Grebe, Holbcell (Colymbus holboelli)}

This is the largest of the grebes. Like other grebes it has broadly lobed feet for swimming. The tail is rudimentary.

Call no.

$\mathrm{Nu}$ GsH Adult in Winter Plumage, Standing in Water near Ice, Erect with Head Thrown Back. Arcade. (About 1905)

R. H. Beebe

Note the posterior position of legs. Compared with that of ducks and.geese. This bird stands nearly in a perpendicular position. When photographed it was in a weakened condition. The winter was severe and the streams and lakes were almost entirely frozen over. Large numbers of these birds perished at this time.

$\mathrm{Nu}$ GsH4 Immature Bird (a captive) Resting on a Table. (1910)

Bailey

\section{Grebe, Pied-billed (Podilymbus podiceps)}

Other names are hell-diver, dipper, diedapper and water-witch. This grebe may be distinguished from the others by its short, thick bill. Look for the black throat patch and band on the bill, distinctive marks during the breeding season. It is becoming less common as marshy ponds and streams are being drained and lakes are frequented by hunters and pleasure seekers.

12-14

$\mathrm{Nu}$ GsP Nest with Eggs, Adult and Young Swimming beside It. Michigan hollow, near Ithaca. (June 18, 1913) Allen

The nest is usually supported on submerged weeds or rubbish, but sometimes floats on the water, anchored to nearby stems. The young swim as soon as hatched.

Nu GsP1 Nest with Eggs, Typical Surroundings. Michigan hollow, near Ithaca. (June 18, 1913)

Allen

Note the comparatively exposed position. This grebe prefers shallow water. The eggs did not show until the photographer uncovered them.

Nu GsP2 Nest with Eggs Covered by Adult with Nesting Material. Michigan hollow, near Ithaca. (June 10, 1913) Allen

When this bird leaves its nest for forage or when it is frightened by the appearance of an enemy, it covers the eggs with material from the nest. Why? 
Call no.

\section{Grebe, Pied-billed (continued)}

Nu GsP3 Nest with Both Young Birds and Unhatched Eggs. Michigan hollow, near Ithaca. (June 18, 1914)

Allen

Notice the stripes on the young birds.

Nu GsP4 Adult Removing Eggshell from the Nest. Michigan hollow, near Ithaca. (June 18, 1913)

Allen

Note that the feathers on head and neck are wet and look like a crest.

Nu GsP5 Adult with Young Swimming. Michigan hollow, near Ithaca. (June 10, 1913)

Allen

How many young birds can be seen? The grebe is an easy swimmer. Find out how it dives.

Nu GsP6 Young Bird Swimming. Michigan hollow, near Ithaca.

(June 18, 1913)

Allen

Note that the young grebe is striped, differing greatly in appearance from the old bird. It is covered with down like young ducks, but has the characteristic lobed toes of the grebe family, colymbidae, with legs at the posterior end of the body.

$\mathrm{Nu}$ GsP8 Immature Bird in Water Picking Its Foot. The marsh at Branchport. (September 8, 1912)

Burtch

When these birds are undisturbed, they spend much time cleaning plants from their toes and shaking out their wings. The stripes on the sides of the head and the absence of black on the throat and bill indicate its immaturity.

\section{Grosbeak, Evening (Hesperiphona vespertina vespertina)}

The evening grosbeak is a somewhat irregular winter visitant. It nests in western Canada and migrates south and east, coming to New York irregularly and infrequently, usually during severe winters. Its food is mainly buds and fruit of box-elder, choke cherry and mountain ash. In 1914 a flock of a score or more came to Ithaca and were led to feed upon sunflower seeds. The following pictures were secured at that time. The birds were induced by abundant food to remain until the middle of May. 
Call no.

\section{Grosbeck, Evening (continued)}

Nu GtE Adults, Male and Female, "Billing." Ithaca. (April 29, 1914)

Allen

Not a courtship performance but the beginning of a fight.

Nu GtE7 Adult Female, Back and Side View, at Feeding Station. Ithaca. (April 20, 1914)

Bailey

Notice the heavy beak for crushing seeds.

Nu GtE8 Adult Male Charging House Sparrow. Ithaca. (May 2, 1914)

Allen

The sparrow is so frightened that it is falling off the end of the $\log$.

Nu GtE9 Flock of Nine Adults, Male and Female, Feeding on Ground. Ithaca. (April 17, 1914)

Allen

Grosbeak, Rose-breasted (Zamelodia ludoviciana)

This grosbeak is much more common and more widely distributed than the evening. Its haunts are rich woodlands with good undergrowth, also swamps and streams lined with shrubs. It is a summer resident in New York State.

$7.75-8.5$

Nu GtR Adult Male at Nest Feeding Young, Seen from Above. Ithaca. (June 13, 1911)

Allen

The male shares with its mate various household duties.

\section{Nu GtR2 Nest with Four Eggs}

The nest is usually placed in an alder, maple, elder, beech or hemlock sapling or on a limb of a low tree. Study the location of the several nests shown in this group of pictures. Is the nest well constructed? Compare with that of catbird.

Nu GtR3 Adult Female Entering Nest, Four Eggs in Nest. Renwick, near Ithaca. (June 5, 1915)

Allen

She inspects the nest to see that all is right before taking her place upon the eggs.

Nu GtR4 Female Incubating. (June 5, 1915)

Allen

The female is more protectively colored than the male. The nest is often placed, as here, in an elderberry bush along the edge of a woods. 


\section{Grouse, Canada (Canachites canadensis canace)}

Other names are spruce grouse and spotted grouse. Confined in New York to spruce, fir and tamarack forests of the Adirondacks. It is becoming more and more scarce. Why? It is likely to become exterminated. It is unsuspicious, hence easily shot.

Call no.

Nu GuC Adult Perched on Old Upturned Roots

Stone

Note the henlike form-strong legs, short bill and short wings.

\section{Grouse, Ruffed (Bonasa umbellus umbellus)}

Commonly known as the partridge. This bird is ranked as the best game bird in the country. This means that it is a strong flyer and is able to outwit the hunter. Compare with the spruce grouse. Its flight is rapid, and its tendency to keep to the second growth makes shooting it in flight difficult. Rainy weather during May and June is destructive to the young grouse and when stormy springs follow one another for several years grouse become very scarce. It is then necessary to give them complete protection for several years that they may recuperate.

$16-19$

Nu GuR15 Female, Back View, on Ground in Woods. Geneseo. (March 24, 1919)

Bailey

Nu GuR2 Adult Incubating. Onondaga Valley. (1912) Bailcy

This particular nest was built near picnic grounds for children, and the bird became used to the noise and commotion caused by the children at play. As a result it was easy to approach her nest and photograph her at close range.

Nu GuR3 Nest with 15 Eggs under a Brush Pile. Cardiff. (May 1899) Bailey

Nu GuR4 Nest with Eggs under Rail Fence. South Hill marsh, Ithaca. (May 7, 1905)

Allen

This fence borders a wood lot. There are at least nine eggs in this nest. Often there are fifteen or more. With ordinary protection these birds would propagate fast enough to restock the covers without any aid from man. The destruction of natural cover in the woods compels this bird, at times, to seek the protection of fences and hedge rows. 
Call no.

\section{Grouse, Ruffed (continued)}

Nu GuR5 Young Just Hatched and Egg Shells in Nest. Ithaca. (May 26, 1905)

Allen

Note the regularity with which the eggs were opened by the young.

Nu GuR6 Young Bird Crouching among Leaves and Bushes, Michigan hollow, near Ithaca. (June 17, 1911) Allen

This bird is able to fly but prefers to depend upon protective coloration for concealment.

Nu GuR7 Adult Female Nearly Invisible in Brush and Other Vegetation. South Hill marsh, Ithaca. (June 1, 1905)

Allen

This grouse is very protectively colored and will allow close approach before flying. Many are passed unnoticed in the woods. Note how the color pattern of the back simulates that of its surroundings. This, together with its counter shading, makes the bird almost invisible.

Nu GuR1 Male Drumming on Log. Geneseo. (April 14, 1919)

Bailey

For an account of this interesting habit, see Eaton, v. 1, p. 369.

\section{Gull, Herring (Larus argentatus)}

The most common and widely distributed gull of New York. It is especially common along the coast and on the Great Lakes. On smaller bodies of water it is a transient visitor. It still breeds in the Adirondacks, but is becoming rarer. Why? It is valuable as a scavenger in cleaning up dead fish and refuse about harbors, lakes and shores.

$22.5-26$

Nu GvH Three Adults Standing on Newly Forming Ice. Branchport. (September 14, 1915)

Burtch

Herring gulls come here in September but are not common until cold weather. A few remain as long as there is open water. In April and May on return migration they again become common. 
Call no.

\section{Gull, Herring (continued)}

Nu GvH1 Flock of Herring Gulls and Crows Feeding on Snow. Ithaca. (March 4, 1914)

Allen

The streaks on the head and neck are worn only during the winter. Note shape of bill for tearing fish.

Nu GvH4 Three Young Birds Hiding beside a Rock. Near Parry sound, Georgian bay, Canada. (June 1911) Bailey

A good study in protective coloration. Notice the mottled appearance of the head.

Nu GvH7 Numerous Adults Soaring Overhead. Near Parry sound, Georgian bay, Canada. (June 1911) Bailey

Note the long, narrow wings for gliding. This photograph was taken against the sun and the light shines through the tips of the wing feathers.

Nu GvH8 Several Adults Flying over and Rising from the Water. Near Parry sound, Georgian bay, Canada. (June 1911)

Bailey

Notice the position of the wings and feet of the flying gulls. In the distance gulls are resting on the surface of the water. How can you tell that the gulls are rising rather than settling?

Nu GvH9 A Multitude of Gulls and Terns Flying over and Settled upon Nesting Island. The Limestones, near Parry sound, Georgian bay, Canada. (June 1911) Bailey

\section{Hawk, Cooper (Accipiter cooperi)}

The cooper is one of the most destructive of the hawks. It feeds almost exclusively upon small birds and poultry. It is a quiet, low-flying hawk and is seldom seen. The high-flying hawks, like the red-tailed and red-shouldered, are usually blamed for the damage that this hawk does. Because of the practice followed by farmers and others of destroying the nests, the species is becoming less common.

of 15-18; 아 18-20

Nu HC2 Adult, Front View, with Young, at Nest. Conesus lake. (1911) 
Call no.

\section{Hawk, Cooper (continued)}

Nu HC3 Nest with Five Eggs. Decorah, Iowa

Hegner

The nest is built in crotches of trees, usually high up; sometimes old crows' nests are used.

$\mathrm{Nu} \quad \mathrm{HC}_{4}$ Adult Tearing Up a Chicken, at Nest with Young. Conesus lake. (1911)

Bailey

\section{Hawk, Duck (Falco peregrinus anatum)}

The most dashing and skilful of all our hawks; sometimes called the noble falcon. It prefers mountainous districts and in New York occurs most frequently along the Palisades and in the Highlands and the Adirondacks. It strikes its prey while in midair. It has been known to kill the smaller ducks and pigeons and other birds.

$\delta$ about 17 ; $q 19$

Nu HD2 Adult and Eggs. Taghanic falls. (May 1913)

Britten

This hawk nests along ledges and usually selects inaccessible ones. The same site is used year after year. This one was known as early as 1909. No nest is built. Note the shape of the bill of the bird and also the powerful feet.

Nu HD3 Young on Nesting Ledge. Taghanic falls. (1913) Bailey

The birds are looking down 200 feet to the talus slope below. A misstep at this edge on the part of the photographer would be fatal. Sometimes the young birds fall from the ledge and are killed.

Nu HD4 Young Bird after Leaving Nest. Taghanic falls. (Junc 1913)

Bailey

From these stubs the young birds await the call of the parent with food. As soon as the parent starts toward the stub, the young fly out and take the food in midair. The young are more heavily streaked than the adults.

Nu HD5 Young Answering the Call of the Parent. Taghanic falls. (June 1913)

Bailey

Taken just before the bird left the perch for its food. 


\section{Hawk, Marsh (Circus hudsonius)}

This species is a resident of marshes and swamps, easily identified by its white rump in flight. It is abundant and breeds in every part of New York. It feeds largely upon mice, for which it watches while hawking. Its nest is built on the ground, which is unusual for hawks.

of 17.5-19; 우 19-22

Call no.

Nu HM Aduit Male at Nest in Cat-tails, Seven Eggs in Nest. Canoga, near Cayuga lake. (June 26, 1914)

Allen

The male is much lighter in color than the female. He sometimes assists in nest building, incubating and brooding, but more often assigns these duties to the female while he stands guard or brings her food. Note the typical hawk bill, feet and posture.

Nu HM2 Nest with Six Eggs. Clinton co., Mich. (May 22, 1897)

Hankinson

Nu HM3 Birds Seven Days Old, and an Egg. Hallock, Minn. (June)

Peabody

Young hawks are covered with down when hatched but, unlike precocial young, are helpless for a long time.

Nu HM4 Young Nearly Ready to Fly. Cardiff. (1911)

Bailey

The young birds are belligerent. They know no fear. They will throw themselves on the back and claw at any enemy, however large. The young birds are good flyers, but are unable to alight on a perch. 'They alight in the deep grass and can be caught by being rushed.

Nu HM5 Young Bird Posed on Post Just after Leaving the Nest. Cardiff. (1911)

Bailey

Note the slender legs and toes. Is the young bird colored like the male or the female?

Nu HM6 Male Perched on Stub. Canoga, near Cayuga lake. (June $25,1914)$ Allen

The marsh hawk seldom perches on trees as do other hawks, preferring to alight on the ground. About the nest, however, it usually chooses such a lookout as this one. 
Call no.

\section{Hawk, Marsh (continued)}

Nu HM8 Adult in Flight Approaching Stub. Canoga, ncar Cayuga lake. (June 25, 1914)

Allen

The wings of the marsh hawk are longer and narrower than those of the other species of hawks. The tail is spread to check the bird's momentum before alighting. Compare with $\mathrm{Nu}$ HM7.

Nu HM7 Adult in Flight, Seen from Below. Gardiners island, (Junc 17, 1911)

Harper

This hawk showed by hovering about and uttering its complaining cry that it had a nest not far away. This photograph was not taken during the molting season, but apparently the sixth primary of each wing has been lost.

\section{Hawk, Red-shouldered (Buteo lineatus lineatus)}

This hawk belongs in the helpful group, as it feeds upon destructive rodents. It is often mistaken for the red-tailed hawk, which it closely resembles.

o17.5-19; 우 19.5-21

Nu HP2 Nest with Four Eggs in Becch Tree. Cascadilla valley, near Ithaca. (April 30, 1910)

Allon

This nest is 40 feet from the ground. With what is it lined?

Nu HP4 Three Birds, 16-18 Days Old, on Ncst. Arcade. (June 3, 1905)

R. H. Beebe

When just hatched the red-shouldered hawks are covered with down and lack the fierce nature of their parents. In this picture the feathers are just coming through the down.

Nu HP5 Two Young Birds Perched on Old Log. Arcade. (1905)

R. H. Beebe

Inmmature red-shouldered hawks have white spotted breasts, but the adults have them uniformly rusty in color, more or less barred.

Hawk, Red-tailed (Buteo borealis borealis)

This hawk, one of the high-sailing type, is a most beneficial bird. Its food consists almost wholly of the destructive meadow mouse and the woodchuck. Though commonly known as the 


\section{Hawk, Red-tailed (continued)}

"hen hawk," it very seldom feeds upon birds or poultry. It should be protected. Some misguided persons assume that this hawk should be trapped because it feeds upon poultry. From time to time farmers' sons try this method of ridding the farms of these beneficial birds, believing them to be enemies of poultry. While poultry is fed upon by hawks, it is usually the cooper or the sharp-shinned hawk that is the actual culprit. 19-21; 22-24

Call no.

Nu HR Immature Bird Perched on Broken Limb of Tree. (1902)

This bird is probably watching for a mouse, a squirrel or a bird.

Nu HR2 Two Birds on Nest in White Birch Tree. Decorah, Iowa. (April 22, 1901).

Hegner

The nest is usually in the fork of a tall tree, maple, beech, elm, basswood, hemlock or pine, 40 to 80 feet from the ground. The same nest is occupied year after year. Study its composition and structure. The tail of the adult bird is red, but that of the immature is banded.

Nu HR4 Two Young Birds Removed from Nest and Posed on Fence Rail. Geneseo

Bailey

One of these birds was afterwards shot while it was feeding upon a woodchuck. The young hawks remain in the nest for some time after they are fairly good flyers. They are not independent of the adults until they are able to capture their own food. It takes a month or more for them to become skilful enough to catch live mice and woodchucks. Study the picture to determine which feathers are the last to push through the down of the young.

\section{Nu HR9 Male Perched on Stump over Traps Set for It}

Note the band of spots across the. breast, a good field mark.

\section{Hawk, Sparrow (Falco sparverius sparverius)}

A summer resident throughout the State and breeds in almost every community. In winter it is often found near cities and villages, where it feeds largely on English sparrows.

$10-11.5$ 
Call no.

\section{Hawk, Sparrow (continued)}

Nu HT Adult Female with Dead Sparrow. Genesco. (March 8, 1914)

Bailcy

The food of these birds consists of grasshoppers, dragon flies, meadow mice and now and then a young bird. The young birds are caught as food more often on cold mornings before the insects are active. During deep snow the sparrow hawk is often forced to come to buildings and hedges in pursuit of the English sparrow. At such times it will feed upon dead sparrows that may be fastened to a perch or thrown on the snow. This is a female, as shown by its streaked rather than spotted breast.

Nu HT3 Nest with Five Eggs in Abandoned Nest of Flicker in Old Stump. Ithaca. (June 2, 1916)

Allen

The nest is usually placed in a hollow limb, here as often in a deserted flicker's nest, occasionally in a box put up for the purpose. No nesting material is used. This nest is from 30 to 40 feet above the ground.

Nu HT4 Young Bird Posed on Percli, Profilc. Near Grecuridge, Staten island. (July 19, 1908)

Harper

This bird has been removed temporarily from its nest in the hollow of a large elm tree. It is not yet ready to fly, as shown by the down feathers on it. When the bird was photographed, it had already been long enough in confinement to lose some of its wildness.

Nu HT8 Adult Startled by the Click of the Shutter, Wings Raiscd. Geneseo. (March 8, 1914)

Bailey

Note the pointed wings characteristic of falcons.

Nu HT9 Adult Trying to Fly Away with Dead Sparrow. Genesco. (March 8, 1914) Bailey

Note the large stretch of wing.

\section{Heron, Black-crowned Night (Nycticorax nycticorax ncevius)}

This bird nests in colonies using, however, as a rule, a smaller tree than the great blue heron. From time to time single pairs may nest in the company of the great blue heron. Their feeding habits are much the same as those of the other herons.

23-26 
Call no.

\section{Heron, Black-crowned Night (continued)}

Nu HeB Two Adults Perched in a Dead Tree Top. Near Roslyn. (June 9, 1907)

Harper

These birds belonged to a large colony. They were about 60 feet from the ground. While being photographed from a neighboring tree they showed little fear.

Nu HeB1 A Heronry. Near Roslyn. (April 19, 1908)

Harper

Hundreds of black-crowned night herons formerly bred here. The several nests seen in the tops of the swamp maple trees are those of the previous season. The birds in April were just returning to build new nests or occupy the old ones. A few years later this colony was abandoned by the birds, probably owing to persecution.

Nu HeB2 Several Nests in Swamp Maple Tree

The size of the nests can be judged by the crow in the tree.

Nu HeB3 Nest with Four Eggs. Long Branch. (May 31, 1914)

Bailey

Note that the nest is composed entirely of sticks and has no lining.

Nu HeB5 Immature Bird in Flight. Near Roslyn. (July 18, 1908)

Harper

By July 18th most of the young birds of the season are on the wing. This bird was photographed from the top of a tree as it flew over the heronry. The plumage is streaked brown, quite different from that of the adult and very similar to the bittern.

\section{Heron, Great Blue (Ardea herodias herodias)}

This heron is a transient visitant in all parts of the State and a summer resident in several localities. It is a large, attractive bird. It is occasionally destructive to trout, but more often to other fish of little value upon which it feeds, its long beak being used to spear the fish.

$42-50$

Nu $\mathrm{HeF}$ Adult in Feeding Ground. (1898) 


\section{Heron, Great Blue (continued)}

Call no.

Nu HeF1 Three Adults Perched near Nests on Limbs of Tall Tree. Oneida lake. (1909)

Bailey

These birds nest in colonies high up in tall trees. The Oneida lake colony has more than a hundred nests in a small area. The food of these birds consists of fish, frogs and tadpoles. Notc structure and composition of nest.

Nu HeF2 Three Young Birds in Nest. Oneida lake. (1911) Bailey

Notice the resemblance between the sticks and the necks of the birds. Note that the nest is not kept clean like those of most birds.

Nu HeF3 Young Birds Removed from Nest and Posed on a Fallen Tree Trunk. Oneida lake. (1909) Bailey

This bird, like many others, gains the use of legs and wings slowly. The young are awkward looking. Compare the birds here shown as to position.

Nu HeF44 Two Young Birds Perched on a Limb. Tonawanda swamp. (1907)

R. H. Beebe

Note long legs and neck to match, also long toes and javelinlike bills.

Nu HeF6 Immaturc Bird Wading in Scarch for Food. From negative in collection of A. W. and Julian A. Dimock. Florida

Note where this bird was photographed. Consider how nature adapts each bird by its structure for its peculiar life. The dark crown is characteristic of an immature bird.

Nu HeF7 Adult (wounded) on Water near Stump. Branchport. (April 12, 1914) Burtch

This bird had been caught in a steel trap and had lost a toe. Unless bathing or wounded, a heron would not sink thus far into the water. Note the white crown of the adult.

Nu HeF8 Immature Bird Advancing Carefully through Shallow Water and Vegetation. Branchport. (August 24, 1913) 
This bird is looking for fish and advances very carefully. When it has seen its victim, it moves its head slowly until within striking distance, then suddenly plunges it into the water. If a small fish or frog is gotten, it is swallowed at once. A larger one is carried to solid ground and pulled into pieces.

\section{Heron, Green (Butorides virescens virescens)}

Other names are fly-up-the-creek and shitepoke. It is the most familiar heron in most parts of New York. It is found along small streams and ponds as well as larger lakes and swamps.

Call no.

$15.5-22$

Nu HeH Adult on Branch near Nest; Nest with Egg and Young. (June 15, 1914) Allen

Like the bittern, the heron often draws the neck back so it appears shorter than it actually is. Note bill, legs and toes.

Nu HeH2 Nest with Five Eggs. Meridian

Tabor

The nest is a slovenly made structure of sticks, so loose that the eggs may sometimes be seen through the bottom.

$\mathrm{Nu} \mathrm{HeH} 3$ Adult Incubating. Michigan hollow, near Ithaca. (June $15,1914)$

Allen

This bird seldom nests in colonies like the great blue heron but usually singly in low trees and sometimes in bushes over the water. Observe of what coarse material and how carelessly the nest is put together.

$\mathrm{Nu} \mathrm{HeH} 4$ Three Young Birds in Nest. Meridian

Tabor

They have not learned fear.

Nu HeH5 Three Young Birds Taken from the Nest. (1899)

Notice the tendency of these birds to point their necks straight up. This is a characteristic of them whenever they are frightened.

$\mathrm{Nu}$ HeH6 Young Bird Swimming among Reeds. Michigan hollow, near Ithaca. (July 4, 1913)

Allen

The bird is not precocial but is swimming freely, although still in down and quill feathers. Although altricial, young herons gain their strength more quickly than their feathers and climb from the nest long before they fly. 
Call no.

\section{Heron, Green (continued)}

Nu HeH8 Adult Flying over Swamp. Montezuma. (September 1910)

Allen

Note the closeness of the primaries on the downward stroke of the wing.

\section{Hummingbird, Ruby-throated (Archilochus colubris)}

Found in all parts of New York, both the more thickly settled and the dense forest regions. The only species of this family in eastern United States. It flies from flower to flower for the nectar and also for small insects attracted to the flowers by nectar.

구 3.5 ; 오 3.85

Nu HuR Adult Hovering before a Flower on Which Rests a Butterfly

Chapman

Note how it sustains itself in one position before the blossom. The rapid movement of the wings is too fast for the camera to catch. What is the position of the tail?

Nu HuR2 Nest with Two Eggs, Seen from Directly Above. Meridian

Tabor

The nest is beautifully constructed of lichens and spider webs, usually on top of a limb. The eggs are about the size of small beans, nearly elliptical and always two in number.

Nu HuR3 Female Incubating

Chapman

In judging size of bird and nest note apple and leaves.

Nu HuR4 Adult Female on Edge of Nest

Chapman

How can you tell it is a female? Note the long slim bill.

$\mathrm{Nu}$ HuR5 Adult Feeding Young in Nest. Ithaca. (July 2, 1915)

Allen

The bill of the old bird is inserted far down the throat of the young and nectar and small insects are pumped into it. 


\section{Jay, Blue (Cyanocitta cristata cristata)}

One of the most beautifully colored of our birds, but a nest robber and noisy. It stores food, such as acorns and beechnuts, and hides it away for use in the winter season. In New York State it is rather uncommon around habitations and keeps to the woods, while in the mid-west it nests in the trees of villages and towns.

$11-12.5$

Call no.

Nu JB8 Adult on Nest, Tail Raised, Seen from Side and Above. Arcade. (1905)

R. H. Beebe

Note the thick bristles at the base of the bill.

Nu JB4 Three Young Birds on Branch of Apple Tree, Just after They Left the Nest. (July 1912)

The blue of the mature bird does not yet show fully.

Nu JB6 Adult on Limb. Arcade. (1905)

R. H. Beebe

Note the crest, the heavy bill and the basal bristles.

Nu JB7 Adult on Nest in Small Hemlock Tree, from in Front and Above. Letchworth park. (June 2, 1914)

Bailey

Observe whether an evergreen tree is usually selected as the nesting site. Note how the breast feathers are ruffled out to bring the breast in direct contact with the eggs.

\section{Junco, Slate-colored (Junco hyemalis hyemalis)}

One of our common winter birds, especially in the southern portion of the State. Known also as the snow bird. It generally migrates farther north in summer but individuals remain throughout the colder portions of the State, especially the Adirondacks and Catskills. It is easily recognized by the two white outer tail feathers. It is a valuable bird because of the large number of weed seeds it destroys.

$6.2-6.4$

$\mathrm{Nu}$ JuS Adult at Feeding Station, Side View. Geneseo. (April 9, 1912)

Bailey

$\mathrm{Nu}$ JuS2 Nest with Four Eggs on Ground among Bunchberry Plants. C. Will Beebe

The eggs are three or four in number. The bunchberry is a northern plant. 
Call no.

\section{Junco, Slate-colored (continued)}

Nu JuS6 Adult on Nest in Tall Lodged Grass. Cranberry lake. (June 28, 1916)

Bailey

Nu JuS8 Junco Driving Nuthatch Away from Feeding Station. (January 1914)

Allen

Nu JuSg Flock at "Glenside" in Snowstorm. Ithaca. (April 1918)

Allen

Glenside is the home of $\operatorname{Dr}$ Arthur A. Allen, who has about the house several acres of glens and wooded hillside, a veritable bird retreat, near the campus of Cornell University. This picture illustrates when the birds need to be furnished with food.

For junco at feeding station with chickadee, see $\mathrm{Nu} \mathrm{Ci9}$.

\section{Killdeer (Oxyechus vociferus)}

The name killdeer is from its call, which can be heard at its first arrival in the spring and night and day throughout its season. A familiar bird in cultivated fields, where it runs about on plowed ground feeding upon many kinds of insects. This bird is now protected and is no longer a game bird.

9-11.5

Nu Ke2 Adult over Eggs on Plowed Ground. Geneseo. (1910)

Bailey

Note how the white rings and black bands, called "ruptive marks," seem to cut the bird into several pieces. Note how the breast feathers are being spread to expose the brood spots and bring them against the eggs.

Nu Ke3 Nest with Four Eggs. Near Branchport. (July 8, 1915)

Burtch

This nest was found by a farmer while cultivating corn. $\mathrm{Mr}$ Burtch reports one killdeer that laid a third set of eggs in a cornfield after the first two had been destroyed by the cultivator. Observe the circle of pebbles picked out by the bird in making the depression into which the eggs are laid. Are the eggs protectively colored?

Nu Ke4 Female Incubating. Arcade. (1906)

R. H. Becbe

$\mathrm{Nu}$ Ke5 Three Young and an Unhatched Egg in Nest. Arcade

R. H. Becbe

This is a good example of protective coloration, both in the color pattern and ruptive marks. The young are crouching, the fear instinct developing early in precocial birds. 
Call no.

\section{Killdeer (continued)}

Nu Ke7 Adult Brooding. Cascadilla valley, Ithaca. (April 30, 1910) Allen

The young birds have run beneath the old bird's wings.

The bill of plovers is much shorter than that of sandpipers.

Nu Ke8 Adult Feigning Distress near Nest. (May 1907) Allen

Nu Ke9 Adult on Wing. (April 30, 1910) Allen

The wings are long and pointed. The killdeer is very swift on the wing.

\section{Kingbird (Tyrannus tyrannus)}

A common summer resident of New York, widely distributed and usually found in orchards, pastures and roadsides. It is one of the flycatchers and feeds upon beetles, bees, grasshoppers, moths and other insects. This bird will attack and drive away a hawk or a crow.

8.4-8.75

$\mathrm{Nu}$ Kh Adult on 'Twig near Nest, Front View. Cardiff. (1910)

This nest with young birds was removed from the top of a tree and placed as shown in the picture. The adults continued to feed their young regularly as if the nest were in its natural place.

Nu Kh2 Adult on Twig near Nest, Side View. Cardiff. (1910)

Bailey

The bird here has a honey bee in its mouth. Some beekeepers believe that kingbirds feed upon the workers, but examinations of the birds' stomachs show that the bees the birds feed upon are largely drones. Note the erect posture. Most flycatchers perch even more erect.

Nu Kh5 Three Young Birds Placed on Twig, Adult Female Perched near Them. Arcade. (1906)

R. H. Beebe

The white band on the end of the tail is a good field mark. 


\section{Kingfisher, Belted (Ceryle alcyon)}

This bird is found throughout the State along lake shores, rivers, ponds and brooks.

$12.5-14.75$

Call no.

Nu KiB Adult Female Perched on Stick Stuck in Bank, Front View. (June 3, 1914)

R. H. Beebc

The stick is placed directly before the nest hole. The male does not have the brown band across the breast so that in this respect the female is brighter than the male.

\section{$\mathrm{Nu}$ KiB2 Nest with Seven Eggs in Sand Bank}

The eggs of the kingfisher are laid at the end of a burrow dug in a sand or clay bank by the bird. This tunnel is frequently three feet long. At the farther end it is enlarged and from five to eight glossy eggs are laid. The entrance to the nest here shown has been cut away. No nest is built.

Nu KiB3 Birds Two Days Old. (May 21, 1899)

W. L. Baily

The young are hatched naked, blind and helpless. The down found on most altricial birds is lacking.

\section{Nu KiB4 Birds Nine Days Old}

Here the eyes are opened and pin feathers are developed. The developing feathers, "pin feathers," remain in the sheaths until full grown, when they burst and the transformation to the full feathered bird is, as with the cuckoos, very rapid.

Nu KiB5 Six Birds, 16 Days Old

W. L. Baily

Notice the developing crest and absence of pin feathers. For many weeks after they are able to fly, the young birds are dependent upon their parents.

Nu KiB6 Immature on Stump. Decorah, Iowa

Hegner

This is a typical perch. Kingfishers though brightly colored resemble their parents in their first plumage.

Nu KiB7 Adult Female Perched on Twig with Sucker in Bill. Ithaca. (June 21, 1913) Allen

The food of this bird is chiefly fish and crayfish, which it catches by diving from some favorite perch near the surface of 
the water, as here, or hovering over the water until the right moment for diving comes. In some places, especially near fish hatcheries, kingfishers do considerable damage by feeding on the fingerlings. Observe the shape of the bill and the weak feet with the outer toes grown together.

\section{Lark, Prairie Horned (Otocoris alpestris praticola)}

This bird destroys a great number of weed seeds and deserves the fullest protection. Unfortunately early plowing destroys a great many nests with the young.

Call no.

Nu LdP Female at Ncst on Ground Fecding Four Young Birds. (April 1900)

Van Zant

This species nests late in March or early in April on the ground. The cold weather of early April does not seem to affect the eggs.

Nu LdP1 Male before Nest with Young. Decorah, Iowa. (April 23, 1901)

Hegner

Note the "horns," the conspicuous face markings and the rounded bill.

Nu LdP2 Nest with Three Eggs on Ground

C. Will Becbe

A depression lined with grasses.

Nu LdP3 Nest with Four Eggs in Snow. (April 1907)

Allen

Snow fell after these eggs were laid. Cold does not seem to affect the eggs as the female continues to incubate even though covered with snow. Here she has been flushed from the nest, which is seen to be dry, though the snow is several inches deep all around.

Nu LdP4 Nest with Two Young Birds in Snow

Bailey

The spotted back of the young makes it very inconspicuous when it crouches on the ground, but here the birds are revealed by the snow.

Nu LdP8 Female Bird on Camera, Side View. Geneseo. (1912)

- This camera was used to photograph the bird feeding her young. After feeding she repeatedly alighted on the camera. 


\section{Lark, Prairie Horned (continued)}

Another camera was brought and she was photographed in this position.

Call no.

Nu LdP9 A Flock Feeding. Chandlers Flats, near Gencseo Bailey

These birds are feeding on millet heads and scattered bird seed. The horned lark occasionally stays in New York all winter and is always among the first of the birds to come back in the spring, in February, while the snow still covers the ground.

\section{Longspur, Lapland (Calcarius lapponicus lapponicus)}

Slightly smaller than the snowflake and much darker. It resembles somewhat the common house sparrow. Regarded as uncommon in New York. It is a winter bird, lives entirely upon the ground, and walks instead of hops. It usually associates with horned larks or snow buntings. $\quad$ * 6.1-6.9; $q 5.5-6$

Nu Ln7 Four Birds at Feeding Station. Ithaca. (March 11, 1916)

\section{Loon, Common (Gavia immer)}

This bird is nearly three feet long and resembles the grebe. It is an expert diver and pursues fish beneath the water to great depths. In its mad pursuit of its prey in the Great Lakes, it is frequently caught in the nets of fishermen. On the wing it resembles a wild goose, but when migrating the flocks are always scattered and never in the $\mathrm{V}$-shaped formation.

$\mathrm{Nu}$ LoC2 Nest with Two Eggs. Higley lake, Ontario

Dutcher

The nest is usually in a hollow in the sand on an island, on a muskrat house or on a floating mass of debris. The eggs are about the darkest of any laid by our native birds.

$\mathrm{Nu}$ LoC4 Single Young Bird in Nest. Cove island, Ontario. (1912) Bailey

The young are covered with black down and are able to swim and dive shortly after hatching. 


\section{Mallard (Anas platyrhynchos)}

In the western part of the State this duck is mure common than in the eastern. It occurs chiefly as a transient, though it breeds to some extent within the State, particularly around the central lakes and Lake Ontario. The mallard is partly domesticated, and the domestic duck, which is derived from it, resembles it closely.

20-25

Call no.

Nu Mc1 Six Adults, Male and Female, Domesticated, ncar Water

The heavy bodies, large heads, thick necks and short bills show that these are domesticated birds.

Nu Mc12 Wild Bird (captive) in Eclipse Plumage. Ithaca. (September 22, 1918)

Allen

This plumage is worn from July until the middle of October. It corresponds to the winter plumage of most birds. The change from one plumage to another is gradual.

Nu Mc14 Wild Bird (captive), Male in Full Plumage. Ithaca. (October 27, 1918)

Allen

This plumage is worn from October until the last of July. The only change from this plumage takes place by feather wear. The gray edgings to the breast wear off, making it appear redder and the white band wider.

Compare the wild mallard with picture of domestic mallards, noting differences in shape of head, body and bill.

Nu Mc2 Nest with Nine Eggs, Photographed by P. B. Peabody, Hallock, Minn. and Nest with Ten Eggs, Photographed by Verdi Burtch, Branchport. (May 28, 1916)

The nest is usually on the ground near some marshy stream, but occasionally on a rotten stump. Note the thick, soft lining of the nest. The female plucks the down from her own breast to cover the eggs as incubation progresses. In the first picture the bird has scarcely begun to incubate.

Nu Mc3 Female (captive) on Nest. Ithaca. (June 9, 1917) Allen

Nu Mc8 Male and Female Jumping up for Flight. Ithaca. (March 18,1918 )

Allen 
Call no.

\section{Mallard (continued)}

Nu Mc82 Banded Male and Female Rising and Swinging. Ithaca. (March 18, 1918)

Allen

Note position of feet, wings and tail.

Nu Mc84 Banded Female in Full Flight. Ithaca. (March 18, 1918) Allen

Compare position of wings, feet and tail with $\mathrm{Nu} \mathrm{Mc} 8$ and $\mathrm{Nu} \mathrm{Mc82.}$

Martin, Purple (Progne subis subis)

This bird is the largest of the swallows and lives in cities and towns and near houses in the country. Perhaps no other bird has such beautiful gabled buildings arranged for it. In the South it nests in gourds put up for the purpose. It is a beneficial bird, feeding upon insects.

$7.5-8.5$

Nu MeP Two Adult Females on a Wire. Syracuse. (1909) Bailey

The females have gray breasts; the males are entirely steel blue.

Nu MeP8 Five Birds at Play about a Wire. Syracuse. (1910) Bailey

This species has a wing spread of 15 to 16 inches. The birds here shown are sunning themselves and pursuing passing insects. Note how the tail is spread.

Nu MeP9 Martin House and Martins. Syracuse. (1909) Bailey

Martins like to nest in colonies. A martin house, therefore, should have many compartments 6 or 7 inches in each dimension, entrance hole about $2 \mathrm{I} / 2$ inches across. It should be erected on a support from 15 to 20 feet tall. Even when thus provided for the martin is likely to be driven out by the house sparrow. It should be protected as much as possible. Note the sparrow on the wire to the right of the martins.

\section{Meadowlark (Sturnella magna magna)}

This familiar bird of the meadows arrives in March and remains till late in the fall. It belongs to the blackbird family. In many portions of the State it remains through the winter. 


\section{Meadowlark (continued)}

It is wholly beneficial and destroys a great number of noxious insects. It deserves protection throughout the whole country. o $10.5-11$; ㅇ 9 $9-10.5$

Call no.

Nu Mf Adult on Log in Grass with Food in Beak, Back View. Geneseo. (1912) Bailey

This bird spends much time on the ground. Note the white outer tail feathers, called "flash colors."

Nu Mf2 Nest with Four Eggs Partially Concealed in the Grass. Arcade. (May 19, 1904)

R. H. Beebe

The nest is usually placed at the end of a burrow in the grass and is arched over so as to be concealed from above.

Nu Mf1 Adult at Nest with White Grubs and Black Crickets for Young

Allen

The roof which covers the nest while the bird is incubating wears out as the adult goes in and out to feed the young.

Nu Mf5 Young Bird Hiding in Grass. Geneseo. (1911) Bailey

Young birds develop the fear instinct as soon as they are large enough to hide or to defend themselves.

Nu Mf6 Adult Cleaning the Nest. (June 9; 1915)

Allen

After each feeding the nest of this bird was cleaned and the excrement carried away to prevent fouling the nest. Note how the base of the bill extends back onto the forehead.

Nu Mf8 Adult on Log in Grass, Singing, Front View. Geneseo. (1912) Bailey

Note the bright yellow of the throat and belly and the black crescent on the breast. One does not often see these, for the bird commonly keeps his back to the observer.

\section{Merganser (Mergus americanus)}

Shelldrake is another common, name for this duck. It sometimes still breeds in New York, though its common breeding place is farther north.

o 24-27; $q 1$ to 4 inches shorter 
Call no.

\section{Merganser (continued)}

Nu Mh2 Nest with Eggs among Rocks. Georgian bay, Canada. (July 1912)

Bailey

Note how downy the nest is. The down is plucked by the female from her own breast. It is often built in an old stump or a hollow tree as well as in cliffs.

\section{Merganser, Red-breasted (Mergus serrator)}

20-25

Nu MhR8 Four Adults in Flight over Decoys in Water. Long Cove, Great South bay. (April 4, 1909)

Harper

The one in the lead is a female, the others males pursuing. The picture was made at the height of the courtship season. This species winters in large numbers on Great South bay. Note how narrow their bills are compared with those of other ducks.

\section{Nighthawk (Chordeiles virginianus virginianus)}

The name nighthawk is misleading, for the bird is not a hawk, but related to the whip-poor-will and swifts. It flies about at night, feeding upon moths, mosquitos and other insects that are in the air at that time. Its cry may be heard at night over cities and towns.

9.5-10

$\mathrm{Nu} \mathrm{Ni}$ Adult on Old Fence Post. Decorah, Iowa. (June 3, 1901)

Hegner

The nest is near by. The bird alighted on this post after being flushed. Note how horizontally it perches; also the short bill and large mouth. The weak feet are concealed.

Nu Ni2 Eggs on Graveled Roof. Kirk block, Syracuse. (1903)

Bailey

The nests are more commonly found in cities nowadays than in the gravel banks and quarries of the country. Every city that has flat graveled roofs gives this bird a nesting site. The eggs are usually two in number and so well marked that they are not easily seen in gravel beds.

$\mathrm{Nu}$ Ni4 Young Bird on Graveled Roof. Syracuse. (1903) Bailey

The young birds are covered with grayish down and are almost invisible on gravel or rough stones. 
Call no.

\section{Nighthawk (continued)}

Nu Ni6 Adult with Young on Nest on Ground. (1900)

Chapman

This is a good example of protective coloration.

Nu Ni7 Adult Asleep on Log. Weymouth, Nova Scotia

C. Will Beebe

During the day the nighthawk in wooded regions perches upon a log or limb; in the open country it roosts upon the ground. It can not perch upon small branches because its feet are too small and weak. It rests lengthwise on larger branches for better support and in so doing simulates a knot or bump.

\section{Nuthatch, White-breasted (Sitta carolinensis carolinensis)}

Among the most conspicuous of winter birds is this very interesting one that may be recognized by its peculiar habit of going down a tree head foremost. It has a harsh call, hardly in keeping with its colors. Its food consists of insects that it discovers in the crevices of bark and various other places. It is also fond of oily seeds such as those of the sunflower.

5.5-6

Nu NuW Adult on Side of Stump, Characteristic Position. (April 14, 1915)

Allen

This bird was attracted by suet forced into a hole in the stump. Note the long upcurved bill, short tail and perching-bird type of foot.

Nu NuW2 Adult Female with Food at Nest in Tree Trunk. Ithaca. (June 2, 1915)

Allen

Gathers its food chiefly from tree trunks and so does not have far to go from the nest to find it. Usually selects for its nest a cavity in a tree entered through a lnot hole.

Nu NuW3 Adult on Small Limb, Seen from Below. Arcade. (1905) R. H. Beebe

Nu NuW4 Adult Feeding on Suet Placed on a Limb, Side View. Geneseo. (1910) Bailey

Nu NuW6 Four Young Birds with Heads Pointing Upward toward Mother Bird, Two Young Birds on Stump Below. Geneseo. (1909)

Bailey

The young resemble their parents. 
Call no.

\section{Nuthatch, White-breasted (continued)}

Nu NuW7 Seven Young Birds in a Row, Adult Bird Clinging to Perch from Below. Geneseo. (1910) Bailey

Nuthatches climb about in any sort of position.

Nu NuW8 Eleven Young Birds of One Brood Posed in a Row. Geneseo. (1911) 1 Bailey

The family was raised in a box put up originally for gray squirrels. So large a brood is exceptional.

Nu NuW9 Adult with Wings and Tail Spread Driving House Sparrow from Feeding Station. Ithaca. (February 1914)

Allen

The wings and tail are spread and the feathers shaken out, displaying the black and white marks that are ordinarily concealed, in an effort to appear as large as possible. This suggests another use for "flash colors" than that of protective coloration. This display is doubtless also used during the courting period. As the bird advances, it sways from side to side and points its long bill in a threatening manner.

For junco driving nuthatch from feeding station, see Nu JuS8.

\section{Oriole, Baltimore (Icterus galbula)}

Another bird that seems to prefer the company of man, for it nests from choice about the buildings in the country and in the trees of our village streets. Now and then the oriole helps itself to cherries, but the good it does during the other months more than repays for what few cherries it takes. $\delta 7-8.2 ; q 7-7.6$

Nu OrB Male and Female on Branch above Nest. (June 12, 1914)

A very representative picture as to the nest, the tree and the birds. Give it special study, noting species of tree, the material used for the nest, its form, structure, position etc., the shape and coloration of the birds. Some of the leaves have been removed that would otherwise entirely conceal the nest except from below.

Nu OrB2 Gathering Strings for a Nest. Ithaca. (May 19, 1916)

Allen

Strings and yarn should be put out about the first of May to encourage orioles to nest in your vicinity. 
Call no.

\section{Oriole, Baltimore (continued)}

Nu OrB3 Building Nest in Cut-leaf Maple near Nest of Previous Year. Ithaca. (June 1, 1917)

Allen

The old nest is in the lower left-hand corner. What guides the bird on its way from Central America to its former nesting site?

Nu OrB4 Young Birds Perched above Their Nest

Oftentimes, when bits of variously colored strings are put out, the oriole will select the light-colored ones.

\section{Osprey (Pandion haliaëtus carolinensis)}

Abundant about the seashore, but uncommon in the interior of the State. It pounces upon fish in the water and carries them away to its nest or to some favorite site, feeding upon them. In some bodies of water the bald eagle pursues it, makes it drop the fish and not infrequently catches the fish before it strikes the water. This is the common fish hawk.

20-24

\section{$\mathrm{Nu}$ Os Adult at Nest with Eggs}

The place of the nest varies greatly. Where they are given complete protection, as on Gardiners island, they nest on the ground or anywhere; in other places they select high trees. What do the several nesting sites shown in this series of pictures have in common?

\section{Nu Os2 Nest with Three Eggs}

Nu Os4 Two Adults Flying to Nest in Tall Tree

Chapnan

This is the usual sort of nesting place where the birds have enemies.

Nu Os5 Nest on Top of a Telegraph Pole

Hatharway

An unusual nesting site.

$\mathrm{Nu}$ Os6 Nest on Stumps of Uprooted Trees. Gardiners island

Chapman

Nu Os7 Adult on Nest on Roof of Shed, Doctor Chapman Pulling String to Release the Shutter of Camera. Gardiners island. (June 1901) 
Call no.

\section{Osprey (continued)}

Nu Os8 Adult over Nest. Gardiners island

Chapman

$\mathrm{Nu}$ Os9 Adult with Wings and Tail Spread About to Aliglit on Nest. Gardiners island. (June 9, 1911)

IIarper

Observe specially how the wings are used in directing the bird's course and in retarding its movement. The feet are dropped ready to land.

\section{Ovenbird (Seiurus aurocapillus)}

The ovenbird is known also as the teacher bird and as the golden-crowned thrush. It belongs with the group of warblers. The name ovenbird is given to it because it builds a roofed nest like an old-fashioned oven. The name teacher bird is derived from its call, while the term golden-crowned thrush is derived from the color of the crown. This bird is fairly abundant in the drier woods.

$\mathrm{Nu}$ Ov2 Adult at Nest. (June 8, 1900)

Chapman

The nest is rather bulky, is placed upon the ground often as here at the foot of a small sapling or under a recumbent dead twig, and is built of brown leaves and grass of the preceding year. The nest is not easily discovered. Where is the entrance?

Nu Ov3 Nest with Eggs in Brush Surrounded by Growth of Swamp Saxifrage, Skunk Cabbage, Jack-in-the-Pulpit and Other Plants. Potters swamp, Branchport. (June 6, 1909)

Burtch

While such swamps are not the usual nesting places of the ovenbird, a number of nests have been found in Potters swamp. Note how perfectly the nest is concealed. One might easily overlook it in passing.

\section{Owl, Barn (Aluco pratincola)}

The name monkey-faced owl is given this bird because of its odd visage. It is unusually helpful and feeds almost exclusively on squirrels, reptiles, mice and insects. It frequents barns. Its habits are nocturnal. It is considered somewhat rare in New York as it is more a southern bird, though it is found in many parts of the State. 
Call no.

\section{Owl, Barn (continued)}

Nu OwB Adult in Crotch of Old Tree. (1902)

Nu OwB2 Nesting Site in a Hollow High in Tree. (1902)

It nests also in secluded towers, belfries and barn attics.

Nu OwB3 Nest with Two Eggs in Old Tree Stump. (1902)

It lays from five to eleven eggs and rears two broods a season. All owls lay pure white eggs.

Nu OwB4 Two Birds Sixtcen Days Old. (1902)

Note the forming facial disk; the bill not yet very strongly hooked, the position of toes, the outer toe reversible.

Nu OwB5 Two Birds Twenty-eight Days Old. (1902)

They have now acquired their adult feathers.

Nu OwB6 Single Bird 110 Days Old on Post. (September 1913)

\section{Owl, Barred (Strix varia varia)}

One of the least harmful of the large owls. It differs from the great horned owl in the absence of ear tufts. It is noisy at night and its hooting ends with a mournful wail. It frequents the denser timber land. It is the commonest owl in the Adirondacks.

$19.5-24$

Nu OwC Adult (captive). (1900)

Barring across breast serves to identify this species. It has ruffled its feathers and assumed a defensive attitude.

Nu OwC2 Two Eggs in Hollow of Stump. (1904)

The nest is usually in the hollow of a tree or in an old nest of a crow or a hawk. No nest is built.

Nu OwC4 Two Young Birds Perched on Fence. (1904)

Note position of the toes. 


\section{Owl, Great Horned (Bubo virginianus virginianus)}

A permanent resident throughout New York, though no longer common except in wooded districts. It is nocturnal in its habits. The best authorities grant that this bird feeds upon domestic fowls from time to time. However, the great amount of its food is weasels, rats, mice, rabbits and skunks. Fowls that are properly cared for are not usually destroyed by this night prowler. It is usually the careless farmer who allows his poultry to find roosting places anywhere that suffers from this bird.

\section{Call no.}

21-24

Nu OwG Adult. (1905)

It is probable that this bird was a captive when photographed.

Nu OwG1 Adult Threatening. (1905)

As the bird was approached by the photographer, it showed a fighting disposition.

Nu OwG2 Nest with Two Eggs in Hollow of Tree. (March 1910)

The eggs are laid as early as February usually in hollow trees or deserted crow's nests. The growing scarcity of hollow trees is one cause for the diminution of this bird.

Nu OwG3 Nest with Two Eggs and One Young Bird in Crotch of White Pine Tree, Rat and Bird for Food on Edge of Nest. Cascadilla valley, Ithaca. (April 1, 1908) Allen

This nest is 60 feet from the ground. Note that it is not in the hollow of a tree. Note also the character of the food at the nest. Find out how much such food a single bird catches in a year. This bird is sometimes at least beneficial. When was the picture made?

$\mathrm{Nu}$ OwG4 Nesting Site in Cliff of Shale Rock. (1904)

An unusual nesting site.

Nu OwG5 Young Bird Posed on Top of Post. Geneseo. (April 27, 1908)

Bailey

The bird is just able to fly from one tree to another, but is not able to take its own food. No tufts have yet appeared. 
Call no.

\section{Owl, Great Horned (continued)}

$\mathrm{Nu}$ OwG6 Young Bird on Perch (flashlight), Side Vicw. (April 27, 1908)

Bailey

Note how it simulates the broken stub upon which it is perched.

Nu OwG7 Adult in Flight Leaving Nest in Carity in High Tree. Geneseo. (1912)

Bailey

Nu OwG9 Food Taken from Nest. Genesco. (1912)

Bailey

This food, taken at one time, consisted of a weasel, a pheasant's $\mathrm{lcg}$ and the legs of a rabbit. The picture shows that the bird is beneficial as well as destructive.

\section{Owl, Long-eared (Asio wilsonianus)}

This bird is intermediate in size between the screech owl and the great horned owl. Ear tufts are conspicuous. It is less common than either in most parts of the State, living in dense patches of evergreens. It is useful, killing many mice and nightflying insects.

$13-16$

Nu OwL Adult Brooding on Nest in Small Pine Tree. Geneseo. (May 13, 1914)

Bailey

Note how the old bird throws out her feathers in order better to cover her brood and intimidate the photographer.

Nu OwL2 Nest with Five Eggs in Small Pine Trec. Genesco. (April 18, 1914)

Bail'y

Note specially how the nest is built and what material is used; built by a pair of crows the preceding year, the owl adding nothing to it.

Nu OwL3 Young Birds in Nest in Small Pine Trec. Gencsco. (May 13, 1914)

Bailey

Nu OwL4 Young Bird in Normal Pose. Geneseo. (May 28, 1914)

Bailey

Nu OwL5 Two Young Birds Perched on an Old Log, Threatening. Geneseo. (May 28, 1914)

Bailey

Compare with the preceding picture. 


\section{Owl, Saw-whet (Cryptoglaux acadica acadica)}

The smallest of the New York owls. Distinguished by absence of ear tufts. It prefers swampy woods and keeps hidden during the day in dense foliage or in a hole in a tree.

$7.25-8.5$ Call no.

\section{Nu OwR4 Three Young Birds in Different Positions}

The young birds are more uniformly colored than the adults.

\section{Owl, Screech (Otus asio asio)}

The most abundant and most widely distributed of the owls. It has two color phases independent of age, sex or season, some individuals having the predominating color grey and others reddish. Intermediates likewise occur. The food of this owl is almost exclusively insects and rodents. Occasionally it feeds upon small birds, particularly English sparrows, hunting them out by night in cornices of buildings, trees and between loose bricks of buildings.

$7.5-10$

Nu OwS Adult in Its Retreat in Old Stump. Genesco. (1910)

Observe protective coloration.

Nu OwS1 Adult Looking from Hole in Tree

Nu OwS2 Immature Bird with Wings Spread (automatic flashlight). Geneseo. (July 26, 1917)

Bailey

Nu OwS24 Six Young Birds of Different Sizes but from One Brood Posed on Limb. Ithaca. (May 21, 1916) Allch

Nu OwS3 Two Birds 24 Days Old Posed on Small Twig

Bailcy

Note the developing tufts and position of toes.

Nu OwS4 Two Posed Birds 24 Days Old, Alarmcd. (Junc 5, 1906)

Note that the feathers are finely crossbarred.

Nu OwS5 Two Large Young Birds on Limb of Pine Tree. (1901)

Notice the half-opened eyes. The bird assumes this expression in the presence of sunlight because of the large size of the pupils. Enough light, however, is admitted so that it can see perfectly in daylight. 
Call no.

\section{Owl, Screech (continued)}

Nu OwS6 Adult on Perch, Posed

Bailey

Nu Ows7 Adult in Red Phase in Oak Tree. Ithaca. (November 27, 1916)

Allen

Nu Ow9 Bones of Rodent and Pellets from Owls. Genesco. (1911)

Bailey

The large pellet is that of the great horned owl. Below it are two smaller pellets of the screech owl. These pellets are regurgitated from time to time and contain most of the coarse indigestible material of the food of these birds. By examining these pellets it is a simple matter to determine the feeding habits of the various species of owls.

\section{Owl, Short-eared (Asio flammeus)}

Associated especially with lowlands and marshy districts but quite widely distributed throughout the State. Field mice constitute about 80 per cent of its food and this owl becomes unusually abundant when there is an invasion of mice. A permanent resident.

$13.7-16.5$

Nu OwT Adult on Ground (wounded). Ithaca. (Junc 24, 1917)

\section{Partridge, Hungarian (Perdix perdix)}

Allen

The common European partridge was liberated in several localities in New York State during the spring 1909 under the name of Hungarian partridge and soon became acclimated.

Nu PcH Adult Hiding in a Rail Fence, Side View. (May 16, 1914)

Bailcy

This bird was injured by striking a barbed wire fence.

\section{Pelican}

An unusual bird for New York, but it has been found here from time to time. It was more common here in colonial days. For a number of pictures of pelicans, see List 35, Florida.

Pewee, Wood (Myiochanes virens)

A most valuable bird because of the great number of flying insects it destroys. It is a summer resident throughout New 


\section{Pewee, Wood (continued)}

York. It nests close to houses in the trees of the yards, as well as in the woods.

$6-6.5$

Call no.

Nu Pi Adult on Drinking Log, Side Vicw. (Octobcr 1914) Bailey

The bird came to the drinking log after insects that were crawling about. The day was cold and few insects were flying.

\section{Nu Pi2 Nest with Two Eggs in Apple Tree}

The nest is usually placed on a horizontal limb. It is made of plant fibers and frequently covered with mosses and lichens, which give it the appearance of the lichen-covered branch on which it is placed, hence the nest is easily overlooked. The center of the nest is sometimes very thin so that the eggs nearly rest on the branch. Compare nest with that of the hummingbird.

Nu Pi3 Adult Incubating. Genesco, (1911)

Bailey

Note position of nest, which is in an elm tree about 35 feet from the ground.

Nu Pi4 Adult on Limb before Young Bird in the Nest. Becbe lake. (July 15, 1915)

Allen

The nest resembles a knot of the dead limb on which it rests. The young bird has just been fed. Note the upright posture of the old bird, which is characteristic of all flycatchers. The pewee is similar to the phoebe, but the wing bars are more conspicuous. It is a grayer bird and its notes are very different. Note the flycatcher bill and bristles and the perching bird type of foot.

Nu Pi7 Adult on a Typical Perch and in Flycatcher Pose. Ithaca. (July 1917)

Allen

From such a position the pewee watches and flies out for food on the wing.

\section{Pheasant, Ring-necked (Phasianus torquatus)}

The ring-necked pheasant is an introduced species. It has been interbred in many cases with the English pheasant so that there is some variation in color. In many parts of the east, 


\section{Pheasant, Ring-necked (continued)}

particularly in central New York, it outnumbers the native game birds. Fortunately, it is for the most part beneficial, and the majority of farmers over whose acres it roams are staunch friends of this hardy bird. During severe weather in the winter it is not unusual for it to come to the barnyard and feed with the domestic animals. Many times cracked corn, buckwheat and other grain are placed out in its cover especially for it.

Call no.

Nu, PjR Adult Male and Female on Ground where Grain Has Becn Placed. Geneseo. (April 17, 1915)

Bailey

The female resembles somewhat the grouse but has a long pointed tail. Note the short hind toe characteristic of all fowllike birds. The white ring around the neck of the male is called a "ruptive mark" and seems to cut off the head.

Nu PjR2 Nest with Eight Eggs in Mcadow. Gencseo

Bailey

The nest is a mere depression with scarcely any lining.

Nu PjR3 Adult Female Incubating. Genesco. (May 29, 1914)

Bailey

Nu PjR4 Nest with Young Birds and Broken Egg Shells. Geneseo. (May 27, 1914)

Bailey

These birds were photographed during a rain storm early in the morning, just before they left the nest to roam with the mother. Note how evenly the egg shells were broken by the hatching young.

Nu PjR6 Mrs Allen beside Female on Nest. (May 15, 1915) Allen

The picture illustrates the fact that the bird defends its nest and is not readily driven away. Most pheasants, however, are rather timid about the nest.

Nu PjR7 Adult Male Walking with Head Erect. (March 26, 1915)

Nu PjR8 Two Tracks in the Snow. Ithaca. (January 1918) Allen

Note the cleanness of the track, showing wide angle of front toes and small hind toe. Compare with track of crow. 


\section{Phoebe (Sayornis phobe)}

The first of the flycatchers to arrive from the South, reaching central New York early in April. At this time it feeds upon flies that are emerging from their winter quarters and other insects that start the insect life in the spring.

Call no.

Nu Pk Adult on Twig near Nest, Front Vicw. Genesco. (1911)

Nu Pk1 Adult on Perch, Side Vicw. (August 15, 1915) Bailey Bailey

This bird is watching for insects. The click of the shutter has caused it to crouch. It ordinarily sits more erect.

Nu Pk2 Nest with Four Eggs in Shale Rock on Shelving Bank

Of what is the nest constructed?

Bailey

Nu Pk3 Nest and Eggs on Ledge of Rocks

Formerly this bird nested wholly on rock ledges. But nowadays it more commonly nests in buildings and on the timbers of bridges. Nests in the rock are more often found by the cowbird than are those in buildings. This may account for the preference of the phoebe for buildings. It also prefers the vicinity of water.

Nu Pk32 Old and New Nests Side by Side on a Ledge of Rocks. Ithaca. (May 17, 1908) Allcn

The phocbe returns to the same spot year after year. Which of these nests was built the later?

Nu Pk4 Nest Filled with Young Birds, in Old Building

Note the broad flat bills of the flycatcher family.

Nu Pk5 Three Young Birds on Small Limb. Lake George. (July $10,1907)$

Bailey

The adult has just.flown near the young, the blur of the wing showing on the extreme left in the picture. This accounts for the open mouth of the young on the right.

Nu Pk35 Two Young Birds in Nest under Ledge of Moss-covercd Rock. The Big gully, Guyunoga. (June 15, 1913)

Burtch

Gullies are a favorite home for the phoebe, especially under orcrhanging roots or rocks. From the date of this picture this 
brood seems to be the second of the season. The phoebe seldom uses the same nest twice because before the second birds are old enough to fly the nest becomes infested with small black lice.

\section{Pigeon, Passenger (Ectopistes migratorius)}

This beautiful bird is now almost certainly extinct. It is believed that the last bird died in the Cincinnati Zoological Park, September 1, 1914. The latest record of it in New York is for 1898. In 1868 there was a great nesting of these pigeons in Allegany county. A single tree in some cases had 30 to 40 nests. The nesting tract was 14 miles long. Birds were killed and shipped to New York City by the carload. There was a very large roost in Steuben county in 1875, but probably no breeding. Immense flocks were common in colonial days and great roosts continued to be common through the first half of the nineteenth century.

$15-17.25$

Call no.

Nu PmP8 Adult with Other Pigeons in Nesting House. From negative owned by R. W. Hegner

Widman

The passenger pigeon is the one with a long tail on the highest roost. Compare with the common pigeons.

Nu PmP Adult (muscun specimen). Photographed in the American Muscum of Natural History

\section{Pintail (Dafila acuta)}

A fairly common migrant in the coastal region and more common in the marshcs of western New York. At dusk it comes into shallow water to feed. It appears in small flocks during the spring and fall migration.

ơ $26-30$; ᄋ $20-24$

Nu Pn Male on Plank (captive). Ithaca. (June 25, 1918) Allen

Note the size of the feet and the position of the legs of the pintail and the teal and compare with those of the canvasback, which is a diving duck.

Nu Pn1 Female on Plank (captive). Ithaca. (June 25, 1918) Allen

Nu Pn8 Two Banded Females in Flight, Released for Study of Migration. Ithaca. (March 18, 1918)

Allen 


\section{Call no. \\ Pintail (contimued)}

Nu Pn2 Male in Eclipse Plumage. Ithaca. (Scptember 22, 1918)

Allen

This eclipse plumage corresponds to the winter plumage of other birds but is worn only from August to November or December.

\section{Plover, Black-bellied (Squatarola squatarola)}

This is a hol-arctic species that commonly migrates through New York, especially by way of Long Island. The bird is shy and difficult to bring within near view.

10.5-12.25

Nu PpB Adult Wading near Muskrat House. The marsh at Branchport. (October 3, 1911)

Burtch

The plumage of this bird is quite different in spring from that shown in this picture. The throat, foreneck, breast and belly are then black.

Plover, Golden (Charadrius dominicus dominicus)

See map of spring and fall migration routes, with inset of female, Nu ZM5, p. 166.

\section{Plover, Semipalmated (Egialitis semipalmata)}

Known also as American ring-neck. The species frequents sandy beaches, mud-flats and marshes. In New York it is a migrant, more common along the coast than on inland waters. It is suggestive of the killdeer in appearance, though it is smaller and has a shorter bill and tail.

6.5-7.8

Nu PpS Adult on Mud Flat. Conesus lakc. (September 7, 1917)

\section{Plover, Upland (Bartramia longicauda)}

Bailey

This bird, also known as the Bartramian sandpiper, is perhaps the next game bird that is doomed to extinction. In many parts of the State where it formerly occurred in abundance it is now practically unknown. Western New York appears to be the last stamping ground of this once abundant bird. It migrates before the hunting season opens so that few of them are killed in this State, but on its southern trip it was formerly shot ruthlessly. It is now protected by the federal migratory bird law. 
Call no.

\section{Plover, Upland (continued)}

Nu PpU8 Adult Alighting in Tree-top. Gencseo. (June 1913)

A tide-water bird but a regular fall migrant in central New York. This picture and $\mathrm{Nu} \mathrm{PpU} 4$ indicate that the bird sometimes nests in central New York in June. It is the only sandpiper that regularly alights on trees or on telephone poles.

Nu PpU2 Nest with Four Eggs in Grass. Geneseo. (1912) Bailey

The grass has been parted to show the eggs. The eggs are very large for the size of the bird. The nest is of the simplest character. Why?

$\mathrm{Nu}$ PpU4 Four Young Birds in the Grass. Gencsco. (Junc 11, 1915)

Bailey

These birds leave the nest as soon as hatched and wander about, following the adults. They are very protectively colored.

\section{Rail, Clapper (Rallus crepitans crepitans)}

This rail belongs to the Atlantic seaboard. In the stmmer it is a common resident of the salt marshes of $\mathrm{New}$ York going up the Hudson as far as Ossining. This bird is known also as the mud hen, a term often applied to the gallinule and the coot.

$13.5-16$

Nu RD2 Nest on Ground with Three Young Birds and Six Un-. - hatched Eggs

The black downy covering is characteristic of all young rails.

\section{Rail, Virginia (Rallus virginianus)}

A bird of the swamps, more often heard than seen. In the states of Pennsylvania and New Jersey it is hunted systematically.

Nu RV Adult Moving over Broken-down Reeds, Approaching Nest. Renwick swamp, near Ithaca. (June 8, 1910) Allen

Note the length of its toes and judge how it is able to walk readily over muddy ground or floating vegetation. This game 


\section{Rail, Virginia (continued)}

bird escapes its enemies quite readily by running through the reeds and rushes. Note the compressed form of the body for slipping between the reeds. How does it compare with the herons?

Call no.

Nu RV1 Nest with Nime Eggs in Recds

Bailey

The Virginia rail builds its nest in rather wetter positions than does the Carolina.

Nu RV3 Adult Incubating, Side Vicw. Long Branch. (Junc 1911)

Note how high the nest is built. Why?

Nu RV4 Adult Incubating, Front View. The marsh at Branchport. (June 11, 1908)

Burtch

The young rails begin to run about almost as soon as they are hatched. When this nest was found, the mother bird left it and was followed by two or three of the young that were out of the shell. While focusing the camera on the nest, the bird came back carrying a young one in her beak, deposited it in the nest and settled down on it while several plates were exposed. Sne picked the fingers of the photographer and changed position when approached.

Nu RV5 Three Young Birds and Five Unhatclied Eggs in Nest. Long Branch. (June 1911) Bailey

The young birds are entirely black but change their color later. Note one of the eggs partially hatched and the egg tooth on the bill that projects.

Nu RV6 Adult Feeding in Marsh. Branchport. (July 23, 1911)

Burtch

Very characteristic. Rails feed on aquatic animals and on seeds and tender shoots of plants. Note that the bird does not sink far into the soft ooze.

Nu RV7 Adult Hunting for Food with Young Bird Following. The marsh at Branchport. (July 23, 1911)

Burtch

Only one young bird followed the adult at one time; the others kept back in the flags until she found some food. This species 


\section{Rail, Virginia (continued)}

is precocial, but the parent helps it to find and select food. Compare hen and chickens. The young bird is still in the down.

Call no.

Nu RV8 Female Carrying Young Bird in Its Bill. Branchport. (June 17, 1915)

Burtch

The young birds of the brood were removed from the nest to a shallow depression in the ground. The mother came here for them and carried them away into the grass.

Nu RV9 Adult with Wings Extended, Balancing Itself on Wire Fence. Renwick, near Ithaca. (June 19, 1910) Allen

The fence was placed about the nest to keep the young from scattering. It was, however, ineffective for the purpose, as the old birds soon learned to jump over it and carry the young away. The rail is a poor flyer. Note the short, round wings.

\section{Redstart (Setophaga ruticilla)}

A strikingly colored, fairly abundant warbler. Its food is varied, there being few kinds of tree insects that escape it. $\mathbf{5 . 4 2}$

Nu Rf1 Fenale Incubating. Ithaca

Hankinson

Smaller than the sparrow. This picture makes both the bird and the nest appear larger than they are. The bird nests in the smaller trees or undergrowth of woods.

Nu Rf2 Nest with Three Eggs. Onondaga Valley. (1903) Bailey

The nest of this bird is cup-shaped and very neatly constructed. This particular one is somewhat distorted in shape, the branch to which it is so firmly attached having been pulled down for photographing.

Nu Rf5 Female Fecding a Young Cowbird. Ithaca. (July 22, 1909) Bailey

The redstart shows as much concern when the young cowbird is disturbed as if it were her own.

For map showing distribution and migration of this bird, see Nu ZM6, p. 166. 


\section{Robin (Planesticus migratorius migratorius)}

Probably the most familiar New York bird. It is a thrush. It prefers to nest near the habitations of man, often on window ledges and veranda posts.

Call no.

Nu Ro Adult on Lawn

Dutcher

Nu Ro2 Nest: with Five Eggs in Crotch of Apple Trec. (1910)

Of what material is the nest of the robin built? It is bulky; not very well constructed or properly cared for after the eggs are hatched. The middle layer, made largely of mud, is shaped by the bird pressing her breast against it. A lining of dry grass is then added.

$\mathrm{Nu}$ Ro4 Four Young Birds in Nest. (1907)

Nu Ro5 Immature Bird on Perch. (July 26, 1914)

Bailey

Bird coming to a drinking place. Notice the spots on the breast, indicative of the thrush family.

Nu Ro6 Adult in the Snow during a Rain. Genesco. (1910) Bailey

The robin often needs to be helped to food when snow falls in the late spring. A few robins remain in the State throughout the year.

Nu Ro7 Adult Fenalc Covering Brood during a Rain, Nest in Open Chicken Yard. West Edmeston. (1907)

Note how the wings are extended to protect the young birds.

Nu Ro74 Adult Giving Cries of Distress near Nest. Ithaca. (June 8,1908 ) Allen

When their nests are disturbed, birds act differently, the robin usually perching near by and uttering loud cries of distress but sometimes darting at the intruder. Compare this picture with those of the black tern and the least bittern.

Nu Ro8 Adult Eating Crumbs from Feeding Station. Geneseo. (March 28, 1913)

Bailey

Notice the white tip to the outer tail feathers. This tip is conspicuous in flight. During the snows of April robins are sometimes without food. They will then eat crumbs and friedcakes. 
Call no.

\section{Robin (continued)}

Nu Ro84 Adult on Log, Side View. (May 14, 1914)

Allen

This pose is very characteristic.

Nu Ro9 Adult at Drinking Trough. (Junc 1914)

Water is quite as essential for robins as food. They need water in the hot days of July and August.

Nu Ro95 Normal and Albino Birds. Mounted specimens, New York State Museum. (1919)

For map showing winter and summer range of this bird, sce Nu ZM54, p. 166.

\section{Sanderling (Calidris leucophaa)}

Called also surf snipe. A widely ranging shore bird, the whitest of our sandpipers, common along the coast of New York and along the Great Lakes, especially during the fall migration.

$7-8.75$

Nu Sal Adult Standing on Sandy Beach. Cayuga lakc. (Scptcmber $10,1911)$

Allon

This bird is in fall plumage.

Nu Sa8 Adult Standing Asleep with Head under Its Wing. Sliore of Cayuga lake. (September 10, 1916)

Allen

Sandpiper, Least (Pisobia minutilla)

The smallest of the sandpipers, a common migrant along the coast and inland waters of New York.

$5-6.75$

Nu SL Adult at Water's Edge. Chautauqua. (August 1911) Allen

When resting, birds often draw up one leg bencath the breast feathers.

Nu SL8 Flock Flying over the Water. Chautauqua. (August 1911)

Allen

This picture shows the characteristic close flock and swallowlike appearance of the birds in flight. 


\section{Sandpiper, Pectoral (Pisobia maculata)}

Sometimes called "grass snipe." It is more frequently found on grassy shores even back from the water than are most sandpipers. It nests in the far north and is most common in New York from August to November on its fall migration.

8-9.5

Call no.

Nu SP Adult Walking on Shore. The marsh at Branchport. (October 8,1911 )

Burtch

Note the counter shading of this bird. The photograph makes it appear even more conspicuous than it does in nature. Its color pattern simulates the dead grass on the shore and further renders it inconspicuous.

\section{Sandpiper, Red-backed (Pelidna alpina sakhalina)}

This species breeds in the Arctic regions and winters from the Gulf to South America. In New York it is a common migrant. As a rule it occurs in flocks.

$8-9.25$

Nu SQ Threc Adults Wading ncar Shorc. Hollisters swamp, on Keuka lakc. (October 13, 1912)

Burlch

The back is redder during the breeding season and there is a black patch on the belly. The slightly curved bill is a good field mark. These birds are beautifully counter shaded and when seen on a gray shore are almost invisible; against the water they are conspicuous. Compare with counter shaded models, Nu ZC2, p. 150.

Sandpiper, Semipalmated (Ereunetes pusillus)

Known also as peeps; a very small shore bird. It breeds in the Arctic regions and winters about the Gulf of Mexico.

$5.5-6.55$

Nu SR Adult Wading along the Shorc. Ithaca. (August 1910) Allen

It is very similar to the least sandpiper but grayer.

Nu SR8 Large Flock in Flight over Mud-flats. Near Amityville. (July 28, 1912)

Harper

After feeding for several hours in the early morning, these sandpipers congregate in large numbers on the mud-flats to rest 
and doze. They are here seen taking wing at the photographer's approach. It is probable that some least sandpipers are mixed with the flock.

Sandpiper, Solitary (Helodromas solitarius solitarius)

As the name would imply, this sandpiper is not gregarious. Next to the spotted it is the commonest and most widely distributed sandpiper in New York State, frequenting on its migrations any stream, pond or mud flat even in the woods where other sandpipers do not venture.

$7.5-9$

Call no.

Nu SS Adult in Marshy Stream Secking Food. Branchport. (July $28,1911)$

Burtch

The solitary sandpiper is found around Branchport and Potters swamp as late as May 30th, when it leaves for its breeding grounds. It returns as early as July 6th. Its barred white outer tail feathers distinguish it from the spotted sandpiper in any plumage.

\section{Sandpiper, Spotted (Actitis macularia)}

No bird is more characteristic of our rivers and streams than this familiar sandpiper, or "tip-up." Its cry of alarm as it rises from a shoal is well known to the fisherman and the small boy of the country. Unfortunately it is sometimes shot in the fall along with the other shore birds. It is decidedly beneficial and is protected by the laws of New York and the federal migratory bird law.

$7-8$

Nu ST2 Adult Approaching Nest with Eggs on Ground under Mullein Plant. Arcade. (1914)

R. H. Beebe

Note coloration, also position and character of the nest; the long legs, relatively short toes and slender bill of the bird; the size of the eggs compared with the size of the bird. Compare with rose-breasted grosbeak, Nu GtR3. The sandpiper is smaller. than the grosbeak, but its eggs are larger.

Nu ST24 Nest with Four Eggs on Ground. Palisades park. (July 20, 1918)

For a further study of the comparative size of eggs of precocial and altricial birds, see catbird and spotted sandpiper with an egg of each, $\mathrm{Nu} \mathrm{Cd} 3$, p. 130. 
Call no.

\section{Sandpiper, Spotted (continued)}

Nu ST3 Adult Incubating. Renwick, near Ithaca. (Junc 21, 1911)

Allen

The bird is small compared with the size of the eggs, but she manages to cover them.

Nu ST6 Adult on Hump of Mud in Flooded Area. Ithaca. (August 1912)

Allen

At this time the bird was in its fall plumage. Note the absence of spots.

Sapsucker, Yellow-bellied (Sphyrapicus varius varius)

The name sapsucker is given this bird because it drills several holes in various kinds of trees and later, when the sap has begun to flow, makes the rounds again, drinking the sap from them. The damage done is ordinarily not great, because the bird is not abundant.

$8-8.8$

Nu ScY Adult Male on Trunk of Tree, Side View. (1906) Bailey

Note the white shoulder stripe. The red throat proves it a male.

Nu ScY6 Two Pictures of Same Adult on Tree Trunk: at Work. (left); Resting (right). Ithaca. (April 19, 1915) Allen

Note the arrangement of holes in a row and the bark wet by the flowing sap.

$\mathrm{Nu} \mathrm{ScY} 7$ Adult with Bill Inserted in Tree, Drinking.

Bailey

Note how the bill is placed in the hole and the drinking is done. This bird does not drill for insects at this season as do other woodpeckers.

Nu ScY8 Adult with Food at Entrance to Nest in Tree Trunk. Cranberry lake. (June 30, 1916) Bailey

Note that the young are fed upon insects. 


\section{Shrike, Migrant (Lanius ludovicianus migrans)}

Formerly known as the loggerhead. With beak for tearing and the weak claws of a song-bird, the shrike presents an interesting study. This bird feeds upon grasshoppers and mice and other small animals and occasionally upon the smaller song birds. It seeks an exposed perch with open view where it can watch for its food.

Call no.

Nu SiM Pair of Adults on Edge of Nest. (May 24, 1910) Bailey

The pair now and then come to the nest together with food. In what kind of a bush is the nest placed?

Nu SiM1 Nest with Two Eggs in Grapevine. Onondaga Valley. (May 1903)

Bailey

The nest is usually placed low. Note with what material it is lined. Compare this with that of the exterior.

Nu SiM2 Nest with Five Eggs in Thorn Apple Bush. Arcade, (April 1, 1905)

R. H. Beebe

Only three of the eggs can be seen in the picture. Study the composition and structure of the nest.

Nu SiM3 Adult on Nest in Thorn Apple Bush, Showing Back. Arcade. (May 8, 1905)

R. H. Beebe

Nu SiM4 Adult Incubating, Showing Head and Breast, Nest in Thorn Apple Bush. Genesco. (May 24, 1910) Bailey

$\mathrm{Nu}$ SiM5 Two Young Birds in Nest. Geneseo. (May 24, 1910) Bailcy

Nu SiM6 Two Young Birds Standing on Edge of Nest

Nu SiM7 - Four Young Birds Just after Leaving the Nest, Perched in a Thorn Apple Bush. Geneseo. (1911) Bailey

Nu SiM8 Adult and Five Young Birds on Stump. Arcade. (1905)

Do the young resemble the adults?

R. H. Beebe

Shrike, Northern (Lanius borealis)

$10.1-10.5$

$\mathrm{Nu}$ SiN Adult on Post. Ithaca. (February 1918)

Allen

The bird during a heavy fall of snow has been attracted by a piece of meat from a duck. Note the shape of the bill. 
Call no.

\section{Shrike, Northern (continued)}

Nu SiN8 Adult Attracted by Decr Mouse Fastened in Thorn Bush. Ithaca. (February 1918)

Allen

Mice form an important part of the food of this species. Note that the mouse is fastened onto a bush much as if the bird itself had placed it there.

Nu SiN9 Vesper Sparrow Impaled on Thorn by Northern Shrike

Bailcy

The shrike often can not eat at once all the food it captures. In such a case it may impale it upon a thorn for a later meal. The thorn likewise serves to hold the food while the bird. pulls it to pieces. The bird seems to be unable to hold its food beneath its foot and get sufficient leverage to pull it to bits.

\section{Skimmer, Black (Rynchops nigra)}

An occasional summer visitant off the shores of Long Island. There arc only a few definite records of it within the State.

Nu SkB1 Adult on Nest among Sea Rocket Plants (Cakile edentula) on Sandy Beach. Wreck island, Va. (June 28, 1911)

Harper

The appearance of the bird on the ground scarcely suggests that it is one of the most graceful of all birds in flight.

Nu SkB3 Nest with Three Eggs in the Sand; Sea Rocket Plants (Cakilc edentula). Wreck island, Va. (June 26, 1911)

Harper

The nest is merely a scooped-out hollow in the sand on the sea-beach. While incubating, the bird frequently rests its awkward looking, razor-edge bill on the sand, thus making the grooves which appear radiating from the nest.

\section{$\mathrm{Nu} \quad \mathrm{SkB8} \quad$ Adult in Flight}

Can you suggest how the strange bill is used? Does the bird resemble a tern except for its bill? 


\section{Sora (Porzana carolina)}

Also called Carolina rail. The sora and the Virginia rails are the most abundant rails in this State, being especially common in the marshes of central New York and the Great Lake region. It breeds throughout the State.

Call no.

Nu So Adult, Side View, Approaching Nest in Reeds. Renwick, near Ithaca. (June 3, 1914) Allen

Describe its characteristic habitat.

Nu So2 High W'ater Nest with Eggs. Branchport. (May 28, 1914)

Burtch

Water usually covers the site of the nest. In the spring of 1914 the marsh was flooded and this nest was built up more than usual.

$\mathrm{Nu}$ So3 One Young Bird and Several Unhatched Eggs in Nest in Recds. Renwick swamp, near Ithaca. (June 3, 1914)

Allen

Note how the sedges are roofed over the nest to protect it from above. Those in front have been pressed aside to give a clear view of the eggs. The usual number of eggs is eight to ten, but as many as sixteen are sometimes found. A very young sora has a curious red knob or "cere" above the bill and a tuft of orange "whiskers" below the chin, which the Virginia rail does not have.

$\mathrm{Nu}$ So4 Young Bird Shaking Herself. The marsh at Branchport. (July 26, 1911)

Burtch

Nu So5 Young Bird Frightened and Running through the Water. The marsh at Branchport. (July 30, 1911) Burtch

$\mathrm{Nu}$ So7 Adult Feeding along Bank of Stream. (August 18, 1915)

Bailey

Note the long toes. Of what use are they? Compare the bill with that of the Virginia rail.

\section{Sparrow, Chipping (Spizella passerina passerina)}

The most sociable of the sparrows. It feeds on the very porches of houses and builds its nest on the trellises at the side of the house as well as in the shrubs and young evergreens. Unfortunately the house cat feeds upon the young and oftentimes 


\section{Sparrow, Chipping (continued)}

pounces upon the confiding parents. This bird is very useful to the farmer and the gardener for it eats large numbers of harmful insects, such as caterpillars, grasshoppers and leaf-eating beetles; also weed-sceds, such as chickweed, ragweed and dandelion. It has been seen to bring as many as 70 caterpillars to feed to four young birds in an hour and a quarter.

Call no.

$\mathrm{Nu}$ SpC A Pair of Adult Birds on Feeding Station. (1914) Bailcy

When these birds first arrive from the south, they will feed upon seeds put out for them. Distinguished from most other sparrows by its unstreaked ashy breast and chestnut cap.

Nu SpC2 Nest with Four Eggs of Chipping Sparrow and One Egg of Cowbird. (1909)

Built of rootlets; always lined with horse hair.

Nu SpC3 Male with Food, on Back of Nest with Two Eggs of Sparrow and One of Cowbird. (June 1915)

Allen

The male has returned to feed the female, who should be incubating but has been frightened away by the photographer.

$\mathrm{Nu} \quad \mathrm{SpC}_{4} \quad$ Adult and Two Young Birds

Bailey

Note the streaked breast of the young. There are usually two broods a season.

See nest of chipping sparrow with a young cowbird in it, $\mathrm{Nu} \mathrm{Co} 4$.

Nu SpC6 Adult Fceding Young Cowbird. Hamburg. (July 1910)

Allen

It is very probable that the young of the sparrow died. Why?

\section{Sparrow, Field (Spizella pusilla pusilla)}

Associated with the towhee and the indigo bird in the sparsely wooded hillsides, ravines, berry patches and neglected gardens, this pleasant singer leads the company. Most of them pass the winter from New Jersey south. This sparrow is not seen about the house as often as are the song and the chipping sparrows. 5.5 
Call no.

\section{Sparrow, Field (continued)}

Nu SpF1 Adult at Nest in Bush, Young Birds. (1910) Bailey

As a rule, two broods are raised. Observe the pink bill and absence of a black line through the eye. This species is otherwise similar to the chipping.

Nu SpF2 Nest with Four Eggs of Ficld Sparrow and One of Cowbird in the Grass

Bailcy

The cowbird's egg is much larger and more finely speckled than the field sparrow's. The nest for the first brood is often built on the ground at the foot of a bush, but the later nest is regularly in a bush.

Nu SpF3 Nest with Two Eggs of Ficld Sparrow and Onc of Cowbird, in Clump of Jerscy Tea. Corncll heights, Ithaca. (June 1915)

Allen

Sparrow, Fox (Passerella iliaca iliaca)

The fox sparrow resembles the song sparrow but is larger and more brightly colored. The color patterns and spotting of the breast, however, are very similar.

$6.75-7.5$

Nu SpG Adult Feeding on Grain Thrown onto the Snow. Branchport. (March 26, 1916)

Burtch

Sparrow, Grasshopper (Ammodramus savannarum australis)

Nu SpH3 Nest with One Egg (left); Nest Remodeled by Bumblebees (right). McLean. (Junc 1917)

Allon

The bumblebee ordinarily utilizes the nest of a field mouse.

Sparrow, Henslow (Passerherbulus henslowi henslowi)

Rare and of local occurrence in New York. Only the experienced student of birds is likely to find this sparrow.

Nu SpJ2 Nest with Four Eggs in Meadow. South Danby. (July 6, 1917)

Allen

Note daisies, hawk weed and ripe strawberries.

Nu SpJ3 Female Incubating. South Danby. (July 6, 1917) Allen

Note the conspicuous light bill and the small tail. 


\section{Sparrow, House (Passer domesticus)}

The house sparrow, commonly known in this country as the English sparrow, was brought from Europe and liberated in Brooklyn, 1860-64, and has since spread over the whole country.

Nu SpI Male (right) and Female on Stump. Renwick, ncar Ithaca. (April 13, 1915)

Allen

The male is recognized by its black "bib." During the fall and winter months this is not clearly noticeable because each black feather is elged with gray. In the case of this male the gray tips have not yet worn off enough to make the bib heary.

Nu SpI1 Male, in Full Summer Plumage, and Female on Stump. Ithaca. (June 10, 1914) Allen

Observe the conspicuous black throat patch and compare with picture taken in April. The difference is due entirely to "feather wear."

Nu SpI6 Three Females Figliting at Feeding Station. (May 14, 1914)

Allen

The house sparrows differ from our native birds in that they come close together to feed, but they frequently quarrel in consequence. Note the typical sparrow bill.

Nu SpI8 Eight Adults on Branch of an Evergrecn. (February 1914)

Allen

These birds are waiting near a station to be fed. Which are males and in what plumage are they?

See also house sparrow in contest with tree sparrow Nu SpT8

$\begin{array}{lll}\text { “ with chickadee at feeding station } \\ \text { “ } & \text { Nu Ci94 } \\ \text { “ } & \text { and cowbird } & \mathrm{Nu} \mathrm{Co8} \\ & \text { being charged by a grosbeak } \\ \text { “ } & \text { and song sparrow } & \mathrm{Nu} \text { GtE8 } \\ \text { “ } & \text { being attacked by nuthatch } \mathrm{Nu} \text { NuW9 }\end{array}$


Sparrow, Savannah (Passerculus sandwichensis savanna)

This sparrow is seldom seen about trees. It prefers open fields and is seldom seen off the ground except as it sometimes perches upon fence posts and rail fences. It nests on the ground.

Call no.

$\mathrm{Nu} \quad \mathrm{SpP} \quad$ Adult on Perch near Nest, Front View. (Junc 2, 1915)

Allon

To be distinguished from the song sparrow by not having the spot on the breast so prominent and also by the yellow line over the eye and through the crown.

Nu SpP1 Adult on Percl with Food, Back Vicw. (1908) Bailey

Note short tail. Upper parts streaked and darker than those of the vesper sparrow. Half of its food consists of insects, mainly injurious.

Nu SpP3 Female Incubating. Ithaca. (May 18, 1915) Allen

Note the protective coloration. How is this accomplished?

Nu SpP4 Three Young Birds Posed on Perch. (1908)

Bailey

Immature birds do not have the yellow line over the eye and are much darker. Note bunches of down on head.

\section{Sparrow, Seaside (Passerherbulus maritimus maritimus)}

Nu SpQ Adult on Ground in Marsh Grass. Long Beach. (October 25,1908 )

Harper

The picture shows the bird in its favorite haunt. In skulking about over the muddy ground in the salt marsh, it has paused for a moment to look at the camera.

\section{Sparrow, Song (Melospiza melodia melodia)}

Next to the robin this is the commonest native bird in New York State. It prefers moist land near water but is found wherever there are bushes or undergrowth. It is at home in rich, moist gardens. It is a resident of New York but is common in winter only about New York City and the lower Hudson. About half its food consists of weed seeds. It eats also many injurious insects and some fruit, mostly wild. 
Call no.

\section{Sparrow Song (continued)}

Nu SpR Song Sparrow (left) and House Sparrow (right) Facing Each Other for a Fight. (October 17, 1914) Bailey

Nu SpR1 Male and Female at Feeding Station. Ithaca. (May 1917) Allen

Both sexes of this species are alike in appearance.

\section{Nu SpR2 Nest with Five Eggs in a Bush}

The nest is sometimes built in a bush, more often on the ground, especially the bank of a brook or ditch, rarely in a tree. The outer layer is of grasses and straws, the inner layer of fine grasses and horsehair.

Nu SpR3 Nest with Four Eggs Showing Maximum Variation in Color and Markings. Cornell University Zoological Museum. (1910)

Nu SpR4 Three Young Birds Posed on Small Limb. (1900)

Do they resemble their parents?

Nu SpR5 Adult with Food and One Young Bird on Perch. Arcade. (1906)

R. H, Beebe

What kind of food has the bird in its bill?

Nu SpR6 Adult Feeding Worm to Young. (1903) Bailey

Nu SpR7 Adult on Ground. (1909) Bailey

A good example of protective coloration. Note the spot on the breast. This is a distinguishing mark. Compare with the swamp sparrow as to breast markings. These birds are frequently confused.

Nu SpR72 Adult with White-throated Sparrow on Ground at Feeding Station among Saxifrage and Hepaticas. Ithaca. (May 10, 1917)

Allen

Nu SpR8 Adult Feeding in Snow. (1911)

Bailcy

Sparrow, Swamp (Melospiza georgiana)

As indicated by its name, this bird is essentially a resident of swamps. Many are found in the Montezuma marshes, but nearly all our smaller swamps have a few. What effect does the drain- 


\section{Sparrow, Swamp (continued)}

ing of marshes have on the range of this bird? To the careless observer, it appears to be colored much the same as the song sparrow. Its breast, however, is almost unstreaked. The songs of the two birds are decidedly different.

Call no.

$\mathrm{Nu} \mathrm{SpS}$ Adult Singing on Stem of Sedge. Renwick flats, near Ithaca. (June 13, 1909)

Allen

This bird usually sings from such a perch. Why does it sing? Compare throat-patch with that of the white-throated sparrow.

Nu SpS2 Nest with Four Eggs in Dried Sedges. Renwick, near Ithaca. (June 1910)

Allen

Nu SpS3 Nest with Four Eggs Showing Unusual Variation in Markings. Renwick, near Ithaca. (June 15, 1914) Allen

The eggs of the swamp sparrow are normally very heavily speckled with brown.

\section{Sparrow, Tree (Spizella monticola monticola)}

A common winter resident. For the most part it travels in flocks feeding upon the weeds along highways, in yards, and on edges of woodlands. It is of great value as a weed-seed destroyer. It nests far north in Canada.

6.36

Nu SpT Two Adults on a Stump. (March 30,1915)

Allen

The upper bird shows the characteristic single spot in the middle of the breast; the lower the conspicuous wing bars.

$\mathrm{Nu}$ SpT8 Contest between a Tree Sparrow and a House Sparrow at a Feeding Station. Genesco: (1915)

Bailey

Notice the wing bars on the tree sparrow. Which bird appears the more frightened?

\section{Sparrow, Vesper (Poxcetes gramineus gramineus)}

The vesper sparrow, or bay-winged bunting, is one of the larger sparrows and generally distributed over the State. It prefers open grassy fields. It is seen also on plowed ground and along dusty roads. It sings early in the morning and late in the evening. The song of several birds from different directions is 


\section{Sparrow, Vesper (continued)}

extremely enjoyable. The appearance of the white outer tail feathers of this bird, which show when it flies, enables one to identify it.

$5.8-6.7$

Call no.

$\mathrm{Nu} \mathrm{SpV}$ Adult on Mullein Stalk with Cutworm in Its Bill for Young. Corncll heights, Ithaca. (July 14, 1915) Allen

The cutworm is one of the most destructive of all caterpillars.

Nu SpV2 Nest with Four Eggs in Grass and Thistles, a Caterpillar

Built in a deep depression, of simple construction.

Nu SpV3 Adult Incubating on Nest in Grass. (May 1913) Bailey

The nest is invariably on the ground. Two broods are reared a season. Which is this one?

Nu SpV4 Adult with Three Young Birds. Cornell heights, Ithaca. (July 14, 1915)

Allen

The young more than fill the nest, which is placed in a depression in front of a clover plant.

\section{Sparrow, White-crowned (Zonotrichia leucophrys leucophrys)}

Like the white-throated sparrow, this bird is seen only at migration time. It arrives from the south a little later than the white-throats. It does not nest in New York. It is quite approachable.

$6.75-7.5$

Nu SpW Adult Fccding, Side View. (1912)

Bailey

Larger than the house sparrow. Black crown with broad white stripe through the center, only partly seen here; a white stripe beginning just above the eye and reaching backward until it joins the central stripe, a black line through the eye; making in all 4 black and 3 white stripes. The head is thus conspicuously striped. It is to be distinguished from the white-throated sparrow by the absence of a white patch on the throat and the difference in crowns. 


\section{Sparrow, White-throated (Zonotrichia albicollis)}

Also from its song called the Peabody bird. In the spring and again in the fall this interesting bird is common along the roadside and hedges. It nests in the north and the colder parts of the State and is one of the commonest birds of the Adirondacks. It passes the winter in the southern states. This bird is gregarious in habit and very sociable.

$6.6-6.8$

Call no.

Nu SpX Adult on Feeding Limb. (May 1912)

Bailey

$\mathrm{Nu} \mathrm{SpX2}$ Nest with Four Eggs on Hummock in Bunch of Weeds. Edge of Potters swamp. (June 6, 1909) Stone

$\mathrm{Nu}$ SpX3 Nest with Three Eggs in Clump of Bunch-berry Plants in Blossom. Cranberry lake. (June 28, 1916) Bailey

See adult with song sparrow, Nu SpR72.

\section{Swallow, Bank (Riparia riparia)}

This swallow is abundant in certain sections of the State, particularly where favorable sandbanks abound. At first it built its nest along the banks of streams, but now takes advantage also of banks formed by roads, sand pits and railroad cuts. Late in the summer it congregates in large numbers on telegraph and telephone wires.

Nu SuB Adult on Perch near Nest. Near Ithaca. (June 1915)

Observe the band across its breast distinguishing it from rough-winged species.

Nu SuB2 Nest and Section of Burrow. Near Ithaca. (July 1915)

Allen

The bank was cut away to show the burrow and nest at its end. Note the downward trend of the burrow for drainage. The burrow is from $1 / 2$ to 3 feet long, enlarged at the back end to accommodate the grass and feathers of which the nest is made. The entrance is a flattened ellipse from 2 to $2 \frac{1}{2}$ inches across.

Nu SuB3 Nesting Site of a Colony of Birds

Notice the number of holes in the bank. 
Call no.

\section{Swallow, Bank (continued)}

Nu SuB4 Several Nest Entrances in Sandbank, Near View

A pair of birds has a nest at the end of each burrow.

Nu SuB6 Five Adults Hovering before Nests

Allen

Note the various positions of the wings. Are the wings used for anything but propulsion? Their shape is characteristic of swallows.

\section{Swallow, Barn (Hirundo erythrogastra)}

The most generally distributed swallow of New York. This species is very beneficial, being insectivorous, but not uncommonly the farmer unwisely knocks down the nest built in his barn and sheds.

$6-7$

Nu SuC Adult Resting on Perch. (September 1914)

Bailey

This perch was used as a resting place between flights over the pond near by. A distinguishing feature of the barn swallow is the forked tail, the outer feathers showing like knitting needles.

Nu SuC2 Nest of Mud and Straw Attached to Beam Supporting Ceiling in Old Barn. Near Pembina, N. D. (June)

Peabody

Nu SuC4 Adult with Wings Fluttering, before Nest with Young. (June 1915)

Allen

This photograph was made by flashing light from a mirror through a crack in the barn. Observe the size of the mouth.

\section{Swallow, Cliff (Petrochelidon lunifrons lunifrons)}

Found in sparsely settled portions of the State, especially the Adirondacks and Catskills. It is not only a very interesting bird but also a very useful one. It seems to be disappearing from New York, however, partly from the disposition of farmers to encourage the destruction of its nests.

$5-5.5$

Nu SuE2 Many Nests along Side of Cliff. Idaho

Hamilton

This is the natural nesting site of this bird. 
Call no.

\section{Swallow, Cliff (continued)}

$\mathrm{Nu}$ SuE3 Four Nests under the Eaves of a Barn. Chazy. (June 1, 1918)

Allen

An acquired nesting site. Note shape of nest with opening just large enough to admit the bird.

Swallow, Rough-winged (Stelgidopteryx serripennis)

It resembles the bank swallow, but is larger. It inhabits river valleys and lake shores. It appears to be extending its range. It nests in shale rock, stone bridge abutments and old burrows of the kingfisher.

5.5-5.7

Nu SuR Male and Female Perched on Twig. Ithaca. (June 20, 1913)

Allen

The perch is near the nest and is the same one occupied by the kingfisher, $\mathrm{Nu} \mathrm{KiB}$.

Nu SuR5 Adult and Six Young on Fence Wire. Ithaca. (June 22, 1913)

Allen

\section{Swallow, Tree (Iridoprocne bicolor)}

The tree swallow is of more or less local distribution. In marshlands and near bodies of water, it is found nesting in holes, on limbs or in nesting boxes. It is especially common in the central lake region and around the lakes of the Adirondacks, where there are many dead tree stumps, and in western New York, where it takes kindly to nesting boxes. Another name for this bird is white-bellied swallow.

Nu SuT Adult on Perch near Nest. (1910)

Bailey

Nu SuT2 One Bird Looking Out of Nest Hole in Willow Tree, Another on the Tree before the Hole. Ithaca. (1909)

Harper

These birds took possession of what had doubtless been an old downy woodpecker nest. The nest was 5 or 6 feet above the ground. The tree swallow likewise utilizes nesting boxes placed on poles above buildings.

Nu SuT3 Adult with Feather in Bill, at Nest Hole. (June 1915) 
Call no.

\section{Swallow, Tree (continued)}

Nu SuT4 Large Young Bird on Perch. (1912)

Bailey

Nu SuT5 Adult and Five Young Birds on Limbs of Dead Tree. West marsh, near Ithaca. (June 21, 1908) Allen

These young birds have been removed from the nesting hole. The young at this age are fed like ordinary birds: namely, the old bird alights and places food far down the throat of the young.

Nu SuT54 Adult on Wing Feeding a Young Bird. Renwick, near Ithaca. (June 19, 1911)

Allen

After the young birds leave the nest the old bird never alights to feed them, but swings past and drops the food into the open mouth.

Nu SuT6 Adult Flying to Its Nest in a Hole in a Dead Stub of Tree. Near Ithaca. (June 26, 1915) Allen

The bird is checking its flight, turning before alighting. Observe the position of the tail.

Nu SuT8 A Multitude of Swallows, Largely Tree, on Telegraph Wires. Montezuma marshes. (July 31, 1915)

Preparatory to their southern migration swallows gather in large flocks and for weeks at a time they frequent certain points while their numbers continue to increase by fresh arrivals. Note the date of the picture.

\section{Swift, Chimney (Chcetura pelagica)}

While ordinarily called a swallow, the swift is more nearly related to the nighthawks. In former times this bird nested in hollow trees. Now, with the advent of man, it uses the chimneys and barns for nesting sites. It is never on such perches as fence posts or telegraph wires. If it alights, it does so on some vertical surface. It may be noticed in flight early in the morning or late in the afternoon.

$4.8-5.6$

Nu SwC2 Nest with Five Eggs. (July 1906) Bailey

Notice the materials that compose the nest. The twigs are broken off by the bird while flying; they are cemented together by a gelatinous substance secreted by the salivary glands of the bird. The nest is not lined. 
Call no.

\section{Swift, Chimney (continued)}

$\mathrm{Nu}$ SwC3 Nest with Four Eggs in Chimney, Seen from Top of Chimney

Stone

Nu SwC4 Nest Filled with Young Birds. (July 1906)

Bailey

Notice the crowded condition of the nest. The eyes of the young birds are still closed, and the eyelids bear feathers. Note the size of the mouth.

Nu SwC5 Adult Crowding the Young Birds from Nest. (July 1906)

Bailey

When nearly fledged the young are compelled by the adult birds to cling to the wall to which the nest is attached. Note the long wings of the adult bird. The spines of the tail show on one young. What is their use?

$\mathrm{Nu}$ SwC6 Adult with Young Clinging to Wall, One Bird Still in Nest. (July 1906)

Bailey

Note the size of the mouth, the long wings, short tail and spines on tail. Observe how all four toes are directed forward.

\section{Tanager, Scarlet (Piranga erythromelas)}

The most brilliantly colored of our summer birds. The female is dull colored, while the male, with the exception of the wings and tail, is deep scarlet. Found in every county of the State, but not anywhere except in forested districts, large groves and wooded ravines.

$7-7.3$

Nu TS3 Female Inspecting Nest in Oak Tree on Branch Covered by Grapevine; Birds in Nest. Ithaca. (July 18, 1919)

Allen

Nu TS35 Male Feeding Young on Branch of Tree. Ithaca. (July 22, 1919) Allen

For map showing distribution and migration of this bird, see $\mathrm{Nu}$ ZM7, p. 166.

\section{Teal, Green-winged (Nettion caralinense)}

More common along the Hudson and the lakes and marshes of the interior of the State than along the coast. Chiefly a migrant. It feeds chiefly at night on aquatic plants, snails, insects and crustaceans. 
Call no,

\section{Teal, Green-winged (continued)}

Nu TeG Male on Plank (captive). Ithaca. (June 25, 1918) Allen

Nu TeG1 Banded Female on Plank (captive). Ithaca. (June 25, 1918)

Allen

Tern, Black (Hydrochelidon nigra surinamensis)

A fairly common migrant about the lakes of the State in the fall. It occasionally nests in Montezuma marshes and is a regular summer resident near Big Sandy creek in Jefferson county, where there are nests by the score. The adults stick close when one handles the young.

9-10.25

Nu TfB Adult on Nest, One Young at Side

Chapman

Note the black head and neck.

Nu TfB2 Nest with Three Eggs on Ground. Sandy creek, Jefferson co. (June 13, 1915)

Bailey

Nu TfB3 Nest with Two Eggs, Surrounded by Water; Onc Young Bird Leaving Nest. (June 25, 1915)

Bailey

The young are precocial.

Nu TfB6 Adult in Flight, in Fall Plumage. Branchport. (September 3,1911 )

Burtch

Note the long wings. In flight this tern resembles the nighthawk in size, color, wing stroke and the habit of hawking over marshes for insects. What is the difference between its spring and fall plumage?

Nu TfBg Adult as It Strikes Straw Hat of Man in Tall Grass

The black tern is noted for its daring.

Bailey

\section{Tern, Caspian (Sterna caspia)}

Along the Great Lakes and on Long Island this bird is found now and then in the fall. It is not known to nest within the State, but nests both north and south of the State. Like the black tern, it nests in colonies.

20-23.5

Nu TfC Hundreds of Caspian Terns and Gulls on the Ground and in the Air at Nesting Site. Georgian bay, Canada. (July 6, 1912) Bailey 
Call no.

\section{Tern, Caspian (continued)}

$\mathrm{Nu}$ TfC2 Nest with Two Eggs on Ground. Georgian bay, Canada. (July 6, 1912) Bailey

Its nest a mere depression in the ground; eggs protectively colored.

Nu TfC6 Several Adults in Flight. Georgian bay, Canada. (July 6, 1912)

Bailey

Note the long narrow wings for gliding.

\section{Tern, Common (Sterna hirundo)}

Along Long Island this bird is fairly common, especially as a transient. It nests on Gardiners island and Fishers island, where wardens of the Audubon societies give it ample protection. It is not known to nest farther up the State.

13-16

$\mathrm{Nu}$ TfD Adult with Wings Upraised Alighting at Nest on Stony Beach. Gardiners island. (June 11, 1911) Harper

$\mathrm{Nu}$ TfD2 A Pair of Adults at Nest on Beach. Gardiners island. (June 19, 1911)

Harper

The black cap, pointed bill and long forked tail distinguish terns from gulls. The male is very attentive and often stands by his mate while she is incubating. These birds belonged to a good sized colony nesting on the beach. Within a few feet there were several other nests. Note the sharp-pointed bill for spearing small fish.

Nu TfD3 Nest with Two Unhatched Eggs and One Young Bird. Georgian bay, Canada. (July 6, 1912) Bailey

Eggs are laid in a mere depression in the sand or in rubbish or seaweeds. Though just hatched the young birds make a pretense of defense.

See also terns and gulls, $\mathrm{Nu}$ GrH9.

\section{Tern, Gull-billed (Gelochelidon nilotica)}

A southern species that is accidental on the coast of New York.

Nu TfG Adult on Nest among Bivalve Shells on Shore. Cobb's island, near Virginia

Chapman

Note the heavy bill. 


\section{Tern, Sooty (Sterna fuscata)}

A bird of the seashore and lake region, not common inland. In tropical countries, to which it belongs, its eggs are eaten. The bird is an accidental visitor in New York State. In 1876 and 1878 a large number came north and several were observed in this State.

$15-17$

Call no.

Nu TfS Adult on Nest

$\mathrm{Nu}$ TfS7 Two Adults in Flight

Notice the position of the feet and of the wings. A good flight study.

\section{Thrasher, Brown (Toxostoma rufum)}

The range of this bird coincides closely with that of the catbird, though it is less common. It frequents hedgerows, thickets and hillside pastures, preferably those removed from habitations of man.

$11.5-12$

Nu ThB5 Adult (wounded) in Crotch of Tree. (1898)

Notice the long beak and the color and expression of the eye and compare with the wood thrush.

Nu ThB2 Adult on Nest. Piffard. (July 10, 1917)

Bailey

Note length, size and form of tail and bill.

Nu ThB6 Adult Perched on Post, Side View. Arcade. (1905)

R. H. Beebe

Thrush, Olive-backed (Hylocichla ustulata swainsoni)

One of the last birds to arrive during the spring migration, usually after the middle of May. It nests only in the Adirondacks and Catskills.

$7-7.5$

$\mathrm{Nu}$ TiO Adult on Edge of Nest. Cranberry lake. (July 1, 1916)

Bailey

Nu TiO2 Nest and Egg in Snall Beech Tree. Cranberry lake. (July 1, 1916)

Bailey 


\section{Thrush, Wood (Hylocichla mustelina)}

The prominent spots on the breast make the identification of this wood bird easy. Early in the year the wood thrush feeds upon insects, but later upon berries. It seems to become rather easily adapted to civilization and in some places is found about houses.

Call no.

$\mathrm{Nu}$ TiW Adult at Nest Inspecting Young after Feeding. Ithaca. (July 1, 1911) Allen

Compare the spots on the breast with the fainter spots of the veery. What are the characteristics of the bill of the thrush?

Nu TiW2 Nest Containing Two Eggs of Thrush and One of Cowbird. (June 5, 1915)

Bailey

Notice that the nest resembles that of a robin, having an outer layer of grasses, an inner layer of rootlets and a middle layer of mud. It is usually placed in a sapling or on the limb of a tree, some distance above the ground. It is very unusual for the cowbird to select the nest of a bird larger than itself.

Nu TiW3 Two Young Thrushes in Same Nest as in Nu TiW2. (June 19, 1915)

Bailey

This picture and the preceding one show that the cowbird is not always the bird that survives.

Nu TiW4 Adult Incubating, Side Vicw; Nest in Elm Sapling. Ithaca. (June 20, 1911) Allen

Nu TiW5 Adult at Nest with Second Brood; Bottom of Nest Ornamented with Large Piece of Paper. Ithaca. (August 1, 1917) Allen

Nu TiW6 Adult on Edge of Nest "Frcezing," Front Vicw. (1911)

Note how deep the nest appears to be.

Bailey

Towhee (Pipilo erythrophthalmus erythrophthalmus)

A bird of the second growth timberland. It usually nests on the ground and the young run about at an early age. It feeds principally upon the ground. During the migration season it is often seen in the dooryards and gardens. Another name for this bird is chewink. 
Call no.

\section{Towhee (continued)}

Nu Tp Adult on Log near Nest, Side View, (1912)

Bailey

Note the long, widespread tail, carried upward.

$\mathrm{Nu} \quad \mathrm{Tp} 2 \quad$ Nest with Four Eggs on Ground. (1912)

Bailey

A typical nesting place at the foot of a plant.

Nu Tp5 Adult at Nest Feeding Young. Arcade. (1905)

Note the suspicious manner of the adult.

R. H. Beebe

Veery (Hylocichla fuscescens fuscescens)

Known also as Wilson's thrush. This bird prefers damp woods, especially a swampy forest that is flooded early in the season.

$7-7.5$

$\mathrm{Nu} \mathrm{Ve}$ Adult Incubating. (1910)

Bailey

Notice the small spots on the breast. The wood thrush has large spots. The nest is usually placed on or near the ground, sometimes an a $\log$.

Nu Ve2 Nest and Four Eggs with an Egg of the Cowbird. Ithaca. (June 1915)

Allen

Note how the nest is built up from the ground on a platform of leaves.

Nu Ve4 Adult with Young in Nest. Renwick, near Ithaca. (June 5, 1915)

Allen

The young are ready to be fed, but this time the old bird has no food.

Nu Ve6 Adult on Nest Panting. Renwick, near Ithaca. (June 5, 1915)

Allen

The bird is protecting the young from the heat of the sun.

Vireo, Blue-headed (Lanivireo solitarius solitarius)

A summer resident of the Canadian zone of New York. This species is known also as the solitary vireo. It breeds in deep cool woods, more frequently in evergreens.

$5.25-5.75$ 
Call no.

\section{Vireo, Blue-headed (continued)}

$\mathrm{Nu}$ ViB Adult Incubating, Nest Hanging to Hemlock Limb. Ithaca. (May 31, 1914)

Allen

Nu ViB2 Nest with Two Vireo and Two Cowbird Eggs in Hemlock Tree. Beebe lake, near Ithaca. (May 25, 1913) Allen

Note the occurrence of this bird in western New York and read the report of Eaton, Birds of New York, vol. 2, p. 374.

Nu ViB3 Nest with Cowbird Egg in Hemlock Tree. Ithaca. (May $25,1913)$

Allen

This cowbird egg was kept from hatching by a floor built over it by the vireo.

Nu ViB4 Nest on Hemlock Twig, and Young Cowbird. Ithaca. (June 16, 1914) Allen

This is the same nest as shown in Nu ViB3. After the floor was built three vireo and two cowbird eggs were laid in the nest. This young cowbird is the sole survivor.

Nu ViB6 Adult in Nest in Hemlock Tree, a Man's Hand Almost Touching It. Ithaca. (May 19, 1913) Allen

The bird knew no fear while incubating, so that one could pull down the branch and stroke the bird.

\section{Vireo, Red-eyed (Vireosylva olivacea)}

The commonest of the vireos of New York, uniformly distributed. It is arboreal in habit. It sings from the tree top throughout the day.

$6-6.25$

Nu ViR Adult Repairing Nest into Which an Egg Has Been Laid. Renwick, near Ithaca. (June 1910)

Allen

The nest is supported largely by cobwebs. The material of which it is made becomes loosened as incubation advances and the nest frequently has to be repaired continuously.

Nu ViR2 Nest with Three Vireo Eggs on Top of Two Cowbird Eggs

Notice the manner of weaving the nest and also its position. The nest is regularly suspended from a forked twig in a bush or low limbed tree.

For picture of nest with cowbird in it, see $\mathrm{Nu}$ Co44. 
Call no.

\section{Vireo, Red-eyed (continued)}

$\mathrm{Nu}$ ViR3 Adult Inspecting Nest with Young. Silver lake. (1907) R. H. Beebe

Nu ViR4 Adult near Nest Feeding Young Bird. (1910) Bailey Note the character of the nest.

Nu ViR5 Adult with Wild Berry, One Young Bird on Twig, Two in Nest. Ithaca. (1909)

Bailey

These birds destroy many insects and are highly beneficial. They likewise eat wild fruits.

Nu ViR6 Adult with Caterpillar for Young in Nest and on Branch. Ithaca. (1908)

Bailey

Note the red iris, the white stripe over the eye and the blackish line through the eye.

Nu ViR7 Adult Perched on Twig before Young with Flapping Wings. Silver lake. (1907)

Beebe

This young bird was placed upon the perch by the photographer. Its effort to fly is stimulated by the presence of the mother bird.

\section{Vireo, Warbling (Vireosylva gilva gilva)}

The warbling vireo is more a bird of the villages and yards than are the other vireos. It has a beautiful warbling song.

$5-5.6$

Nu ViV2 Nest with Two Eggs, Suspended from Limb. Pueblo, Col. Nash

Notice the manner in which the nest is made and also its position.

Nu ViV4 Two Young Birds About to Fly

Vireo, White-eyed (Vireo griseus griseus)

More common on Staten island and Long island and in the lower Hudson valley than elsewhere in the State.

$5-5.3$

Nu ViW2 Head of Adult Projecting above Hanging Nest Built in Blackberry Bush

This is a typical place for the nest, which is regularly built near the ground. Note especially the composition of the nest and compare it with the nest of the red-eyed vireo. 


\section{Vireo, Yellow-throated (Lanivireo flavifrons)}

A common summer resident except in the Adirondacks and Catskill districts. A bird of the tree tops. Keeps to the denser foliage.

$5.75-6$

Call no.

Nu ViY1 Adult with Food on Perch. Ithaca. (July 15, 1917)

Bailey

This is the only vireo with a yellow throat. The bill is typical of vireos.

Nu ViY3 Adult Incubating in Nest in Chestnut Tree, 20 Feet from Ground. Ithaca. (June 3, 1915)

Allen

Note how the outside of the nest is "ornamented" with bits of cobwebs.

\section{Vulture, Turkey (Cathartes aura septentrionalis)}

This useful scavenger is of uncommon occurrence in New York but is very abundant farther south, where it feeds upon dead animals and refuse. The bill and feet are not so strong as those of other members of the hawk family.

26-32

Nu VuT Vulture on Stump, with Wings Spread, Side View. Washington, D. C. (April 4, 1915)

Allen

The naked red head gives the species the name of turkey vulture. This bird has just alighted and has not yet closed its wings.

Nu VuT4 Two Vultures, Back of One with Wings Spread. Washington, D. C. (April 4, 1915)

Allen

Vultures are fond of sunning themselves in this way and spend the early mornings "drying the dew from their feathers." The bird on the ground is tearing up a dead chicken.

Nu VuT6 Wounded Bird on Fence, Head in Profile. (July 25, 1915)

Bailey

Notice the naked head, hooked bill and large but wreak feet.

Nu VuT8 Several Adults on the Shore and in Flight. Beaufort harbor, N. C. (August 31, 1913)

Harper

Gathered on the shoal to pick over some bones lying there, they were taking wing at the approach of a boat. The wings are broad for soaring. 


\section{Warbler, Blackburnian (Dendroica fusca)}

A common summer resident in the Adirondacks and Catskills, but it breeds locally also in cooler situations in central and western New York. Found about lawns and parks during migration; in mixed and evergreen forests during nesting season.

5.25

Call no.

Nu WA3 Adult on Nest in Hemlock Tree. Tully. (June 16, 1917)

Bailey

This nest was 25 feet from the ground, which is rather low for this species.

Nu WA8 Adult Remaining on Nest When Touched by Finger of a Man. Tully. (June 16, 1917)

Bailey

Shows lack of fear of this bird when the eggs were about to hatch.

\section{Warbler, Black-throated Blue (Dendroica caerulescens caerulescens)}

A transient or a summer resident of every part of the State; a common summer resident of the Adirondacks and the Catskill region. It prefers woodlands.

Nu WB Adult Female on Perch, Side View, Photographed by Allen (July 23, 1915); Inset of Male from Mounted Specimen, New York State Museum. (1919)

This perch was near the nest. The spot on the wings is a distinguishing mark. Notice the fine forceps-like bill, characteristic of all the warblers.

Nu WB2 Nest with Four Eggs in Ground Hemlock. McLean. (June 11, 1915)

Allen

This nest was 18 inches from the ground. This low position is characteristic. The nest is neat, compact and thick walled with many fragments of decayed wood in its foundation.

\section{Warbler, Canada (Wilsonia canadensis)}

During migration season, found about yard shrubbery and the thickets along streams and woodlands. It is common in the Adirondacks and the Catskills during the summer. 
Call no.

\section{Warbler, Canada (continued)}

Nu WC Adult Male on Log with Cranefly for Young on Ground. Michigan hollow, near Ithaca. (June 18, 1911) Allen

Note the well-defined necklace of black streaks, characteristic of the male. The young bird has left the nest. Note the moss, ferns and other evidences of moist woodland.

\section{Warbler, Cerulean (Dendroica cerulea)}

This bird comes into New York from the Mississippi valley. It breeds in western New York but is rarely seen in the eastern and southeastern parts.

4-4.5

Nu WD1 Adult at Nest (lowered) with Young. Howlands island. (July 3, 1917) Allen

This was built about 80 feet from the ground in a large oak. When the young were ready to fly, the branch with the nest was lowered for photographing.

Nu WD3 Nest and Eggs on Limb Removed from Elm Tree. Potters swamp. (May 31, 1909)

Stone

This nest was about 50 feet from ground.

Nu WD4 Two Young Birds on Nest in Swamp Maple, 25 Feet from Ground. Free bridge, near Cayuga. (June 12, 1915)

Allen

The warbler regularly builds its nest high in trees. Note how these birds are outgrowing the nest.

\section{Warbler, Chestnut-sided (Dendroica pensylvanica)}

One of the most abundant and widely distributed of the warblers. It is partial to slashings and thickets. It is found on the edge of woods, bush pastures and neglected roadsides.

Nu WE1 Male on Edge of Nest in Which Are Two Eggs. McLean. (June 11, 1916)

Allen

The male helps with incubation and care of young.

Nu WE4 Female on Edge of Nest with Young. Labrador hill, near Truxton. (July 7, 1917)

Bailey

Nu WE3 Nest with Four Eggs in Low Bush. (1914)

Bailey 


\section{Warbler, Golden-winged (Vermivora chrysoptera)}

An inhabitant of swamps, thickets and second growth of damp bushy fields.

Call no.

Nu WG Male with Food for Young on Side of Perch. Near Port Byron. (July 3, 1917)

Allen

Note the conspicuous black throat that distinguishes the male.

Nu WG1 Female with Food on Perch. Howlands island, near Port Byron. (July 3, 1917)

Bailey

Nu WG2 Nest with Five Eggs in Clump of Plants. Potters swamp, Branchport. (June 6, 1909)

Stone

This nesting site is characteristic.

\section{Warbler, Magnolia (Dendroica magnolia)}

Common resident in the Canadian zone of the Adirondacks and in the Catskills; breeds sparingly in other parts of the State; a common migrant throughout.

$4.75-5$

Nu WM Male at Nest with Young. Cranberry creek. (June 26, 1916)

Bailey

The nest is usually in a coniferous tree near the ground. It is loose and bulky.

Nu WM1 Female at Nest with Young. Cranberry lake. (July 1, 1916)

Bailey

Nu WM2 Nest with Four Eggs in Dense Foliage of Hemlock Tree. Taghanic falls.

Bailey

This warbler prefers coniferous tree growth as nesting site.

\section{Warbler, Mourning (Oporornis philadelphia)}

Fairly common summer resident in the Catskills and Adirondacks and also the highlands and colder swamps of other parts of the State.

$\mathrm{Nu}$ WN Female Feeding Cankerworm to Young on Perch. Renwick, near Ithaca. (June 17, 1915) Allen

Altricial birds often continue to be fed by the parent for a month or longer after leaving the nest. Note the comparative size of the young bird and the adult. 
Call no.

\section{Warbler, Mourning (continued)}

Nu WN2 Nest with Four Eggs in Clump of Coarse Grass. Branchport. (June 7, 1908)

Stone

The nest is usually placed in the shade in a tangle of briars, ferns, skunk cabbage or nettles. This one is in a boggy place along the edge of woods.

Nu WN4 Female Incubating. Ithaca. (June 1917)

Allen

Note how the nest is built up from the ground among weeds.

\section{Warbler, Yellow (Dendroica astiva cestiva)}

Our common summer "yellowbird." A most useful bird because it frequents orchards and fruit trees in general, feeding upon injurious insects. It nests about houses as well as in woods.

Nu WY Adult Perched over Young in Ncst. (1910) . Bailey

Nu WY2 Nest with Five Eggs in Thicket of Berry Bushes

Notice the compact character of the nest and its position. The nest is usually placed in a shrub or low tree near the ground.

Nu WY3 Adult Taking Cotton for Nest Building. Ithaca. (May 24, 1916)

Allen

One way to attract birds is to place out for them suitable building material.

Water-thrush (Seiurus noveboracensis noveboracensis)

A common summer resident of New York State. In the migration period it may be found frequently at a considerable distance from water. It is not a thrush, but belongs to the warbler family, being closely related to the ovenbird.

$5.5-6$

Nu Wf1 Adult on Mossy Ground among Ferns. Tully lake. (June $25,1917)$ Allen

Nu Wf2 Nest with Two Thrush Eggs and Two Cowbird Eggs in Mossy Bank near the Water. Potters swamp, Branchport. (May 23, 1909)

Burtch

Prefers to build its nest in the cool depths of a wooded swamp near the water. 


\section{Water-thrush, Louisiana (Seiurus motacilla)}

This bird, while really a warbler, has the name thrush. A characteristic feature of the water-thrush is the tilting of its body something after the manner of the spotted sandpiper. The nest is placed on the side of a bank along a stream near the water. As suggested by the name and indicated by the pictures, this thrush prefers wooded sides of streams where the water tumbles over the rocks.

$6-6.3$

Call no.

Nu WfL Adult with Food on Rock beside Rushing Water. Ithaca. (May 28, 1914) Allen

Nu WfL2 Nest with Four Eggs on Bank of Stream. (1910) Bailey

The nest of this bird is usually placed along the side of a brook, in some overhanging ledge behind dangling rootlets.

$\mathrm{Nu}$ WfL4 Young Bird on End of Branch. (1910)

Bailey

Notice the natal down on the head.

Nu WfL5 Adult Fceding Four Young Birds. Ithaca. (May 28, 1914)

Allen

When several are to be fed the mother bird carefully distributes the food. Note the eagerness of the young birds.

\section{Waxwing, Cedar (Bombycilla cedrorum)}

Cedar bird is another name. It is gregarious in habit. It is commonly found both in orchards and shade trees and along the swamps and streams of the Adirondacks. It is called a polite bird. Why? It is beneficial because it eats many insects such as caterpillars and measuring worms, but, like the robin, is destructive of small fruits, especially cherries and berries. 8

Nu Wg2 Adult at Nest Containing Four Young Birds. Cardiff. (July 1913)

Bailey

Notice the crest of the adult. This is raised and lowered at the pleasure of the bird. What other birds have a crest? Note also the thick neck. The bird has her throat filled with choke cherries so that each young bird will be fed at this visit. The cherries are regurgitated one at a time. 
Call no.

\section{Waxwing, Cedar (continued)}

Nu Wg3 Nest with Five Eggs (pulled down 6 or 7 feet). Cardiff. (June 1908)

Bailey

While this bird is a permanent resident, it delays nest building until June and sometimes as late as July or August.

Nu Wg5 Adult Feeding Raspberries to Five Young Birds Posed on Branch; with Inset of Same Bird Feeding Young with Insects. Ithaca. (July 12, 1906)

Bailey

These birds pose readily when placed before the camera. Notice how free they are from fear. While in this position the parent birds brought them food. The waxwing is sometimes destructive to cherries and other fruit, but makes up for this in other ways.

Nu Wg6 Two Adults in Mountain Ash. Ithaca. (April 19) Allen

They often remain about one tree until all the berries are consumed. Plant mountain ash trees to attract them.

Nu Wg8 Adult on Ground “Freezing." Ithaca. (June 19, 1918) Allen

This bird here illustrates mimicry through simulation of form as well as through color. It assumed this pose to escape detection.

\section{Woodcock (Philohela minor)}

The woodcock is another game bird that is likely soon to be exterminated. It is not prolific and is easily shot. To save these birds speedy protection is needed. The woodcock is an excellent example of protective coloration.

ô 10-11; ㅇ 11-12

Nu Wo Adult Incubating Seen from Above and Directly Back, Nest on Ground. (April 30, 1915)

Bailey

This bird still breeds sparingly in the State. Note that the bird can see behind her. Of what advantage is this? The color pattern simulates that of its surroundings.

Nu Wo2 Nest with Four Eggs on Ground. (April 29, 1915) Bailey

The woodcock begins to breed early in April; the eggs are sometimes buried by snow. 
Call no.

\section{Woodcock (continued)}

Nu Wo4 Three Birds Nine Days Old. Cayuga co.

Tabor

Nu Wo6 Adult on Nest. (1900)

A good example of protective coloration. Note the long probelike bill, characteristic of all sandpipers.

\section{Woodpecker, Downy (Dryobates pubescens medianus)}

The most confiding and beneficial of woodpeckers; also the smallest and commonest. It destroys a great number of coddling moths, wood borers and other harmful insects and is, accordingly, of great value in the preservation of forests. From the fact that it is a bird of the orchards and yards, it is accorded the fullest protection and frequently fed by those housewives who appreciate its confiding nature.

Nu WpD Adult Female Feeding on Suet on Side of Tree. (1911)

Bailey

The female is colored like the male except that it does not have the reddish patch back of the head. Note the white stripe on the side of the head just above the line of the eye. Study the structure of the bird and note its adaptability for its work. Observe shape of bill, arrangement of toes and use of tail.

Nu WpD2 Nest with Six Eggs. (1906)

Bailey

The limb holding eggs was removed and a piece of wood cut out. After this picture was made the piece of wood was replaced and the limb strapped in its old place. A second brood was raised a month later in the same nest. The height of the nesting hole may vary from 8 to 50 feet. No nest is built.

Nu WpD4 Two Young Birds on Tree Trunk. .(1908)

Bailey

These birds were removed from the nest and placed against the tree. Notice the black bars on the outer tail feathers. The hairy woodpecker does not have these.

Nu WpD5 Adult at Nest with Food, Young Bird Projecting Head from Nest Hole

Allen

Is it a male or female? What are the young fed? 
Call no.

Woodpecker, Downy (continued)

Nu WpD7 Adult Destroying Bark Beetles. Ithaca. (April 18, 1917) Allen

The bird has destroyed the branch, but in doing so has kept many beetles from spreading. Note time of year.

$\mathrm{Nu}$ WpD8 Adult at Suet Tied to a Branch of a Tree. Ithaca. (February 1910) Allen

Shows the simplest way of attracting birds and the way always to begin by fastening suet to convenient branches, preferably in trees that birds are known to frequent.

\section{Woodpecker, Hairy (Dryobates villosus villosus)}

The hairy woodpecker is somewhat larger than the downy and is confined more closely to the woods. However, it comes even to the windows of dwellings for food that is put out for it.

Nu WpH Adult Eating Suet on Window Casing. Photographed through the window. Ithaca. (December 1913) Allen

Note how the tail is used to support the bird and that the outer feathers have no spots.

Nu WpH1 Adult Female Feeding on Suet on Tree Trunk. (1914)

Bailey

The female does not show red on the head; its coloring is neutral and inconspicuous. Note the "drawn up" position of bird. Characteristic on cold days.

Nu WpH4 Three Young Birds Clinging to a Post. (1913) Bailey

How do they differ from the young downies?

Nu WpH6 Adult on Horizontal Feeding Station, Propped Position Van Zant

The bird is walking on a horizontal surface, but it has become so accustomed to using its tail for a prop that it used it in this case when it is not necessary. 
Woodpecker, Red-bellied (Centurus carolinus)

Now rare in eastern New York, though it was formerly common there. It is uncommon and local in western New York. This species is pursued and its nests destroyed by the red-headed woodpecker.

9.3-10.5

Call no.

Nu WpR Adult Eating Suet from Tree-Trunk. Geneseo. (February 1914)

Bailey

\section{Woodpecker, Red-headed (Melanerpes erythrocephalus)}

In the western part of the State the red-head is probably the most numerous of the woodpeckers. In the eastern part it is not so common. It is primarily a summer resident, but sometimes remains through the winter storing and guarding its food. It frequents slashings and burnt over tracts and may be seen on dead stubs and trees, fence posts and telegraph poles.

$9.3-10$

$\mathrm{Nu}$ WpS Adult Looking into Nesting Hole in Dead Tree Trunk. Arcade. (1906)

R. H. Beebe

This may be either a male or female, as both are alike.

Nu WpS1 Adu1t on Tree Trunk, Feeding on Suet. (February 21, 1914)

Bailey

Note the chisellike bill, characteristic of all woodpeckers.

$\mathrm{Nu}$ WpS4 Two Young Birds Clinging to Tree Trunk, Side View. Arcade. (1904)

R. H. Beebe

How do the young birds differ from the adults?

Nu WpS5 Four Young Birds Clinging to Tree Trunk, Back View. (July 1913)

Bailey

The young birds are able to cling to a vertical tree trunk before they are able to fly, and the stronger ones climb up to the nest opening and receive food from the parent. Note how the toes are arranged to hold onto the bark and how the tail is used as a brace. 


\section{Wren, House (Troglodytes aëdon aëdon)}

The name suggests its common haunts. While generally distributed throughout the State, it is somewhat irregular in its summer visits. This small bird seems quite capable of taking care of itself. It is reported to have the habit of entering nests of bluebirds, yellow warblers, chipping sparrows and other birds and pecking the eggs. This is probably to avoid too much competition for food.

$4.5-5.2$

Call no.

$\mathrm{Nu}$ WrH Adult Entering Hole of Nesting Box

Hegner

The house wren formerly built its nests in deserted woodpecker holes and natural cavities in trees. A large number of them now use boxes put out for their use. The picture shows that it need not be an artistic box, although the more shapely boxes are more attractive to the bird.

$\mathrm{Nu}$ WrH2 Nest Containing Six Eggs in Box, Side Removed. (May 28, 1914)

Allen

Note the composition of the nest.

Nu WrH4 Two Young Birds on Perch. (1909)

Bailey

Compare the appearance of the head and the bill with those of the adult. These birds, when they first leave the nest, skulk and hide in the underbrush and even well-meaning cats are deceived into believing they are mice. Cats are probably doing more to reduce their numbers than is any other cause.

Nu WrH6 Adult Female on Old Stump, Side View. Ithaca. (May 25, 1914)

Allen

Note the position of the tail. When scolding an intruder, the bird's tail is commonly cocked over the back. Notice the character of the bill.

Nu WrH7 Adult Singing on Old Stump, Side View. Ithaca. (May 25,1914 )

Allen

Observe the position of the tail while the bird is singing.

Nu WrH8 Adult with Worm in Its Mouth at Entrance of Nesting Hole. Arcade. (190-) R. H. Beebe

This shows the natural nesting place of the house wren in an old woodpecker hole. 


\section{Wren, House (continued)}

Call no.

Nu WrH9 Adult at Entrance to Nesting Box on Porch. Ithaca. (May 9, 1914) Allen

The box is homemade but properly built.

See also bird box occupied by house wren, Nu ZB3, p. 154.

Wren, Long-billed Marsh (Telmatodytes palustris palustris)

A common summer resident of New York in the vicinity of swamps, larger lakes, the Hudson and Niagara rivers.

Nu WrL2 Nest Attached to Reeds Showing General Form of Nest and Entrance on Side

This bird nests among the reeds and cat-tails. Several nests are usually built in a group and only one of them used.

Nu WrL3 Characteristic Marshy Nesting Site, Nest on Reeds in Foreground. Montezuma. (June 21, 1914) Allen

Long-billed marsh wrens build more nests than they occupy for breeding and one may examine six or eight before finding one with eggs. This is one of the duplicate nests.

Nu WrL4 Longitudinal Section of Nest Showing Ledge of Cat-tail Down at Entrance. Renwick, neas Ithaca. (June 1910)

Allen

This nest was used while the two above were not.

Nu WrL6 Adult Entering Hole of Nest

Notice the material and form of the nest. Compare with that of the ovenbird.

Nu WrL7 Adult at Nest, Side View; Sagitarria. Ithaca. (1908)

Bailey

Nu WrL9 Bumblebee's Nest in Nest of Marsh Wren. Renwick, near Ithaca Allen

The bumblebee ordinarily utilizes nests of the meadow mouse but apparently finds that of the marsh wren also quite to its liking. This nest has been cut in half. 


\section{Wren, Short-billed Marsh (Cistothorus stellaris)}

Not common in this State except in a few localities in the lower Hudson valley and in parts of central and western New York. It is found in dryer, more sedgy marshes than the longbilled.

Call no.

Nu WrS Adult at Nest, View of Back. Canoga, near Cayuga lake. (June 25, 1914)

Allen

How may the short-billed be distinguished from the long-billed marsh wren?

Nu WrS1 Adult on Cat-tail, Side View. Canoga, near Cayuga lake. (June 25, 1914) Allen

Having in mind the size of the cat-tail, what do you judge as to the size of the bird?

\section{Yellowlegs (Totanus flavipes)}

A common migrant shore bird in the fall. It never breeds in New York. It frequents bars, mud flats and marshes particularly when they are left bare by lowering of the water.

9.5-11.5

$\mathrm{Nu} Y$ Adult at Water's Edge. Head of Cayuga lake. (August 26, 1912)

Allen

Note use of long legs and long bill.

Nu Yd8 Four Birds in Flight over Snipe Decoys Planted in Shallow Water. Mastic, L. I. (September 11, 1915)

Harper

The birds with set wings and dangling legs are preparing to alight upon the water. The photographer is in a blind on the shore.

\section{Yellowlegs, Greater (Totanus melanoleucus)}

A common migrant in New York. It frequents sandy beaches, muddy banks and flooded marshes. When approached, it takes flight and by its cry of alarm gives warning of the approach of the hunter. It differs from the yellowlegs only in size. 12.5-15

Nu YdG Adult Standing in Water near Shore. Branchport. (O.ctober 13, 1912)

Burtch

This bird showed no timidity and kept quite close to the photographer for a long time. Usually, however, this species is wild and suspicious. 
Yellowthroat, Maryland (Geothlypis trichas trichas)

Found in all parts of the State as a summer resident. It prefers a swampy or moist locality; sometimes associated with marsh wrens and swamp sparrows.

call no.

Nu YeM1 Adult Male over Nest. (June 9, 1915)

Allen

$\mathrm{Nu}$ YeM2 Adult Female Entering Nest. (June 9, 1915) Allen

The nest is deep and the bird is letting herself down carefully upon the eggs.

$\mathrm{Nu}$ YeM4 Adult Incubating. (June 9, 1915)

Allen

The nest was in the sedges bordering a marsh.

Nu YeM55 Overturned Nest. Potters swamp, Branchport. (June 1, 1913)

Burtch

\section{GENERAL TOPICAL STUDIES}

As the study of individual species of birds progresses one should note relations and begin to form in mind significant groupings of whatever has been observed.

The following topics are offered as suggestions. The call numbers are those of pictures that seem to be good illustrations of the topics named. Only a limited number of the most typical species have been chosen to illustrate each point. Other birds might as well have been used and teachers should encourage the application of the principles involved to all birds and draw from pupils the names of other species that illustrate each phase of the subject. Thus when discussing color and sex, the pupils should be asked to make a list of all the birds in which the males and females are different. And in a study of protective coloration, lists of birds that have banner marks, ruptive marks or obvious counter shading should be made and the color patterns should be studied from the point of view of the bird's environment to determine if there is any correlation.

\section{Mating and Nesting}

1 Courtship: accomplished by song and display of plumage

With the arrival of the females, courtship commences immediately, though a few species seem to be mated when they arrive 
on the nesting grounds. Some birds do not sing until after the arrival of the females, but with most species the males are singing when the females arrive. By song and display of plumage, the males try to entice the females to settle in the chosen area and fierce combats often ensue between rival males.

$a$ Song

Swamp sparrow singing

$b$ Display

White-breasted nuthatch
$\mathrm{Nu} \quad \mathrm{SpS}$

$\mathrm{Nu} \quad \mathrm{NuW9}$

The photograph shows the nuthatch in display to frighten the sparrow. Similar display is used during courtship to help win the female and drive away other males.

2 Time of nest building

In New York State this varies with different species from February to September. The male birds ordinarily precede the females in the migration and arrive on the nesting ground from a few days to a few weeks earlier. They select the general area in which there seems to be plenty of food and shelter and where they wish to locate for the summer and then proceed to drive off other males from this area, awaiting the arrival of the females. Old birds ordinarily return to the same place where they nested the year before, but the young of the preceding year have to find suitable places that are not already occupied.

a Early nests

Prairie horned lark, eggs in snow

Prairie horned lark, young in snow

Great horned owl (March)

$b$ Late

Goldfinch (September)
$\mathrm{Nu} \mathrm{LdP3}$

$\mathrm{Nu}$ LdP4

$\mathrm{Nu} \quad \mathrm{OwG} 2$

$\mathrm{Nu}$ Go3

3 Selection of the nesting site and nest

a For protection

The female ordinarily selects the nesting site and does most of the nest building, while the male accompanies her and stands guard ready to drive off all competitors. The choice of the nesting site is influenced by several factors but chiefly by the need for protection both from bird enemies and from the elements. 
A bird's enemies are numerous, but the methods of nest concealment are just as numerous. The commonest method is the selection of a site which will be concealed from all points of view by surrounding grasses or leaves. In photographing a nest it is usually necessary to move the leaves from above or in front of the nest, hence a picture of it does not show the normal condition of concealment. Other methods of concealment or protection employed by various species are the building of roofs over the nest either by using nesting material (meadowlark) or by pulling the grasses together over the nest (sora), and the building of the nest in accessible places.

(1) Concealed

$\begin{array}{lll}\text { Ficld sparrow } & \mathrm{Nu} & \mathrm{SpF} 2 \\ \text { Ovenbird } & \mathrm{Nu} & \mathrm{Ov2} \\ \text { Indigo bunting } & \mathrm{Nu} & \mathrm{BuI} 2 \\ \text { Least flycatcher } & \mathrm{Nu} & \mathrm{FnL} 2 \\ \text { Meadowlark } & \mathrm{Nu} & \mathrm{Mf2} \\ \text { Slate-colored junco } & \mathrm{Nu} & \mathrm{JuS6} \\ \text { Sora } & \mathrm{Nu} & \mathrm{So3} \\ \text { Pied-billed grebe } & \mathrm{Nu} & \mathrm{GsP2}\end{array}$

How is each concealed?

(2) Inaccessible

$\begin{array}{lll}\text { Duck hawk, on ledge } & \mathrm{Nu} & \mathrm{HD} 2 \\ \text { Black-crowned night heron, in tree top } & \mathrm{Nu} & \mathrm{HeB} 2 \\ \text { Oriole, on tip of branch } & \mathrm{Nu} & \mathrm{OrB} \\ \text { Osprey, normal site, in tall tree } & \mathrm{Nu} \text { Os4 } \\ \text { Osprey, on Gardiners island } & \mathrm{Nu} \text { Os8 }\end{array}$

There being no terrestrial enemies such as cats, skunks, coons, weasels, minks and depredating men on Gardiners island, the osprey returns to nesting on the ground.

\section{$b$ Attachment to}

A bird becomes greatly attached to its nesting site and in many cases an individual returns to the same bush or tree year after year. If the old nest is still substantial, it is repaired; but as a rule a new nest is built in the vicinity of the old.

Eagle, nest several years old
Phoebe, two nests side by side
Oriole, two nests close together
$\mathrm{Nu}$ EB

$\mathrm{Nu}$ Pk32

$\mathrm{Nu}$ OrB3 
$c$ Relation to haunts and habits

Most birds nest where they search for their food, but there are exceptions to this rule.

Bobolink, a bird of the fields

$\mathrm{Nu} \quad \mathrm{Bo} 2$

Ovenbird, a terrestrial bird of the woods

$\mathrm{Nu} \quad \mathrm{Ov} 3$

Downy woodpecker

Downy woodpecker and nest

$\mathrm{Nu}$ WpD7

$\mathrm{Nu} \quad \mathrm{WpD} 5$

Woodpeckers search for their food by drilling in trunks of trees, where they nest.

Brown creeper, seeking food in crevices of $\mathrm{Nu} \mathrm{CsB}$ bark

Brown creeper, nest under bark of tree $\quad \mathrm{Nu}$ CsB2

Aerial birds show great variety as to nesting sites.

Bank swallow

$\mathrm{Nu} \quad \mathrm{SuB} 2$

Barn swallow

$\mathrm{Nu} \mathrm{SuC4}$

Tree swallow

$\mathrm{Nu} \mathrm{SuT} 2$

$d$ Change of site due to change of conditions

Some birds are much more adaptable than others and with the change in natural conditions have been able to take advantage of new conditions as indicated by the various birds that nest about the habitations of man.

Cliff swallow, natural site

$\mathrm{Nu} \quad \mathrm{SuE} 2$

Cliff swallow, adapted site

$\mathrm{Nu} \quad \mathrm{SuE3}$

Phoebe, natural site

$\mathrm{Nu} \quad \mathrm{Pk} 3$

Phoebe, adapted site

$\mathrm{Nu} \quad \mathrm{Pk} 4$

4 Nest building

$a$ Gathering material

Yellow warbler with cotton

Oriole gathering strings

$\mathrm{Nu} \quad \mathrm{WY} 3$

Tree swallow with feather

$\mathrm{Nu} \quad \mathrm{OrB2}$

$\mathrm{Nu} \quad \mathrm{SuT3}$

$b$ The start of the nest

Red-winged blackbird

$\mathrm{Nu} \quad \mathrm{B} 124$

$c$ For ornamentation as a means of concealment

The "ornamentation of nests," the employment of ribbons and paper by thrushes and vireos, and of lichens by pewees and hummingbirds, is entirely for protection, to make the nest look like something else. 
Hummingbird

Wood pewee

Wood thrush

Redstart
$\mathrm{Nu} \quad \mathrm{HuR} 3$

Nu Pi2

$\mathrm{Nu}$ TiW5

$\mathrm{Nu}$ Rf1

\section{$d$ The inexperienced builder}

The instinct to build the type of nest characteristic of the species is inherited, but birds learn through experience to build stronger and better protected nests. The first nests built by immature birds are often quite poorly constructed and placed.

Red-winged blackbird

$\mathrm{Nu} \quad \mathrm{B} 13$

\section{$e$ Duplicate nests}

Long-billed marsh wren, nest in use $\mathrm{Nu}$ WrL4

Long-billed marsh wren, duplicate nest $\mathrm{Nu}$ WrL2

In the wren family, the males are assiduous nest builders and often build several nests before the arrival of the females and continue thereafter building duplicate nests, which are not used for anything unless it be for roosting. These duplicate nests are usually much more conspicuous than the one in which the eggs are laid. Note the conspicuousness of this duplicate nest.

\section{$f$ Nest repairing}

Red-eyed vireo

$\mathrm{Nu}$ ViR

$g$ Relation of haunt of bird to nest material

The materials which birds use in nest building are determined largely by the haunt of the bird. The materials that are most available are always used provided they are suited to the general type of nest characteristic of the species. Birds that live in the fields ordinarily use grasses and horsehair. Those that live in the woods use rootlets and dead leaves, etc. Birds that spend most of their time on the wing and meet with no particular set of materials vary the most in their nest construction.

Field sparrow, grass nest of field bird

Blackburnian warbler, rootlet nest of woodland bird

$\mathrm{Nu} \quad \mathrm{SpF} 3$

Florida gallinule, reed nest of marsh bird

Nu WA3

$\mathrm{Nu} \quad \mathrm{GcF}$

\section{Types of nests-evolution}

One of the most interesting phases of nest building is its evolution from the most simple to the most complex form and construction. One can trace in the nests built by birds today what has been the probable evolution of the most complicated nests 
that we see. It is believed that elaborate nests like those of the oriole have been gradually erolved from the simpler types. The earliest birds, like their reptilian ancestors, probably did not build nests but like turtles and like the mound birds of Australia today buried their eggs in the sand or in heaps of decaying vegetation. With the great change from a cold-blooded to a warmblooded condition of birds came the need for maintaining the eggs at a constant temperature and incubation started. The eggs were then laid on the surface of the ground or in holes in trees where the bird could cover them. Those birds that laid their eggs on the ground found it more comfortable and safe to lay them in a depression and then to line the depression with grasses or leaves. But the eggs were subject to the wet and cold and some species then evolved nests that were built up from the ground on piles of leaves, etc. The next step was the building of the nest in a bush or tree. Some species learned how by laying twigs in the forks of trees they could build crude platforms that would hold their eggs and keep them above the flood and their terrestrial enemies. Gradually the instinct to build more and more complicated nests in the branches of trees arose until finally we have such elaborate nests as those of the oriole suspended from the tip of a branch or ornamented nests like those of the hummingbird and pewee. Trace this probable evolution in the series of pictures selected to illustrate this topic.

Nighthawk, no nest

Killdeer, simple depression

Spotted sandpiper, some lining

Vesper sparrow, nest well lined

Virginia rail, nest built up from ground

Black-crowned night heron, crude nest in tree

Black-billed cuckoo, crude nest with slight lining

Catbird, well formed nest of sticks with considerable lining

Song sparrow, nest of finer materials, well formed, deep with soft lining

Wood thrush, nest with middle layer of plastered mud

Barn swallow, fully plastered nest

Goldfinch, entirely made of soft material

Acadian flycatcher, semihanging nest

Baltimore oriole, hanging nest

Yellow-throated vireo, ornamented hanging nest

$\begin{array}{ll}\mathrm{Nu} & \mathrm{Ni2} \\ \mathrm{Nu} & \mathrm{Ke} 3 \\ \mathrm{Nu} & \mathrm{ST} 2 \\ \mathrm{Nu} & \mathrm{SpV} 2 \\ \mathrm{Nu} & \mathrm{RV3} \\ \mathrm{Nu} & \mathrm{HeB} 3 \\ \mathrm{Nu} & \mathrm{CvB} 2 \\ \mathrm{Nu} & \mathrm{Cd} 2 \\ & \\ \mathrm{Nu} & \mathrm{SpR} 2 \\ & \\ \mathrm{Nu} & \mathrm{TiW} 2 \\ \mathrm{Nu} & \mathrm{SuC2} \\ \mathrm{Nu} & \mathrm{Go} 2 \\ \mathrm{Nu} & \mathrm{Fn} 1 \\ \mathrm{Nu} & \mathrm{OrB} \\ & \\ \mathrm{Nu} & \mathrm{ViY3}\end{array}$




\section{Hole nesters}

The birds that elected to lay their eggs in the holes of trees found it unnecessary to build nests and from the beginning have never developed a nest-building instinct other than learning to drill their own cavities. Later on some birds that had developed a nest-building instinct in the open, discovered that their eggs were much safer in the cavities in trees or banks, than in open nests, and took to building their nests in such places. In spite of the fact that nests are unnecessary in such places, they still retain the nest-building instinct and build elaborate nests at the bottom of the cavity.

$a$ The original type, at bottom of hole, no structure
Downy woodpecker
$\mathrm{Nu} \quad \mathrm{WpD}_{2}$

Sparrow hawk

$\mathrm{Nu} \mathrm{HT} 3$

$b$ Reversion to hole nesting, nest at bottom of hole
Bluebird
$\mathrm{Nu} \mathrm{Bm} 3$
Chickadee
$\mathrm{Nu} \quad \mathrm{Ci3}$

7 Degenerate nesters-parasitism

Cowbird's eggs in vireo's nest

$\mathrm{Nu} \quad \mathrm{ViB} 2$

Cowbird's eggs built upon by vireo

Young cowbird hatched by vireo

$\mathrm{Nu} \quad \mathrm{ViB} 3$

Yellow-billed cuckoo egg in black-billed cuckoo nest

$\mathrm{Nu} \quad \mathrm{ViB} 4$

$\mathrm{Nu} \quad \mathrm{CvB} 4$

\section{Eggs}

The eggs of birds are among the most beautiful objects in all nature. It is little wonder that the instinct of the small boy in response to the appeal which they make to his eye leads him to make an egg collection. In presenting the following study effort should be made to interest children in the manner in which the parent birds care for their eggs and in the young which hatch from them and to discourage in every way the making of egg collections. What the egg is in and what is in the egg are more important interests than mere form, color and size of the shell.

\section{Number}

The number of eggs laid by an individual is fairly constant for each species.

a Small

Mourning dove, 2 eggs

Hummingbird, 2 eggs
$\mathrm{Nu} \quad \mathrm{DoM} 2$

$\mathrm{Nu} \quad \mathrm{HuR} 2$ 
$b$ Normal, 4 or 5

Chestnut-sided warbler

Catbird

Nu WE3

$\mathrm{Nu} \mathrm{Cd} 2$

$c$ Large
Grouse, 15 eggs
$\mathrm{Nu} \quad \mathrm{GuR} 3$
Mallard, 9 eggs; 10 eggs
$\mathrm{Nu} \quad \mathrm{Mc} 2$

Game birds lay from eight to twenty eggs.

2 Size

$a$ Actual

The eggs vary in size from those of the hummingbird to those of the ostrich. For eggs of the hummingbird, see Nu HuR2; for those of the ostrich, see $\mathrm{Cv}$ Y3, List 38, p. 10.

$b$ Relative to the bird

Catbird and Spotted Sandpiper; an Egg of

Each. Specimens, New York State Museum. (1919)

$\mathrm{Nu} \quad \mathrm{Cd} 3$

Birds which have precocial young lay relatively larger eggs than those which have altricial young, because the embryos are nourished longer within the egg. Compare the relative size of the eggs and the birds in the catbird and the spotted sandpiper, birds of approximately the same size.

\section{Color}

The nest is most conspicuous when the eggs lie in it uncovered, that is, previous to the beginning of incubation. If the eggs pass though this period safely, they have a good chance of being hatched. Birds building no nest at all usually lay very protectively colored eggs and have protectively colored young but those building bulky, conspicuous nests likewise have conspicuous eggs and rely upon the inaccessibility of the nesting site or upon concealment of the whole structure to protect them.

$a$ Protectively colored

Killdeer

Night hawk

Caspian tern
$\mathrm{Nu} \quad \mathrm{Ke} 3$

$\mathrm{Nu} \quad \mathrm{Ni} 2$

$\mathrm{Nu} \quad \mathrm{TfC} 2$

$b$ Conspicuous eggs

Wood pewee

Black-crowned night heron

$\mathrm{Nu} \quad \mathrm{Pi} 2$

Green heron

$\mathrm{Nu} \mathrm{HeB} 3$

$\mathrm{Nu} \mathrm{HeH} 2$ 


\section{$c$ Color of eggs of hole nesters}

Birds that have always nested in holes, like the woodpecker, whose eggs are out of sight and have never needed protective coloration, lay pure white eggs. Birds that have reverted to a hole nesting habit, as shown by the fact that they still build unnecessary nests at the bottom of the cavities, still lay colored eggs. In some, like the bluebird, however, it seems as though the eggs were in the process of fading.

(1) Without nests-original type

Downy woodpecker

$\mathrm{Nu} \quad \mathrm{WpD}_{\mathrm{p}} 2$

(2) With nest-reversion type

Crested flycatcher

$\mathrm{Nu} \quad \mathrm{FnC2}$

Bluebird

$\mathrm{Nu} \quad \mathrm{Bm} 3$

Compare eggs of bluebird with those of other thrushes.

$d$ Coloring typical for each family

The color of the eggs is remarkably constant for each species and is remarkably uniform for all the species of each family, although some species show marked variation. The eggs of species of different families, however, vary from pure white to almost pure black.

Thrushes-blue eggs

Robin

$\mathrm{Nu} \quad \mathrm{Ro} 2$

Veery

$\mathrm{Nu} \mathrm{Ve} 2$

Wood thrush

$\mathrm{Nu}$ TiW2

Owls-pure white

Barn

Barred

Great horned

Long-eared

$\mathrm{Nu}$ OwB3

$\mathrm{Nu}$ OwC2

$\mathrm{Nu}$ OwG3

$\mathrm{Nu}$ OwL2

Rails-tan spotted

Clapper rail

Coot

Gallinule

$\mathrm{Nu}$ RD2

$\mathrm{Nu} \mathrm{Cn} 2$

$\mathrm{Nu} \quad \mathrm{GcF}$

Sparrows-bluish or grayish white spotted with brown

Field

Song

Chipping

Vesper

White-throated

$\mathrm{Nu} \mathrm{SpF} 2$

Nu SpR2

$\mathrm{Nu} \quad \mathrm{SpC} 2$

$\mathrm{Nu} \mathrm{SpV} 2$

$\mathrm{Nu} \quad \mathrm{SpX} 2$ 
$e$ Variation in color and markings in species

Song sparrow, eggs showing maximum variation

$\mathrm{Nu} \quad \mathrm{SpR3}$

Swamp sparrow, normal eggs

$\mathrm{Nu} \quad \mathrm{SpS} 2$

Swamp sparrow, abnormal eggs

$\mathrm{Nu} \quad \mathrm{SpS} 3$

4 Shape

The usual shape of eggs is ovoid, but owls lay eggs that are nearly spherical and sandpipers very pointed ones.

$a$ Normal-ovoid

Rose-breasted grosbeak

$\mathrm{Nu} \quad$ GtR2

$b$ Pointed

Upland plover

$\mathrm{Nu} \quad \mathrm{PpU} 2$

Spotted sandpiper

$\mathrm{Nu} \quad \mathrm{ST} 24$

In what sort of nests are such pointed eggs found? What is the special advantage of this shape?

c Spherical

Great horned owl

$\mathrm{Nu} \quad \mathrm{OwG} 2$

\section{Incubation}

The purpose of incubation is to maintain the eggs at a uniform temperature approximately that of the body of the brooding bird.

Birds ordinarily lay one egg each day and do not begin to incubate until the normal complement is complete so that the eggs will all hatch at approximately the same time and the young have an equal chance to grow. The owls, the bitterns and the cuckoos, however, sometimes lay eggs at irregular intervals and begin incubating before the complement is complete. The eggs do not hatch at the same time and the young in a nest may be of various sizes.

$a$ Begins when

(1) Usual-with the laying of the last egg so that eggs hatch together and young all same size Chickadees

$\mathrm{Nu} \quad \mathrm{Ci} 4$

(2) Unusual-with the laying of first egg before complement is complete

Black-billed cuckoo, young and eggs in same nest

$\mathrm{Nu}{ }^{-} \mathrm{C}$ B 5

Bittern, young of very different sizes

Screech owl, young, several days difference in age

$\mathrm{N}$ BiA6

$\mathrm{Nu} \quad$ OwS24 


\section{$b$ Brood spot}

In order to bring the eggs in direct contact with the body the middle of the breast does not bear feathers and is covered by the overlapping of those on each side. When the bird settles upon her eggs, these feathers are spread and the bare skin of this area which, during the nesting season is richly supplied with blood and is called a "brood spot," is brought in direct contact with the eggs.

Killdeer

$\mathrm{Nu} \mathrm{Ke} 2$

\section{$c$ Sex performing}

When the sexes are alike in color, both ordinarily take turns in incubation but when the male is brighter, most of the duties fall to the female, the male either feeding her while she incubates or standing guard by the nest while she hunts her own food. There are a few exceptions to this, the male rose-breasted grosbeak, for example, being quite assiduous in his assistance at incubation.

(1) Female only

Goldfinch

(2) Male and female in turn

Least bittern, male incubating

Chestnut-sided warbler

Marsh hawk, male at nest

(3) Male attending female

Common tern, male standing by

Chipping sparrow
Nu Go2

$\mathrm{Nu} \quad \mathrm{BiL}$

$\mathrm{Nu}$ WE1

$\mathrm{Nu} \mathrm{HM}$

$\mathrm{Nu}$ TfD2

$\mathrm{Nu} \quad \mathrm{SpC} 3$

\section{$d$ Care of eggs}

(1) Turning

The eggs are regularly turned by the old bird and occasionally moistened.

Florida gallinule

$\mathrm{Nu} \quad \mathrm{GcF} 3$

\section{(2) Defending}

As incubation progresses the instinct to defend the nest increases until when the eggs are about to hatch, some individuals seem not to know fear and refuse to leave the nest even when touched or they may even attack the aggressor. 
(a) Lack of fear

Blackburnian warbler

Ring-necked pheasant

(b) Active defense

Least' bittern
$\mathrm{Nu}$ WA8

$\mathrm{Nu} \quad \mathrm{Pj}$ R6

$\mathrm{Nu} \quad \mathrm{BiL} 24$

\section{Hatching}

On the tip of the upper mandible of the young birds in the shell a small pointed tooth develops which by the twisting of the young bird cuts through the shell and permits the youngster to escape. Ordinarily no help is needed from the old bird but occasionally she gets impatient, especially in the presence of danger, and assists the young one to break the egg. With some species the eggs are always broken in two pieces with very even edges - a cap being cut off from the larger end. As soon as the young have hatched the egg shells are removed or eaten by the old bird. If an egg proves infertile and does not hatch, it may be thrown from the nest or it may be left in the bottom.

a Normal breaking

Virginia rail

Nu RV5

Note that the fourth bird is breaking through the shell. Gallinule $\mathrm{Nu}$ GcF52

$b$ Method in grouse family

Young pheasants

Young grouse

$\mathrm{Nu} \quad \mathrm{PjR} 4$

$\mathrm{Nu}$ GuR5

$c$ Removal of shells and bad eggs

Pied-billed grebe removing shell

$\mathrm{Nu} \quad \mathrm{GsP} 4$

Bobolink egg removed

$\mathrm{Nu} \mathrm{Bo} 4$

\section{The Young}

\section{Condition at hatching}

The young of birds at hatching are of two types, precocial and altricial. The grebes, loons, gulls, terns, ducks, marsh birds, shore birds and fowllike birds have precocial young and other birds have altricial young.

\section{a Precocial}

Their eyes open immediately after hatching and they are clothed in thick down. They are able to run about or swim as 
soon as they have dried off and to follow their parents about. Domestic chickens and ducklings are familiar examples of this type of young.

Grebc
Grouse
Gallinule
Sora
Virginia rail

\section{$b$ Altricial}

Altricial birds are hatched blind and helpless ancl are cared for in the nest by the parents for a considerable period. The amount of covering varies from that of birds absolutely naked, through that of those having a scant coating of down along the principal feather tracts, to that of those well clothed in down. Their eyes open in a few days and their rate of growth is surprising, some ground-nesting species like larks and sparrows having acquired their feathers and being ready to run from the nest in a week. Others, like the hawks and eagles, that must develop large, strong wings before they can leave, remain in the nest for several months.

$\begin{array}{lll}\text { Kingfisher, no down } & \mathrm{Nu} & \mathrm{KiB3} \\ \text { Horned larks, little down } & \mathrm{Nu} & \mathrm{LdP} \\ \text { Red-shouldered hawk, much down } & \mathrm{Nu} & \mathrm{HP4}\end{array}$

2 Care of young

a Feeding

(1) Precocial young

These young follow their parents about while the latter find food for them and teach them to find it for themselves.

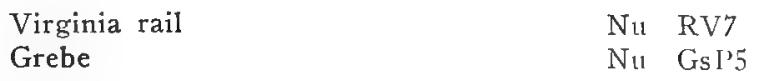

(2) Altricial young

The young of this type are fed by their parents during the time they are in the nest and for a considerable period thereafter.

(a) Normal method
Mourning warbler
Louisiana water-thrush

At first the parent bird places the food far down in the throat of the young. There is a delicate physiological adjustment between the young bird's stomach and the muscles of its throat 
so that as soon as it has received sufficient food the muscles refuse to act. If the old bird does not get the proper reaction, it removes the food from the throat of the young bird and gives it to the next one. As the young bird gets older the food is not placed so far down the throat. The bird is gradually taught to pick up or catch food of its own accord.

(b) Regurgitation

Hummingbird

Waxwing

Nı HuR5

Least bittern

$\mathrm{Nu} \quad \mathrm{Wg} 2$

$\mathrm{Nu}$ BiL5

At first these birds are fed by regurgitation upon partially digested food. In some cases this is soon changed to a dict of insects. Hummingbirds, waxwings, doves and a few others continue to feed by regurgitation during the entire period.

(c) Pelican method

Brown Pelican, Habitat Group, Showing

Large Number of Birds in Various

Attitudes. American Museum of Natural History, New York. (1918) Nu PfB1

Young pelicans put their heads into the pouch of the old bircl for their food.

(d) Hawk method-tearing food apart

Cooper hawk

$\mathrm{Nu} \mathrm{HC} 4$

Young hawks are early taught to pull their prey apart and later to fly up and take it from the talons of the old bird.

(e) Teaching young to feed by themselves

Tree swallows, when young

Trce swallows, when older

$\mathrm{Nu}$ SuT5

$\mathrm{Nu} \quad \mathrm{SuT} 54$

Young swallows are taught to catch flying insects by the old birds flying past them and dropping the insects into their wide open mouths without stopping, and later repeating this operation when the young birds have learned to fly and follow them about.

Duck hawk

Nu HD4 and Nu HD5

$b$ Brooding

Normal-beneath breast and wings

Killdeer
Veery
Robin in rain

$\mathrm{Nu} \quad \mathrm{Ke} 7$

$\mathrm{Nu}$ Ve6

$\mathrm{Nu}$ Ro7 


\section{c Defense of nest and young}

The instinct of the parent to defend the young increases as the latter develop and reaches its highest point as they are leaving the nest. Birds have various ways of responding to the approach of an enemy. Some feign a broken wing, others dart at the enemy, or present a ferocious appearance, while the vast majority merely utter crics of distress which brings out all the other birds of the neighborhood.

(1) Cries of distress

Robin

$\mathrm{Nu} \quad \mathrm{Ro74}$

(2) Darting at enemy

$\begin{array}{lll}\text { Black tern } & \text { Nu } & \text { TfB9 } \\ \text { Bittern } & \text { Nu } & \text { BiA }\end{array}$

(3) Feigning broken wing

Killdeer

$\mathrm{Nu} \mathrm{Kc8}$

\section{$d$ Nest sanitation}

Most birds keep the nest scrupulously clean, the excrement being removed after each feeding. To facilitate this nature incloses it in a mucous sheath so that it can be easily carried. Some birds, however, regularly devour it. Fish-eating birds are rather unclean and the tops of the tree in a heronry are frequently killed by the chalky excrement.

(1) Normal

$\begin{array}{lll}\text { Red-winged blackbird inspecting } & \mathrm{Nu} & \mathrm{B} 15 \\ \text { Red-winged blackbird cleaning } & \mathrm{Nu} & \mathrm{B} 152 \\ \text { Red-winged blackbird with excrement } & \mathrm{Nu} & \mathrm{B} 158 \\ \text { Meadowlark } & \mathrm{Nu} & \mathrm{Mf6}\end{array}$

(2) Unclean

Great blue heron

$\mathrm{Nu} \mathrm{HcF} 2$

3 Growth of feathers

$a$ General method

The feathers of a bird are not borne over the entire surface of the skin but on well-defined lines or tracts with bare spaces between that are covered by the overlapping of the feathers. When the real feathers begin to develop, they are inclosed in stiff, bluish sheaths which make these feather tracts very conspicuous. With most birds these feather sheaths, or "pin 
feathers" as they are rather incorrectly called, push out the down feathers on their growing tips and begin to split open shortly after they appear. The change from the almost naked young to the fully feathered one is usually gradual.

$$
\text { Red-winged blackbirds; four stages } \quad \mathrm{Nu} B 138
$$

\section{$b$ Method of growth in cuckoos and kingfishers}

With the cuckoo, kingfisher, hummingbird and swift, however, the quills do not split open until the feathers are nearly full grown inside. For a time the young birds are covered with curious coats of mail and the change from this stage to the fully feathered condition may take place in a few hours.

\section{Kingfishers in quills \\ Kingfishers in feathers \\ Yellow-billed cuckoo}

$\begin{array}{ll}\mathrm{Nu} & \mathrm{KiB} 4 \\ \mathrm{Nu} & \mathrm{KiB5} \\ \mathrm{Nu} & \mathrm{CrY6}\end{array}$

\section{Development of fear instinct}

At first the young of birds seem not to know fear and raise their wobbly heads for food at any disturbance about the nest. As soon as they have strength to respond to the calls of their parents, however, the fear instinct develops. The old bird gives a feeding call when it approaches the nest. Unless the young hear this, any disturbance about the nest causes them to crouch and try to hide. A study of the different calls of the old birds and the responses of the young is very interesting.

$a$ In precocial young, at hatching-"play possum"

Killdeer

$\mathrm{Nu}$ Ke5

$b$ In altricial young, when they develop feathers

$\begin{array}{lll}\begin{array}{l}\text { Young crows at hatching, no fear } \\ \text { Young crows feathered, crouching, fear de- }\end{array} & \mathrm{Nu} & \mathrm{Cu} 4 \\ \begin{array}{l}\text { veloped } \\ \text { Owl, unfrightened }\end{array} & \mathrm{Nu} & \mathrm{Cu} 46 \\ \text { Owls, frightened } & \mathrm{Nu} \text { OwL4 } \\ \text { Herons, unfrightened } & \mathrm{Nu} \text { OwL5 } \\ \text { Herons, frightened } & \mathrm{Nu} \mathrm{HeH} 4 \\ & \mathrm{Nu} & \mathrm{HeH} 5\end{array}$

5 Appearance of fully fledged young

See illustrations and notes under coloration, p. 148. 


\section{The Distribution of Nesting Birds}

\section{Life zones or range}

All of North America has been divided into transcontinental bands, or zones, according to differences in temperature and corresponding differences in plant and animal life. These bands, called life zones, are bounded by definite isotherms. They are naturally very irregular in contour because the mean temperature of every locality is affected by so many different things, such as altitude, presence of large bodies of water, etc.

In New York State there are three well-defined zones (Birds of N. Y., p. 19-42), the Canadian or coolest, the austral or warmest, and the transition or intermediate. The main portion of the State is in the transition zone and the majority of birds are typically transition species. The Canadian zone is found throughout the Adirondacks and Catskill region and on hill tops and in cool swamps in other parts of the State. The austral zone predominates in the lower Hudson valley and along the south shore of Lake Ontario where the temperature is modified by the lake. One can tell in which life zone his locality lies by the presence or absence of certain nesting birds. Thus where whitethroated sparrows, juncos, hermit thrushes and myrtle warblers nest, one can feel sure he is in the Canadian zone. Where cardinals, tufted titmice, Kentucky warblers and yellow-breasted chats are found, it is the austral zone. Where the robin, wood thrush, yellow warbler and rose-breasted grosbeak are common nesters, it is the transition zone. On the tops of the highest Adirondacks and Catskills there is a tinge of a fourth, the Hudsonian zone, where blackpoll warblers, Bicknell's thrushes and three-toed woodpeckers are found.

The distribution of birds within each zone is not always uniform, for some species are remarkably erratic or local in their distribution. Thus while the blue jays and brown thrashers are common in eastern and western New York, they are rare in central New York.

\section{Habitat or environment}

The study of birds is greatly facilitated when one knows just where to expect to find each species. Every species is adapted for some particular habitat and though on its migrations it may be found at a considerable distance from its favorite haunt, when nesting begins and a bird's movements are more restricted, the 
majority of birds do not go far from their chosen retreats. Some, like the robin and crow and song sparrow, adaptable species, are found in a great many different places. The majority of species are restricted to one of the following six environments: $a$ fields, $b$ shrubbery, in gardens and woodland borders, $c$ woodlands, $d$ orchards and shade trees, $e$ buildings, $f$ marshes. Group $e$, of course, consists of adaptable species that have left their former haunts to associate with man. They will likewise be found in some of the other habitats.

\section{$a$ Birds of the fields}

These birds are typical of the open fields away from bushes or trees of any kind. They are usually flushed from the ground or seen perched on fence posts or other points of vantage about the fields. They always nest on the ground and many of them sing on the wing.

(1) Nesting in open fields

$\begin{array}{lll}\text { Meadowlark } & \mathrm{Nu} & \mathrm{M} 1 \\ \text { Vesper sparrow } & \mathrm{Nu} & \mathrm{SpV} 3 \\ \text { Savanna sparrow } & \mathrm{Nu} & \mathrm{SpP3} \\ \text { Henslow sparrow } & \mathrm{Nu} & \mathrm{SpJ} 3 \\ \text { Bobolink } & \mathrm{Nu} & \mathrm{Bo} \\ \text { Pheasant } & \mathrm{Nu} & \mathrm{PjR} \\ \text { Killdeer, usually near water } & \mathrm{Nu} & \mathrm{Ke} \\ \text { Spotted sandpiper, usually near water } & \mathrm{Nu} & \mathrm{ST} 2 \\ \text { Snow bunting, found only in winter } & \mathrm{Nu} & \mathrm{BuS6}\end{array}$

(2) Nesting in cuts and embankments

$\begin{array}{lll}\text { Bank swallow, nesting site } & \mathrm{Nu} & \mathrm{SuB} 3 \\ \text { Bank swallow } & \mathrm{Nu} & \text { SuB6 } \\ \text { Kingfisher } & \mathrm{Nu} & \text { KiB6 }\end{array}$

$b$ Birds of the shrubbery; woodland borders and gardens

These birds are found wherever there is a growth of bushes for nesting. They are occasionally found in the open fields or in woodlands but never far from bushes.

Catbird

Brown thrasher

Song sparrow

Field sparrow

Black-billed cuckoo

Yellow-breasted chat

Indigo bird

Chestnut-sided warbler
$\begin{array}{ll}\mathrm{Nu} & \mathrm{Cd} 4 \\ \mathrm{Nu} & \mathrm{ThB2} \\ \mathrm{Nu} & \mathrm{SpR} 2 \\ \mathrm{Nu} & \mathrm{SpF} 1 \\ \mathrm{Nu} & \mathrm{CvB3} \\ \mathrm{Nu} & \mathrm{ChY4} \\ \mathrm{Nu} & \mathrm{BuI} 2 \\ \mathrm{Nu} & \mathrm{WE} 1\end{array}$ 
$c$ Birds of the woodlands

Woodland birds are rather a diverse group. Some regularly live and nest on the forest floor, others in the undergrowth or on the lower branches of the trees, some in holes, usually in dead trees, and others in the tree tops. Many of the orchard and shade tree birds are likewise found in the woodlands, but these have purposely been omitted from the present list.

(1) Terrestrial birds

$\begin{array}{lll}\text { Ruffed grouse } & \mathrm{Nu} & \text { GuR2 } \\ \text { Ovenbird } & \mathrm{Nu} & \text { Ov2 } \\ \text { Water-thrush } & \mathrm{Nu} & \text { Wf2 } \\ \text { Towhee } & \mathrm{Nu} & \text { Tp5 } \\ \text { Veery } & \mathrm{Nu} & \text { Ve4 }\end{array}$

(2) Birds of the undergrowth and low branches

Black-throated blue warbler

$\mathrm{Nu}$ WB2

Red-eyed vireo

$\mathrm{Nu}$ ViR

Rose-breasted grosbeak

$\mathrm{Nu} \quad \mathrm{GtR}$

Redstart

Acadian flycatcher

$\mathrm{Nu}$ Rf1

$\mathrm{Nu}$ Fn1

(3) Hole nesters

Downy woodpecker

Screech owl

Red-headed woodpecker

Sparrow hawk

Chickadee

White-breasted nuthatch

$\mathrm{Nu}$ WpD5

$\mathrm{Nu}$ OwS

$\mathrm{Nu}$ WpS

$\mathrm{Nu}$ HT3

$\mathrm{Nu} \quad \mathrm{Ci} 2$

$\mathrm{Nu} \mathrm{NuW} 2$

(4) Birds of the tree tops
Crow
$\mathrm{Nu} \mathrm{Cu} 5$
Cooper hawk
$\mathrm{Nu} \mathrm{HC} 4$
Black-crowned night heron
$\mathrm{Nu} \mathrm{HeB}$
A heronry
Cerulean warbler
Blackburnian warbler
$\mathrm{Nu} \mathrm{HeBl}$
Nu WD1
$\mathrm{Nu}$ WA8

$d$ Birds of the orchards and shade trees

$\begin{array}{lll}\text { Baltimore oriole } & \mathrm{Nu} \text { OrB } \\ \text { Goldfinch } & \mathrm{Nu} \text { Go7 } \\ \text { Least flycatcher } & \mathrm{Nu} \text { FnL2 } \\ \text { Wood thrush } & \mathrm{Nu} \text { TiW5 } \\ \text { Flicker } & \mathrm{Nu} \text { FkN } \\ \text { Hummingbird } & \mathrm{Nu} \text { HuR3 } \\ \text { Wood pewce } & \mathrm{Nu} \text { Pi3 } \\ \text { Chipping sparrow } & \mathrm{Nu} \text { SpC2 } \\ \text { Robin } & \mathrm{Nu} \text { Ro2 }\end{array}$


$e$ Birds that nest on buildings

Robin
Phoebe
Barn swallow
House wren
Cliff swallow
Chimney swift
$\mathrm{Nu}$ Ro7

Nu Pk4

$\mathrm{Nu} \mathrm{SuC4}$

$\mathrm{Nu}$ WrH

$\mathrm{Nu} \mathrm{SuE3}$

$\mathrm{Nu} \quad \mathrm{SwC6}$

\section{$f$ Birds of the marshes}

In the extensive marshes of the State several different zones of vegetation can be recognized, from the open water of the ponds to the dry uplands: first, a fringe of bullrushes and water lilies; second, a growth of cat-tails where the substratum is drier; third, an area of sedges; and fourth, fringing the dry land, an area of marsh grasses. About the marsh there is usually a fringe of willows, alders and button bushes. The birds of the marshes are not limited in their movements to any one area but the majority show a preference in selecting their nesting site. The red-winged blackbird is the most adaptable of all the species and is found nesting in all zones from the alders to the cat-tails.

(1) Bullrush area

Pied-billed grebe

Nu GsP

(2) Cat-tail area

Least bittern

Florida gallinule

Virginia rail

Sor"a rail

Red-winged blackbird

(3) Sedge area

Swamp sparrow

Bittern

Red-winged blackbird

(4) Grass area

Maryland yellowthroat

(5) Alder and willow area

Green heron
$\mathrm{Nu} \quad \mathrm{BiL}$

$\mathrm{Nu}$ GeF

$\mathrm{Nu}$ RV3

$\mathrm{Nu}$ So

$\mathrm{Nu} \mathrm{B} 122$

$\mathrm{Nu} \quad \mathrm{SpS}$

$\mathrm{Nu} \mathrm{BjA}$

$\mathrm{Nu} \mathrm{B} 124$

$\mathrm{Nu} \quad \mathrm{YeM} 4$

$\mathrm{Nu} \mathrm{HeH}$ 


\section{Structure and Habits}

Without going into the origin and evolution of birds as a group from the reptiles and the wonderful changes in their borlily structure which have come about in response to the needs of a flying machine, one can point out many beautiful adaptations of external form which exist today and which fit each bird for the particular life which it leads. It is but necessary to know the kind of food which a bird eats to be able to see how beatufifully nature has modified its bill for securing it. If one knows how the bird pursues its food, he will observe the corresponding adaptations of wings, feet, eyes, etc. The following pictures have been arranged so that one can take up topically the most conspicuous external parts and point out how each is an adaptation for some particular habit. In each case when one has pointed out some particular modification he should encourage the naming of other birds that have similar modifications.

\section{General}

Skeleton of a fowl

$\mathrm{Nu} 4$

Topography of a bird

Nu 2

2 The bill, adapted for different types of food

$a$ Insects, method of securing, and resulting bill

(1) Forceps, for picking small insccts from leaf and twig

Black-throated blue warbler $\quad \mathrm{Nu}$ WB

Yellow-throated virco Nu ViY1

(2) Scoop net, catching them on the wing

Night hawk

Barn swallow

Chimney swilt
$\mathrm{Nu} \quad \mathrm{Ni}$

$\mathrm{Nu} \mathrm{SuC4}$

$\mathrm{Nu}$ SwC6

(3) Awl, picking them from crevices in the bark

Nuthatch

Brown creeper

$\mathrm{Nu} \quad \mathrm{NuW}$

$\mathrm{Nu} \quad \mathrm{CsB}$

(4) Strainer, straining insects from mud and getting aquatic plants

Scaup duck

Canada goose

$\mathrm{Nu}$ DuS

$\mathrm{Nu}$ GpC

(5) Chisel, chopping out from tree trunks and large branches

Red-headed woodpecker

Nu WpS1 
(6) Probe, pulling from soft mud

Woodcock

Yellowlegs

$b$ Seeds

Cracking seeds

House sparrow

Evening grosbeak

Junco

$c$ Fish

(1) Spearing

Belted kingfisher

$\mathrm{Nu} \quad \mathrm{KiB} 7$

Common tern

Heron
$\mathrm{Nu} \quad \mathrm{Wo6}$

Nı Yd
Nu SpI6

Nu GtE7

Nu JuS

(2) Scooping

Brown Pclican, Bill and Pouch. Pclican island, Florida (1898) Chapman

Brown pelican, habitat group $\quad \mathrm{Nu}$ PfB1

(3) Tearing carrion or large fish caught by the feet
Gulls
$\mathrm{Nu} \quad \mathrm{GvH} 8$
Gulls
$\mathrm{Nu} \quad \mathrm{GvH} 1$
Osprey
$\mathrm{Nu}$ Os

$d$ Flesh of birds or rodents

Hook-always caught by feet and then torn to pieces by bill

Bald eagle

Sparrow hawk
$\mathrm{N}_{11}$ EB57

$\mathrm{Nu} \mathrm{HT}$

3 The wing, uses and adaptations

a Flight

(1) Sudden burst of speed, short and rounded, stiff Canada grouse $\mathrm{Nu} \quad \mathrm{GuC}$

(2) Long-continued sailing, long and narrow

Herring gull

$\mathrm{Nu} \quad \mathrm{GvH7}$

Marsh hawk

$\mathrm{Nu}$ HM7

(3) Soaring, long and broad

Turkey vulture

Bald eagle

$\mathrm{Nu} \quad \mathrm{VuT}$ 8

$\mathrm{Nu}$ EB 
(4) Speed, broad at base, pointed tip
Bank swallow
Nu $\quad$ SuB6
Sparrow hawk
Nu HT8

(5) Weak fliers, short, rounded, soft

Virginia rail

Nu1 RV9

(6) Lack of use, wings degenerate
Auk
Nt1 Al1

$b$ Brooding - a secondary use, producing no special adaptation Veery

$\mathrm{Nu} \quad \mathrm{Ve6}$

c Defense

(1) In those species in which the wings are used actively as defense organs spines or knobs are developed upon them. The Canada goose has knobs at the bend of wing and severe blows can be dealt with them

(2) In some birds the wings are used secondarily to shield themselves and to frighten the enemy Great horned owl threatening

$\mathrm{Nu} \quad$ OwG1

4 The tail

$a$ Rudder

Tree swallow

Nu SuT6

$b$ Brake

Baldpate

Osprey

$\mathrm{Nu} \quad \mathrm{Bc} 1$

$\mathrm{Nu} \quad \mathrm{Os} 8$

$c$ Prop

Downy woodpecker $\quad \mathrm{Nu} \quad \mathrm{WP}_{\mathrm{P}} \mathrm{D}$

Brown creeper $\quad \mathrm{Nu} \mathrm{CsB}$

5 The feet

$a$ Perching, three toes forward, one backward Crow

$\mathrm{Nu} \quad \mathrm{Cu} 6$

$b$ Wading

Young blue heron

Young blue heron

$\mathrm{Nu} \mathrm{HeF} 44$

$\mathrm{Nu} \mathrm{HeF} 8$

c Swimming

Pintail

Grebe, young swimming

$\mathrm{Nu} \quad \mathrm{Pn}$

$\mathrm{Nu} \quad$ GsP6 
$d$ Diving

Canvasback

$\mathrm{Nu} \mathrm{Cal}$

Canvasback, flock swimming

$\mathrm{Nu} \mathrm{Ca} 6$

$e$ Running and scratching

Ring-necked pheasant

$\mathrm{Nu} \quad \mathrm{PjR}$

$f$ Defense

Ring-necked pheasant

Nu PjR7

$g$ Catching prey

Duck hawk

$\mathrm{Nu}$ HD5

$h$ Rudder

Scaup duck

Nu DuS9

Bittern

$\mathrm{Nu}$ BiA9

$i$ Lack of use bringing on degeneration

Kingfisher

$\mathrm{Nu} \quad \mathrm{KiB} 6$

Nighthawk

$\mathrm{Nu} \mathrm{Ni} 7$

6 The eyes

a Position and significance

(1) Normal, on sides of head, seeing distinctly on either side, 180 degrees, without turning head; enemies come from any direction

Wood thrush

$\mathrm{Nu}$ TiW6

(2) Both directed forward as in man, must turn head to see; such birds usually sit with back to trunk of a tree
Great horned owl
Barn owl
$\mathrm{Nu} \mathrm{OwG}$
$\mathrm{Nu} \mathrm{OwB}$

(3) Eyes somewhat dorsal, can see above and backward; enemies come from above

Woodcock

$\mathrm{Nu}$ Wo

(4) Eyes somewhat ventral, in order to see when peculiar pose is assumed in the presence of enemies

Least bittern

Nu BiL7

$b$ Size and significance

Nocturnal birds and those living in dark woodlands have larger eyes than those working by day and in bright open country. 
(1) Nocturnal

Screech owl

$\mathrm{Nu} \quad \mathrm{OwS} 4$

(2) Diurnal bird

Sparrow hawk

Nu HT4

This is a bird of about the same size as the screcch owl. Compare as to eyes.

(3) Woodland

Canada warbler

$\mathrm{Nu} \quad \mathrm{WC}$

(4) Open country

Yellow warbler

Coloration

$\mathrm{Nu} \quad \mathrm{WY}$

The subject of the coloration of birds introduces one to many of the most difficult problems in bird study. There are several factors which control the coloration of birds. Birds of the same species vary in color with sex, with age and with season.

\section{Color and sex}

With some species the sexes are both alike, either both bright or both dull ; with other species, the male is bright and the female dull. There are a few species, particularly the phalaropes, where the female is brighter than the malc. This might be considered the case with the kingfisher, for the female has a rich rufous band across her breast that the male lacks, while in other points of plumage they are alike.

$a$ Male and female alike-dull

Song sparrows, a pair

Chipping sparrows, a pair

Nu SpR1

$\mathrm{Nu} \quad \mathrm{SpC}$

$b$ Male bright, female dull

Indigo bunting, male

$\mathrm{Nu}$ BuI

Indigo bunting, female

Rose-breasted grosbeak, male

$\mathrm{Nu}$ BuI2

Rose-breasted grosbeak, female

$\mathrm{Nu} \quad \mathrm{GtR}$

$\mathrm{Nu}$ GtR3

$c$ Male and female both bright or strikingly marked

Red-headed woodpecker, may be either male or feimale

$\mathrm{Nu}$ WpS

Chickadee, may be either male or female $\mathrm{Nu}$ Ci9

$d$ Male and female, both bright, female brighter than male

Kingfisher, female

$\mathrm{Nu} \quad \mathrm{KiB6}$ 


\section{Color and age}

When the parents are alike, the young usually resemble them, even though they may be bright colored. Young red-headed woodpeckers are an exception to the rule because if the coloration of the parents is a departure from that of the family, the young usually resemble the family type. When the parents are different, the young resemble the female.

a Parents alike, young similar

$\begin{array}{lll}\text { Song sparrow and young } & \mathrm{Nu} & \text { SpR5 } \\ \text { Kingfisher, immature } & \mathrm{Nu} & \mathrm{KiB} 6 \\ \text { Kingfisher, adult } & \mathrm{Nu} & \mathrm{KiB7}\end{array}$

$b$ Parents alike, young different

Adults have departed from coloration typical of family

Chipping sparrow and young

Red-headed woodpeckers, young

Red-headed woodpecker, adult

$c$ Parents different, young like female

Red-winged blackbirds, young

Red-winged blackbird, male

Red-winged blackbird, femalc
$\mathrm{Nu} \quad \mathrm{SpC} 4$

$\mathrm{N}$ i $\mathrm{WpS4}$

$\mathrm{Nu} \quad \mathrm{WpS}$

$\mathrm{Nu} \quad \mathrm{B} 14$

$\mathrm{Nu} \quad \mathrm{Bl}$

$\mathrm{Nu} \quad \mathrm{B} 11$

\section{Color and season}

When there is a difference in coloration between the male and female, after the breeding season the male usually assumes the coloration similar to that of the female. This has to be changed again during the winter or spring to bring him once more into his breeding plumage.

$a$ Change in color of adults in spring and fall

(1) By molting

$\begin{array}{lll}\text { Pintail, male, spring } & \mathrm{Nu} & \mathrm{Pn} \\ \text { Pintail, male, early fall (eclipse plumage) } & \mathrm{Nu} & \mathrm{Pn} 2 \\ \begin{array}{l}\text { Wild mallard, early fall (eclipse plumage) } \\ \text { Wild mallard, male, late fall (spring }\end{array} & \mathrm{Mc12} \\ \begin{array}{l}\text { plumage) } \\ \text { plu }\end{array} & \mathrm{Mc14} \\ \text { feather wear } & - & \end{array}$

In a few cases the conspicuous marks of the breeding plumage are borne by the male during the winter, veiled by gray or brown edging to the feathers. The bright marks of the breeding plu- 
mage are acquired merely by wearing off these gray edges. The black bib of the male house sparrow is a good example.

$$
\begin{array}{lll}
\text { House sparrow in winter and early spring } & \mathrm{Nu} & \mathrm{SpI} \\
\text { House sparrow in summer } & \mathrm{Nu} & \mathrm{SpI} 1
\end{array}
$$

\section{Dichromatism}

In a few species of birds there are two color phases irrespective of age, sex or season. They often occur in the same brood of young. The red and gray phases of the screech owl are the best example. It is probable, likewise, that the Cory's least bittern represents a color phase of the least bittern.
Screech owl, gray phase
$\mathrm{Nu} \quad \mathrm{OwS}$
Screech owl, red phase
$\mathrm{Nu} \quad \mathrm{OwS7}$

\section{Albinism}

In individuals of any species a weakness in pigment is likely to occur resulting in pale or white feathers. Pure albinos, with no pigment whatever, occasionally occur in all species.

\section{Normal and albino robins}

$\mathrm{Nu}$ Ro95

\section{Protective coloration}

One of the most interesting phases of the coloration of birds is that of "protective coloration." The majority of birds are inconspicuous in their natural haunts that they may more easily escape their enemies. Nature renders them inconspicuous in a variety of ways.

\section{$a$ Counter shading}

The most universal method by which birds are inconspicuously colored is called "counter-shading," which may be briefly explained thus: All solid objects out of doors cast shadows on their underparts. So universally is this true that the eye depends upon the shadow to judge whether an object is a solid or a plane. If the shadow is counteracted by lighter coloring in direct proportion to the amount of the shading, the object will appear flat, apparently lose its solidity and cease to stand out away from its background. If the object at the same time is the color of the background it will apparently become a part of it and not be noticed as an entity. In the accompanying photographs of models, two blocks of exactly the same size and colored uniformly dark were placed on a gravel walk. The great bird artist Louis A. Fuertes then added white paint to the underparts of 
one model in direct proportion to the amount of shadow and sufficient to the back to give it the general color pattern of the background. The result as shown is that the "counter shaded" model is almost invisible and one must put a white sheet of paper behind it in order to see it. It is interesting to note that the model when complete was the almost exact duplicate of the redbacked sandpiper in fall plumage. If the counter-shaded model is turned upside down so that the white belly receive the most light, it becomes even more conspicuous than the uniformly colored one.

Study in Counter Shading. Models made by Louis Agassiz Fuertes; photographed by H. D. Reed. (1906)

$\mathrm{Nu} \quad \mathrm{ZC} 2$

(1) Models right side up, normal background

The counter shaded model is just behind the uniformly colored one, but is almost invisible.

(2) Models right side up, white cardboard underneath

Note how the counter shaded model on right becomes conspicuous when light comes from other direction than above.

(3) Models with partial white background

Showing that it is necessary for the color pattern of the counter shaded model to be similar to the background to become invisible; also how the solidity of the counter shaded model is apparently destroyed and made to appear perfectly flat even against the white background.

(4) Models upside down with normal background

Showing how counter shaded model becomes more conspicuous than the uniformly colored one when in this position.

$\begin{array}{lll}\text { Pectoral sandpiper walking on shore } & \mathrm{Nu} & \text { SP } \\ \text { Least sandpiper at water's edge } & \mathrm{Nu} & \text { SL } \\ \text { Semipalmated sandpiper wading } & \mathrm{Nu} & \text { SR }\end{array}$

$b$ Color patterns-usually plus counter shading

Counter shading alone not being sufficient entirely to obliterate the appearance of the bird, the color of it must match its background. And so we find in nature that the field birds are streaked like the lights and shadows between the grasses, many of the marsh birds are striped, the terrestrial woodland birds are more or less mottled, etc. 
Savannah sparrow, grass pattern

$\begin{array}{ll}\mathrm{Nu} & \mathrm{SpP} 3 \\ \mathrm{Nu} & \mathrm{BiL} 8 \\ \mathrm{Nu} & \text { Wo6 } \\ \mathrm{Nu} & \mathrm{GuR7} \\ \mathrm{Nu} & \mathrm{GvH4} \\ \mathrm{Nu} & \mathrm{OwS} 1 \\ \mathrm{Nu} & \mathrm{Ke5} \\ \mathrm{Nu} & \mathrm{Ni6}\end{array}$

Least bittern, reed pattern

Woodcock, dead leaf pattern

Ruffed grouse, dead leaf pattern

Young gulls, rock pattern

Screech owl, bark pattern

Young killdeer, sand and gravel pattern

Nighthawk, ground pattern

Nu Ni6

\section{c Banner marks, or flash colors}

Another principle of protective coloration is what has been called "flash colors," or "banner marks," consisting of bright conspicuous markings which the bird can conceal at will. Ordinarily, like the white rump or white outer tail feathers of some birds, they are conspicuous in flight but out of sight when the bird is at rest. They serve in a protective way in this manner: the eye of the pursuing enemy is attracted by the most conspicuous mark and pursues it. When of a sudden the bird drops to the ground, the eye through the persistence of vision continues to follow in the direction the bird was going long enough to allow the bird to slink off and disappear.

$\begin{array}{lll}\text { Meadowlark, white tail feather } & \mathrm{Nu} & \mathrm{Mf} \\ \text { Gallinule, white flanks and under tail coverts } & \mathrm{Nu} & \mathrm{GcF} \\ \text { Nuthatch, black and white markings } & \mathrm{Nu} & \mathrm{NuW} 9\end{array}$

\section{$d$ Ruptive markings}

Ruptive marks are likewise conspicuous in themselves but serve as a protective device. They consist of conspicuous markings usually black and white, closely opposed: such as a white ring around the neck, a black band across a white breast, etc. The sharp contrasts serve to destroy the continuity of outline, cut the bird into several pieces and make it appear unbirdlike.

\footnotetext{
Killdeer, white ring

Kingfisher, white ring

Pheasant, white ring

Teal, white bar
}

$\begin{array}{ll}\mathrm{Nu} & \mathrm{Ke} 2 \\ \mathrm{Nu} & \mathrm{KiB} 7 \\ \mathrm{Nu} & \mathrm{PjR} \\ \mathrm{Nu} & \mathrm{TeG}\end{array}$

\section{e Mimicry}

The preceding principles apply to coloration alone. If at the same time there occurs a modification of the shape of the bird either by means of crests or "horns" or merely the position or attitude assumed by the bird, the effect is called mimicry. Thus when a gray screech owl compresses its feathers and raises its ear tufts, it simulates in shape a broken stub and its coloration 
matches that of the bark. When the least bittern points its bill toward the zenith and compresses its neck feathers, it simulates a broken reed, for at the same time its body is flattened and ruptive marks cut it off from the neck or reed portion. In the same way the waxwing simulates a dead leaf and the nighthawk a branch broken off short.

Least bittern, broken reed posture Waxwing, freezing

Nighthawk

$$
\begin{array}{ll}
\mathrm{Nu} & \mathrm{BiL7} \\
\mathrm{Nu} & \mathrm{Wg} 8 \\
\mathrm{Nu} & \mathrm{Ni7}
\end{array}
$$

\section{How to Attract}

Attracting birds to the house and school surroundings is of value not only because insects and weed seeds are thus destroyed in these places, but because of the pleasure that is derived from having the birds about and from the response which they give to a little kindness and protection. One of the easiest methods of getting and keeping children interested in birds is to lead them to make some effort to assist the birds to get a home and food. When the birds come to the feeding station and become tame and even eat from the hand, an instructor becomes almost unnecessary. When a boy builds a bird box and a pair of bluebirds nest in it, he will watch those birds and learn more than from the classroom.

\section{Feeding the birds}

\section{a Winter feeding}

One should start early putting out food so the birds will find it before November, before they have established the regular routes which they follow during the winter.

(1) Putting out suet

insect-eating birds, like woodpeckers, nuthatches and chickadees, are fond of beef suet or oily seeds. The suet may be tied to the branches or, if crows and squirrels abound, rammed into holes bored in the tree or placed behind one-half inch wire netting tacked to the tree. Several pieces of suet should be put out so arranged that the birds will at last find one placed near the window.

$\begin{array}{lll}\begin{array}{l}\text { Downy woodpecker at suet tied to branch } \\ \text { Red-bellied woodpecker }\end{array} & \mathrm{Nu} \text { Wp8 } \\ \begin{array}{ll}\text { Hairy woodpecker eating suet on window } \\ \text { casing }\end{array} & \mathrm{Nu} \text { WpR } \\ \text { Flicker } & \mathrm{Nu} \text { WpH } \\ \text { Chickadee } & \mathrm{Nu} \text { FkN1 } \\ \text { Nuthatch } & \mathrm{Nu} \text { Ci } \\ & \mathrm{Nu} & \mathrm{NuW} 4\end{array}$




\section{(2) Putting out seed}

When school opens in the fall, it is time to get ready the feeding stations, building the food shelf or the window box. Seed-eating birds prefer cracked grain, millet, hay seed from the barn floor, or weed seed that may be gathered. Such food should be scattered on the ground where the birds ordinarily feed and also on the food shelf at or near the window, where they will sooner or later find it.

Scattered on snow where birds feed

$\begin{array}{lll}\text { Juncos } & \mathrm{Nu} & \mathrm{JuS} 9 \\ \text { Song sparrow } & \mathrm{Nu} & \mathrm{SpR} 8\end{array}$

Feed log or shelf

Tree sparrow

$\mathrm{Nu} \quad \mathrm{SpT} 8$

Evening grosbcak

$\mathrm{Nu}$ GtE9

Feeding devices

Food shelf on post

$\mathrm{Nu} \quad \mathrm{Ci} 84$

Window box

$\mathrm{Nu} \quad \mathrm{Ci} 82$

$b$ Spring feeding

Keep up the winter feeding through the spring and many migrants will come to the feeding station

$\begin{array}{ll}\text { Robin } & \mathrm{Nu} \text { Ro6 } \\ \text { Fox sparrow } & \mathrm{Nu} \text { SpG } \\ \text { Whitc-crowned sparrow } & \mathrm{Nu} \text { SpW } \\ \text { Song-sparrow and whitc-throat } & \mathrm{Nu} \text { SpR72 } \\ \text { Chipping sparrow } & \mathrm{Nu} \text { SpC } \\ \text { Cardinal } & \mathrm{Nu} \mathrm{Cb} \\ \text { Cowbirds } & \mathrm{Nu} \text { Co }\end{array}$

$c$ Response of birds to feeding

Chickadee on hand of Doctor Allen $\quad \mathrm{Nu}$ Ci86

Chickadee on hand of a lady $\quad$ Nu Ci88

Mrs Allen feeding scaup ducks $\quad \mathrm{Nu} \quad \mathrm{DuS} 8$

2 Nesting boxes

Nest boxes should be in place by the first of March; so one should begin early with the construction of them, especially if one is planning a competition among the children. The boxes should be correctly built, emphasis being given to the size and position of the opening, as these are of prime importance; the strength of the box, the method of fastening, means of cleaning and the placing of the box also need special attention. If a box 
is hung in the middle of a shady tree, it stands very little chance of getting a tenant; while if it is on a pole in the open or very light shade, it has a much better chance.

$a$ Structure

Incorrectly Built Boxes

Correctly Built Boxes

$\mathrm{Nu}$ ZB1

$\mathrm{Nu}$ ZB2

$b$ Putting up bird boxes

Bird Boxes Made by School Children and Being Put $U_{p}$ in the Cayuga Bird Club Sanctuary. Renwick. (May 7, 1915) Allen Nu ZB9

c Types for different birds, properly built and properly placed

Wren, hole $3 / 4-1 \mathrm{x} / 4$ inches, any sort of box
Wren box, on porch
Crested flycatcher, hole $2-2 \mathrm{x} / 2$, box $5 \times 5 \times 8$,
poorly placed in tree but occupied
Two Boxes on Posts Properly Placed;
Nearer One, Inhabited by House Wren,
Second One, by Crested Flycatcher
Purple martin, hole $2 \mathrm{x} / 2$ inches; only house
that should have more than one compart-
ment, placed on post $18-20$ feet from
ground
$\mathrm{Nu} \quad \mathrm{WrH}$ $\mathrm{Nu}$ WrH9 $\mathrm{Nu} \quad \mathrm{FnC5}$

$\mathrm{Na} \quad$ ZB3

$\mathrm{Nu} \quad \mathrm{MeP} 9$

3 Furnish nesting material

About the middle of May when the orioles, yellow warblers and chipping and song sparrows are thinking of nesting, encourage the putting out of pieces of cotton and short pieces of lightcolored string or yarn and horse hair from old upholstery. An abundance of nesting material will encourage the birds to nest in the vicinity.
Cotton, yellow warbler
$\mathrm{Nu}$ WY3
Cotton in indigo's nest
$\mathrm{Nu} \quad \mathrm{BuI} 5$
Oriole and strings
$\mathrm{Nu} \quad \mathrm{OrB} 2$
Tree swallow with feather in bill
$\mathrm{Nu}$ SuT3

4 Plant seed-bearing plants in the garden

When Arbor Day arrives, encourage the planting of mulberries, mountain ash, Virginia creeper, dogwood and other shrubs, vines or trees that will bear fruit attractive to birds, and when the gardens are planted put in a little piece of millet and a row of sunflowers for the birds.

Sunflowers and chickadee

$\mathrm{Nu} \quad \mathrm{Ci} 96$

Sunflowers and goldfinch

$\mathrm{Nu}$ Go 
5 Plant fruit-bearing trees, shrubs and vines

Mountain ash and cedar waxwing

Nı Wg6

6 Supply water for drinking and bathing

When the hot weather comes, the birds will need water. $\Lambda$ shallow pan placed on a post in the yard where the water can be replenished will attract many birds. If running water is available or if a more elaborate bird bath is feasible, so much the better. The birds will appreciate it at all seasons of the year, even in winter if it is not frozen.

\section{Drinking log or pan}

Wood pewee

Catbird

Robin

Bird Fountain in Garden of Prof, and Mrs
$\begin{array}{ll}\mathrm{Nu} & \mathrm{Pi} \\ \mathrm{Nu} & \mathrm{Cd} 6 \\ \mathrm{Nu} & \mathrm{Ro5}\end{array}$

J. N. Comstock. Ithaca. (July 20, 1915)

Allen $\mathrm{Nu}$ ZD2

7 Care for cats

Cat with Young Bird in Its Mouth. (1917) Nu ZT4

There are several other things that can be done to attract birds. First and foremost, is caring for all cats. Pets should be properly fed and cared for and all stray cats should be humanely killed.

\section{Flight}

When one studies the structure of a bird, one is immediately impressed by the wonderful modifications that have been evolved to fit the bird for flight. The bird's body, its arms and legs, its head and feet, its skeleton, its muscles and tendons, its innermost parts and its outermost covering are all highly specialized parts of a flying machine. All the features which man has found necessary to emphasize in constructing the modern airplanes, nature perfected when she transformed through thousands of years an ungainly reptile into the graceful bird that we know today.

An airplane requires in the first place great lightness, as great as is compatible with strength, and there must be no loose ends. It must be compact. The materials must be the strongest for their weight that can be secured. And so we find with the bird, the heavy reptilian bones have become hollow, the platelike bones of the skull, very thin, and the jaws with their heavy muscles 
have transferred their labors to the bird's gizzard so that the jaws may be very light, and there are no teeth. The head is relatively small and the legs are slender. The body is covered with buoyant feathers and there are air sacks connected with the lungs that add to the buoyancy of the bird's body. Compactness is brought about by shortening the body and fusing the vertebrae; by firmly fastening the ribs to the breastbone as well as to the backbone and furnishing them with interlocking processes. The heavy muscles that move the wings and legs have been moved toward the center of equilibrium, those of the wings to the breastbone and those of the legs to the thighs. Only the tendons are found on the outer joints of wings and legs. The tail vertebrae are much shortened and fused to form one bone, the pygostyle, upon which the feathers are borne. The heavy internal parts like the heart, liver, gizzard and intestines are likewise moved toward the center of equilibrium and all are hung beneath the wings much as the body of an airplane is supported.

This compactness adds to the bird's strength and permits of the attachment of the huge masses of muscle to the breastbone for manipulating the wings. The bird's feathers are said to be the strongest substances of their size and weight in the world.

1 Structure

Skeleton of a fow 1

$\mathrm{Nu} 4$

Examine the skeleton of the fowl with regard to the above points.

\section{$a$ The wings}

Topography of a bird

$\mathrm{Nu} 2$

The bird's arms are its wings, similar to man's except that the bones of the wrist and hand have become fused for strength. Only the thumb, first and second fingers have been preserved and only the first finger is important. On the fused hand are borne the longest flight feathers called the primaries; on the forearm are borne the next longest flight feathers called the secondaries. The few long feathers lying next to the body when the wing is extended are borne on the upper arm and are called the tertiaries.

Black-crowned night heron

$\mathrm{Nu} \mathrm{HeB} 5$

Examine the spread wing and classify the feathers 
Bluebird

$\mathrm{Nu} \quad \mathrm{Bm} 8$

Identify the different groups of wing feathers and note the spurious wing. The thumb bears a tuft of short feathers, called the spurious wing, that can sometimes be seen along the front margin of the extended wing.

Killdeer

$\mathrm{Nu} \mathrm{Ke} 9$

Note how the wing is bent at the wrist and decide in which direction the wing is moving. The joints of the wing have become very firm and strong but there is still considerable flexibility to the wrist joint. When the wing is brought upward on the noneffective stroke, this joint is bent and the wing partially folded so that there will be an angle to cut the air. On the downward stroke the wrist joint is held immovable and the wing rigid.

Black tern

$\mathrm{Nu}$ TfB6

Compare with the preceding and determine in which direction the wing is moving.

Yellowlegs $\quad \mathrm{Nu} \quad \mathrm{Yd} 8$

Here the birds are about to alight and the wings are considerably arched and probably being held in the one position. Note the position of the legs as a further indication.

\section{$b$ The legs}

The bird's legs differ from man's chicfly in that the ankle bones have become fused into one bone, and this greatly elongated to form what is called the tarsus. This is ordinarily the most conspicuous part of the bird's leg since the thigh bone lies against the body beneath the skin and the shin bone is ordinarily almost concealed by the bird's breast feathers. The muscles of the legs are mostly borne on the thigh bone and thus brought toward the center of gravity. A few muscles are borne on the shin but only tendons are found along the tarsus and toes. The muscles of the legs give the initial spring which lifts the bird into the air. They are then ordinarily folded back under the tail or if very long held straight out behind. In a few birds with rudimentary tails, the feet probably assist in steering and in checking flight.

American bittern

Nu BiA8

Note the extended legs and identify the various parts. The bird is just springing from the marsh and will later hold its legs straight out behind. 
American bittern

$\mathrm{Nu} \quad \mathrm{BiA9}$

Note legs being lifted to normal position during flight. Note also position of wings and determine their direction of movement.

Green heron

$\mathrm{N} 11 \mathrm{HeH8}$

Compare with the preceding.

Canvasbacks

Nu Ca9

Heavy bodied, short legged birds have difficulty in rising. Note the positions of the feet and also of the wings in the different birds.

Scaup ducks

Nu DuS9

The tail of the duck is poorly developed. Note how the webbed feet are being used as rudders.

Baldpate

$\mathrm{Nu} \quad \mathrm{Bc} 1$

This bird is about to alight and its feet are used to help check the momentum. Compare with preceding.

Mallards

$\mathrm{Nu} \quad \mathrm{Mc} 82$

Note the position of the feet and decide whether the birds are just starting flight or have been under way for some time.

Mallard

$\mathrm{Nu} \mathrm{Mc} 84$

Compare with the preceding and make same decision.

$c$ The tail

The tail of a bird, aside from the feathers borne upon it, is a short compact structure showing the same tendency to bring all weight toward the center of equilibrium. The number of feathers borne upon it varies with different species, but in all perching birds the number is twelve. In the earliest known birds (the archæopteryx) the tail was long like a lizard's and the feathers were borne along each side. The shortening of this structure has doubtless aided the power of flight. The tail is the steering organ during flight and a bird without a tail is like a ship without a rudder. It is likewise used to check the bird's momentum when it is about to alight.

Tree swallow

$\mathrm{Nu} \quad \mathrm{SuT6}$

The bird started for its nesting hole but swerved just as the photographer snapped it. Note the position of the tail. 
Osprey

$\mathrm{Nu}$ Os8

This bird is alighting on its nest and the tail is spread to check the momentum.

Marsh hawk

$\mathrm{Nu}$ HM8

Compare with the preceding.

2 The uses of the wings

There are five different types of flying for which there are as many types of wings, the different birds being best adapted for one particular method of flying.

\section{$a$ Ordinary flight}

This is accomplished by a rhythmic up and down motion of the wings held at such an angle that the resultant of the forces drives the bird forward. The best type of wing for ordinary flight is one of average proportions such as already seen in the bluebird ( $\mathrm{Nu} \mathrm{Bm8)}$ and night heron (Nu HeB5).

\section{$b$ Sailing}

Accomplished by holding the wings outstretched at such an angle that, without any motion, the resultant of the forces of wind and gravity drives the bird ahead. Birds that depend upon this method of locomotion often remain on the wing for long periods. The best type of wing is a long narrow one, carried to the extreme in the albatrosses but illustrated in many North American birds.

Caspian terns

$\mathrm{Nu} \quad \mathrm{TfC} 6$

These birds are sailing over their nesting island. Note the length of wing as compared with the length of body and the width of wing. The wings of all the birds are in nearly the same positions, indicating that they must be holding them in a uniform position.

Sooty tern

Nu TfS7

Note the position of the wings. These birds can balance themselves on the wind for hours at a time without any apparent motion of their wings.

Common tern

$\mathrm{Nu}$ TfD

Note the great length of the wing. 
Marsh hawk

Nu HM7

The marsh hawk finds its food of mice by sailing back and forth over the meadows (sailing not soaring). The sixth primaries have apparently been molted and are being replaced.

Black tern

$\mathrm{Nu}$ TfB 9

Compare with the preceding, noting the long wings.

$c$ Soaring

Accomplished by holding the wings and tail at such an angle that without any apparent movement, the bird is able to take advantage of air currents and sail in large circles, rising higher and higher. For this method of flight, a large broad wing and fanlike tail are necessary.

Bald eagle

$\mathrm{Nu} \quad \mathrm{EB}$

The eagle and all the broad winged hawks (Buteos) spend much time soaring high over head watching the ground for prey. Note the breadth of wing and the fanlike tail.

Young bald eagle

$\mathrm{Nu} \quad \mathrm{EB} 1$

Compare with the preceding.

Young bald eagle

$\mathrm{Nu}$ EB52

The wings of the eagle are so heavy that for many weeks after they are full grown the young bird is unable to hold them up.

Turkey vulture

$\mathrm{Nu} \quad \mathrm{VuT} 4$

Note the great expanse of wing.

Turkey vultures

$\mathrm{Nu}$ VuT8

These birds are just getting under way when they are at some disadvantage because of their large wings. The "buzzards" soar for hours at a time with apparently no effort.

\section{$d$ Darting}

Accomplished by suddenly increasing the wing strokes over normal flight and is used by birds in pursuing flying insects, other birds, or in escaping enemies. The shorter the wing the more rapidly it can be moved and in birds that must gain sudden momentum from a stationary position we find the shortest wings, as in members of the grouse family. In birds that have longer wings and must take flight suddenly, the effect of a shorter wing that can be moved much more rapidly is brought about by spreading the primary feathers. 
Canada grouse

$\mathrm{Nu} \quad \mathrm{GuC}$

The grouse spend most of their time on the ground but when alarmed take flight and are almost immediately at full speed. They can do this because of their short wings. Such tremendous effort can not be kept up long and they usually do not fly far. Note the short wings of this bird.

$$
\text { Pintails } \quad \mathrm{Na} \quad \mathrm{Pn} 8
$$

These birds are just taking flight as may be judged by the position of the feet. Note how the primaries of the rear bird are spread.

Flicker

$\mathrm{Nu} \quad \mathrm{FkN8}$

Note the spread primaries and draw conclusions.

$e$ Speed

Accomplished, as in darting, by an increase in the number of wing strokes. If the speed is to be maintained for any length of time, a very short wing is too fatiguing, so some birds have developed pointed wings of greater length. The most powerful flyers, such as the falcons, swallow and shore birds, belong to this class.

Sparrow hawk

$\mathrm{Nu} \quad \mathrm{HT} 8$

The sparrow hawk is one of the falcons.

Barn swallow

$\mathrm{Nu} \quad \mathrm{SuC4}$

Note the long-pointed wings. The tail also is always well developed in this group of swift-flying birds.

Bank swallows

$\mathrm{Nu} \quad \mathrm{SuB6}$

Compare with the preceding. The bank swallows are less powerful flyers than the barn swallows. Why?

Purple martins

$\mathrm{Nu} \quad \mathrm{MeP8}$

Compare with the preceding and make deductions.

Semipalmated sandpipers

$\mathrm{Nu} \quad$ SR8

Although so very different when at rest from the swallows, when on the wing they appear quite similar. Why?

Least sandpiper

$\mathrm{Nu} \quad$ SL8

Compare with the preceding.

Red-breasted merganser

$\mathrm{Nu} \quad \mathrm{MhR} 8$

Note the shape and relative length of wing. 
The ducks have rather short pointed wings and they, too, can develop great speed. The diving ducks, like the scaups and canvasbacks, that fly relatively short distances and depend more upon diving for safety, have shorter wings than the dabbling ducks, like the black ducks and baldpates, that fly longer distances to their feeding grounds and depend entirely upon flight for safety.

\section{Scaup ducks}

$\mathrm{Nu} \quad \mathrm{DuS7}$

Compare with the preceding, making similar observations. Both the scaups and mergansers are "diving ducks," although the mergansers do not belong in subfamily Fuligulinae, which are the real diving ducks.

$$
\text { Baldpates } \quad \mathrm{Nu} \mathrm{Bc} 8
$$

The baldpates are dabbling ducks. Compare with the preceding. The difference in relative length of wings is not great, but it is observable.

Black ducks

$\mathrm{Nu} \quad$ DuB8

Compare with the preceding slides and determine from the photograph alone in which group of ducks the black ducks belong.

Geese

$\mathrm{Nu} \quad \mathrm{GpC} 9$

In which group would you put the geese?

A short, narrow wing requires incessant beating to drive the bird along and such we find in the hummingbirds, whose wings vibrate so fast as to be indistinguishable.

Hummingbird

$\mathrm{Nu} \quad \mathrm{HuR}$

In hovering before flowers, even as in direct flight, the wings are moved so rapidly that the camera records only a blur even in $1 / 500$ of a second.

3 Disuse of wings

When the bird does not use its wings very much or learns to find its food and escape its enemies without them, the wings become weak and more or less useless. Some birds, indeed, have entirely lost the power of flight and depend wholly upon diving or hiding.

\section{Virginia rail}

Nu RV9

The rails live in the marshes where they are able to skulk and hide in the marsh vegetation and seldom have to fly. Their 
wings have become short and rounded and the feathers much softer than ordinary flight quills.

Holboell grebe $\quad \mathrm{Nu}$ GsH

The grebes are expert divers and always seek safety from their enemies by diving. Note the shortness of the wings.

Great auk

$\mathrm{Nu} \quad \mathrm{AuG}$

See note on page 8 .

\section{Migration}

The study of bird migration is one of the most fascinating branches of bird study. The air of mystery that pervades the travels of birds over thousands of miles of land and sea, and the cheery songs that announce their arrival in the spring have furnished the inspiration that has led thousands of men, women and children to the study of nature. Many of the phenomena connected with the migration of birds, such as the height and speed of their flight, the origin of their migrating instinct and how they find their way, can not be illustrated with pictures but many of the facts can, and the inspiration that comes to people with the first arrival of birds in the spring should be used to inspire them to pursue the subject of migration further than the mere naming of the different birds as they arrive. Emphasis should be laid upon the definiteness and the regularity of their movements. A chart should be kept preserving arrival dates of the different species each year.

1 Nonmigrants or permanent residents: ${ }^{2}$ those that do not migrate at all

"Other winter birds represented in this collection are:

Permanent residents:

Bobwhite
Ruffed grouse
Red-shouldered
hawk
Red-tailed hawk
Sparrow hawk
Cooper hawk
Winter visitants:
Saw-whet owl
Prairie horned lark
Lapland longspur
Junco

Screech owl

Barred owl

Great horned owl

Long-eared owl

Short-eared owl

Crow

Blue jay

Tree sparrow

White-throated

sparrow
Flicker

Meadowlark

Hairy woodpecker

House sparrow

Song sparrow

Goldfinch

Cedar waxwing

Northern shrike

Snow bunting

Brown creeper 


$\begin{array}{lll}\text { Chickadee in winter } & \mathrm{Nu} & \mathrm{Ci} \\ \text { Chickadee in summer } & \mathrm{Nu} \text { Ci96 } \\ \text { Nuthatch in winter } & \mathrm{Nu} \mathrm{NuW9} \\ \text { Nuthatch in summer } & \mathrm{Nu} & \mathrm{NuW} 2 \\ \text { Downy woodpecker in winter } & \mathrm{Nu} \text { WpD } \\ \text { Downy woodpecker in summer } & \mathrm{Nu} \text { WpD5 }\end{array}$

\section{Migrants}

According to the extent of their migration, several groups of migrants are recognized.

$a$ Winter residents; spend summer in far north, come south as far as New York State in winter

\begin{tabular}{|c|c|}
\hline Tree sparrow & $\mathrm{Nu}$ \\
\hline Snow bunting & $\mathrm{Nu}$ \\
\hline Lapland longspurs & $\mathrm{Nu}$ \\
\hline Canvasbacks & $\mathrm{Nu}$ \\
\hline Scaup ducks & $\mathrm{Nu}$ \\
\hline
\end{tabular}

$b$ Summer residents: spend the nesting period in New York State but migrate further south for the winter
Bluebird
$\mathrm{Nu} \quad \mathrm{Bm}$
Yellow warbler
$\mathrm{Nu}$ WY
Chipping sparrow
$\mathrm{Nu} \quad \mathrm{SpC3}$
Baltimore oriole
$\mathrm{Nu}$ OrB
Red-eyed vireo
$\mathrm{Nu} \mathrm{ViR}$

$c$ Transient visitants: spend the summer north of New York State and the winter south of it, passing through on the way

$\begin{array}{ll}\text { White-crowned sparrow } & \mathrm{Nu} \text { SpW } \\ \text { Pintail } & \mathrm{Nu} \text { Pnl } \\ \text { Green-winged teal } & \mathrm{Nu} \text { TeG } \\ \text { Canada goose } & \mathrm{Nu} \text { GpC } \\ \text { Red-backed sandpiper } & \mathrm{Nu} S Q\end{array}$

$d$ Irregular visitants : appear at irregular intervals, usually but not always in winter, New York State being outside their normal range

$\begin{array}{lll}\text { Evening grosbeak } & \mathrm{Nu} & \mathrm{GtE9} \\ \text { Cardinal } & \mathrm{Nu} & \mathrm{Cb} \\ \text { Sooty tern } & \mathrm{Nu} & \mathrm{TfS} \\ \text { Gull-billed tern } & \mathrm{Nu} & \mathrm{TfG}\end{array}$

3 Time of migration

January is the only month when there is no migration; spring migration usually begins in February and continues until June. 
The fall migration begins with the flocking of the swallows in July and continues until December.

$a$ Spring migration, February to June

(1) Earliest migrants-February 15th to March 10th

$\begin{array}{lll}\text { Prairie horned larks } & \mathrm{Nu} & \text { LdP9 } \\ \text { Robin } & \mathrm{Nu} & \mathrm{Ro6} \\ \text { Bluebird } & \mathrm{Nu} & \mathrm{Bm} 8 \\ \text { Redwings and grackles } & \mathrm{Nu} & \mathrm{Bl} 5 \\ \text { Canada goose } & \mathrm{Nu} & \mathrm{GpC} 8 \\ \text { Fox sparrow } & \mathrm{Nu} & \mathrm{SpG}\end{array}$

(2) Latest migrants, May 10th to June 10th

$\begin{array}{lll}\text { Olive-backed thrush } & \mathrm{Nu} & \mathrm{TiO} \\ \text { Short-billed marsh wren } & \mathrm{Nu} & \mathrm{WrS1} \\ \text { Wood pewee } & \mathrm{Nu} & \mathrm{Pi} 7 \\ \text { Semipalmated plover } & \mathrm{Nu} & \mathrm{PpS}\end{array}$

$b$ Fall migration

(1) Early flocking in July

Swallows on wires

$\mathrm{Nu}$ SuT8

(2) Early migrants in late July and early August
Least sandpiper
$\mathrm{Nu} \quad \mathrm{SL}$
Solitary sandpiper
$\mathrm{Nu} \quad \mathrm{SS}$

(3) Late migrants October and November

$\begin{array}{lll}\text { Phoebe } & \mathrm{Nu} & \mathrm{Pi} \\ \text { Mallard } & \mathrm{Nu} & \mathrm{Mc} 82\end{array}$

Photographed in March, but the dabbling ducks are among the last birds to leave in fall.

4 Method of migrating

a Regular-shaped flocks

Canada geese

$\mathrm{Nu} \quad \mathrm{GpC7}$

$b$ Irregular-shaped flocks

Black ducks

$\mathrm{Nu} \quad \mathrm{DuB} 8$

Sandpipers

$\mathrm{N} \iota$ SL8

5 Route of migration

Map of Trunk Lines of Migrating Birds. From The School Arts Magazine, February 1915

Nu ZM1 
Map Showing Spring and Fall Migration Routes of Golden Plover with Inset of Female Bird. Map after one in Bulletin 185, U. S. Department of Agriculture; bird, specimen in New York State Museum. (1919)

Nu ZM5

Map Showing Wide Migration Route: Distribution and Migration of the Redstart, with Inset of Male Bird. Map after one in Bulletin 185, U. S. Department of Agriculturn; bird, specimen in New York State Museum. (1919)

Map Showing Narrow Migration Route: Distribution and Migration of the Scarlet Tanager, with Inset of Male Bird. Map after one in Bulletin 185, U. S. Department of Agriculture; bird, specimen in New York State Museum. (1919)

Nu ZM6

$\mathrm{Nu} \quad \mathrm{ZM7}$

6 Distance of migration

$a$ Short. Birds retire to southern part of breeding range

Map Showing Winter and Summer Range of Robin, with Inset of Male Bird. Map after one in Bulletin 185, U. S. Department of Agriculture; bird, specimen in New York State Museum. (1919)

Map Showing Winter and Summer Range of Bluebird, with Inset of Male Bird. Map after one in Bulletin 185, U. S. Department of Agriculture; bird, specimen in New York State Museum. (1919)

$\mathrm{Nu} \quad$ ZM54

$\mathrm{Nu} \quad \mathrm{ZM} 2$

$b$ Medium. Winter home entirely south of breeding range, but no great distance

Distribution and migration of redstart $\quad$ Nu ZM6

\section{$c$ Long}

Map Showing Distribution and Migration of Bobolink, with Inset of Male Bird. Map after one in Bulletin 185, U. S. Department of Agriculture; bird, specimen in New York State Museum. (1919)

$\mathrm{Nu}$ ZM25

7 The sense of direction in birds as shown by their return to nesting site of previous year

Bald eagle

$\mathrm{Nu}$ EB

Nests of phoebe of two years side by side

Oriole building new nest near old one

$\mathrm{Nu}$ Pk32

$\mathrm{Nu} \mathrm{OrB3}$ 


\section{Economic Importance of Birds}

In the fields, gardens, orchards and woodlands there are innumerable insect pests all striving to gain the upperhand and threatening to consume everything green on the face of the earth. These insects are endowed with a great reproductive capacity and, were there no checks upon their increase, the world would soon be uninhabitable. Nature has designed the birds for this work. "Were it not for the birds," the chief of the United States Biological Survey has stated, "within a short time, not only would successful agriculture become impossible but the destruction of the greater part of the vegetation would follow."

\section{Insect pests and birds that destroy them}

The number of insects consumed each day by birds is enormous. One need only watch a pair of birds at their nest feeding their young to be amazed by the numbers which they consume. A pair of grosbeaks, for example, fed their young 376 times in one day; a pair of vireos that were watched, 450 times; a pair of chickadees 470 times and one wren, its mate having been killed, 1726 times in the 15 hours of daylight. The young birds are always hungry and the old birds keep up an almost constant supply of food. Again, in examining the stomachs of birds, the Biological Survey at Washington has uncovered some astonishing facts as to the number of insects eaten. In one cedar waxwing's stomach, for example, were found 100 cankerworms, in the stomach of a cuckoo were 350 caterpillars. A flicker had eaten 1000 chinch bugs. The following pictures show birds in the act of eating some of the worst pests that are known to agriculture. They are single concrete examples of what the birds are doing at all times.

Army worms, bobolink

White grubs, meadowlark

Apple Tree Tent-caterpillars: Egg Mass, Newly Hatched Larvae and First Tent. (1916)

Tent-caterpillars, yellow-billed cuckoo

Bark beetles, downy woodpecker

Work of Fruit Tree Bark Beetle on Apple and Plum Trees; Woodpeckers' Holes. Specimens, New York State Museum. (1918)

Cabbage worms, chipping sparrow
$\mathrm{Nu}$ Bo

$\mathrm{Nu}$ Mf1

$$
\begin{array}{ll}
\text { Nrr } & \text { Ta2 } \\
\text { Nu } & \text { CvY5 } \\
\text { Nu } & \text { WpD7 }
\end{array}
$$

Nru Ba9

$\mathrm{Nu} \quad \mathrm{SpC} 3$ 
Larvae of Cabbage Butterfly on Cabbage

Leaf. (1916)

Canker worms, mourning warbler

Cut worms, bluebird

All garden insects, wren

$\mathrm{Nrq} \quad \mathrm{C} 4$

$\mathrm{Nu}$ WN

$\mathrm{Nu} \quad \mathrm{Bm}$

$\mathrm{Nu} \quad \mathrm{WrH} 8$

2 Birds as destroyers of weed seeds

Some birds, like the mourning dove and goldfinch, feed upon weed seeds at all times of the year; others, like the majority of sparrows, feed upon insects during the summer and seeds during the rest of the year. Some of the greatest weed destroyers are winter residents with us and feed upon such weeds as project above the snow.

$\begin{array}{ll}\text { Prairie horned larks } & \mathrm{Nu} \text { LdP9 } \\ \text { Tree sparrow } & \mathrm{Nu} \text { SpT8 } \\ \text { Song sparrow and white-throat } & \mathrm{Nu} \text { SpR72 } \\ \text { Fox sparrows } & \mathrm{Nu} \text { SpG } \\ \text { Junco } & \mathrm{Nu} \text { JuS } \\ \text { Goldfinch } & \mathrm{Nu} \text { Go }\end{array}$

3 Birds as destroyers of rodents

Still more important are certain birds in the destruction of small rodents. A conservative estimate puts the possible offspring from one pair of meadow mice at 35 a year. At this rate it would take but five years to produce over three million mice from one pair. A single mouse can be quite destructive and when there are many the aggregate destruction often amounts to thousands of dollars. During the winter mice often work under the snow and girdle even rather large trees. Every hawk and owl requires the equivalent of three mice a day to live, or over a thousand a year.

$a$ General

Owl pellets

Nu Ow9

Owls have the habit of swallowing their prey whole, bones, fur and all and later ejecting from the mouth the indigestible parts in the form of pellets. By examining these pellets, one can determine what they have been feeding upon.

Nest of great horned owl

Food of great horned owl

$\mathrm{Nu}$ OwG3

$\mathrm{Nu}$ OwG9

$b$ Beneficial hawks

Red-tailed

$\mathrm{Nu}$ HR9

Sparrow hawk

$\mathrm{Nu}$ HT 


\section{$c$ Destructive hawks}

Three or four of the hawks feed largely upon birds or poultry and they are therefore more destructive than beneficial. They are the goshawk, the cooper, the sharp-shinned and the duck. The largest of the owls, the great horned, likewise sometimes takes poultry and is regarded as destructive. The rest of the hawks and owls occasionally take small birds or poultry, but they far more than make up for it in their destruction of small rodents.

Cooper hawk

$\mathrm{Nu} \quad \mathrm{HC} 4$

$d$ Peculiarities of shrikes

Northern shrike

$\mathrm{Nu} \quad \mathrm{SiN8}$

4 Birds as scavengers

The fourth way in which birds are of value to man is in cleaning up the lakes and harbors of waste and dead fish and in feeding upon dead animals that would otherwise pollute the air and contaminate our water supply. About lakes and harbors it is chiefly the gulls, and in the woods and fields the crows and the vultures that perform this important work.

Herring gulls
Herring gulls
Crows
Vulture
Vulture

$\begin{array}{ll}\mathrm{Nu} & \mathrm{GvH} 1 \\ \mathrm{Nu} & \mathrm{GvH8} \\ \mathrm{Nu} & \mathrm{Cu} 8 \\ \mathrm{Nu} & \mathrm{VuT} 4 \\ \mathrm{Nu} & \mathrm{VuT} 8\end{array}$

\section{Game birds}

The fifth way in which birds serve man is as game in supplying health-giving sport and food for the table. Certain birds like the water fowl, the grouse and the pheasants seemed designed by nature to serve as game. Their flesh is excellent, their reproductive capacity is large and their wits are keen. When given sufficient protection by the game laws and when these laws are respected, they ordinarily are able to maintain their numbers and in recent years have been increasing. Emphasis should be laid, however, upon the necessity for obeying the game laws, if the game birds of the country are not to be exterminated, and upon the value of real sportsmanship in hunting. A large number of hunters, when they take out their guns, seem to lose their ideals of manliness, honesty or even common decency and go through the country like hoodlums breaking down fences, 
destroying signs and shooting at everything that flies or runs. What is needed in the country are law-abiding, gentlemanly hunters who will respect the laws and guide their conduct in the field by the same principles that they respect in their homes, schools or places of business.

Baldpate
Coot
Mallards
Pintail
Pintail
Teal
Teal
Canvasback
Scaup ducks
Scaup ducks
Black ducks
Gallinule
Goose
Goose
Canada grouse
Ruffed grouse
Bobwhite
Hungarian partridge
Pheasant
Black-bellied plover
Sora
Virginia rail
Woodcock
Yellowlegs
Yellowlegs
Greater yellowlegs

$\begin{array}{ll}\mathrm{Nu} & \mathrm{Bc1} \\ \mathrm{Nu} & \mathrm{Cn} \\ \mathrm{Nu} & \mathrm{Mc} 82 \\ \mathrm{Nu} & \mathrm{Pn} \\ \mathrm{Nu} & \mathrm{Pn} 1 \\ \mathrm{Nu} & \mathrm{TeG} \\ \mathrm{Nu} & \mathrm{TeG} 1 \\ \mathrm{Nu} & \mathrm{Ca6} \\ \mathrm{Nu} & \mathrm{DuS7} \\ \mathrm{Nu} & \mathrm{DuS} 9 \\ \mathrm{Nu} & \mathrm{Ca} 92 \\ \mathrm{Nu} & \mathrm{GcF} 7 \\ \mathrm{Nu} & \mathrm{GpC} \\ \mathrm{Nu} & \mathrm{GpC} 9 \\ \mathrm{Nu} & \mathrm{GuC} \\ \mathrm{Nu} & \mathrm{GuR} 2 \\ \mathrm{Nu} & \mathrm{Bp} 4 \\ \mathrm{Nu} & \mathrm{PcH} \\ \mathrm{Nu} & \mathrm{PjR} \\ \mathrm{Nu} & \mathrm{PpB} \\ \mathrm{Nu} & \mathrm{So} \\ \mathrm{Nu} & \mathrm{RV} \\ \mathrm{Nu} & \mathrm{Wo} \\ \mathrm{Nu} & \mathrm{Yd} \\ \mathrm{Nu} & \mathrm{Yd} 8 \\ \mathrm{Nu} & \mathrm{YdG}\end{array}$

6 Some birds that are at times destructive

While the majority of birds are working for us at all times, there are a few in addition to the hawks and the owl mentioned that are at times quite destructive. The majority of these birds are very beneficial except for certain short periods of the year, and we should therefore be glad to put up with their depredations for the sake of having them at other times of the year.

\section{$a$ Fruit eaters}

All birds are fond of fruit and, when they can not find wild fruits, they make themselves annoying in the orchard and garden. Particularly is this true of some of our best birds like the robin, catbird, waxwing, thrushes etc. The harm thus done by these birds may be avoided by planting plenty of mulberries or 
wild fruits that mature at the same time as the cultivated ones to be protected.

Waxwing

$\mathrm{Nu}$ Wg5

$b$ Grain eaters-crows, grackles and red-winged blackbirds

In places near large marshes or where these birds congregate by the thousands, great destruction is wrought by them and one must needs be continually changing his scare crows and driving them away to protect his crops. Shooting the birds is of little avail as the number killed is at best but a very small fraction, while the noise of the gun is just as effective in frightening them away. During the summer months these birds feed upon insects, and they should therefore not be killed.

$\begin{array}{lll}\text { Grackle } & \mathrm{Nu} & \mathrm{GrB7} \\ \text { Red-winged blackbirds } & \mathrm{Nu} & \mathrm{B} 192\end{array}$

$c$ Destroyers of eggs and young of other birds

A third way in which some birds incur disfavor is in their depredations upon other small birds, stealing their eggs or eating the young. The crows, jays, grackles and red-headed woodpeckers are the worst culprits, but even the wrens like to break the eggs of other birds nesting near them. Most birds are able to defend their nests against their natural enemies, and it is usually the weaker individuals that are preyed upon. This is necessary to maintain the strength of the species so to have a few of these natural enemies is desirable.

Broken eggs of blackbird

$\mathrm{Nu} \quad \mathrm{B} 132$

\section{$d$ Usurpers}

The house sparrow stands in disfavor chiefly because the native birds can not compete with him and he is rapidly usurping the place of such birds as bluebirds, tree swallows, wrens and the hole-nesting species. Birds of this species travel in such large flocks and are ready to nest so long before the other birds arrive in the spring that the competition is quite unfair.

\section{Photography}

Four Pictures, Two of Meadowlark and Two of Cardinal, to Show the Differences between Genuine and Fake Bird Photography. (1919) 
No. 1 is doubtless a dead cardinal. Compare the eye with that of no. 2. Note how dull and expressionless it is. How do the crests differ? The entire pose or expression of no. 2 is animated, that of no. 1 is lifeless. In this entire collection of bird pictures there is not one of a live bird on such a perch as that of no. 1 . In photographing a bird the camera must almost always be set up in advance. Even if a bird would choose such a perch as this, one could not anticipate its doing so. The "nature faker" who made the photograph had two motives for putting a stuffed bird in this position, first, to. give an attractive setting; second, to cover the wires or other means of fastening the specimen to the perch.

Compare nos. 3 and 4. Note especially that in this case, where the faker did not conceal the support of the bird, the feet are almost entirely covered with earth. What other evidences can you observe that one bird was dead and the other alive? Honesty is the first requisite of one who would be a real student. One of the ends of learning is to detect untruth.

Doctor Allen photographing himself and a chickadee

$\mathrm{Nu} \quad \mathrm{Ci} 86$

Prairie horned lark sitting on camera with which she had just been photographed feeding her young

$\mathrm{Nu} \quad$ LdP8

Doctor Chapman photographing himself and an osprey

Chickadee nest shown by cutting out piece of tree trunk

Chickadee

Bluebird on electric perch

Umbrella Blind Set Up in Cat-tails; Two Young Red-winged Blackbirds on Perch before Opening for Camera. Ithaca. (1915) Allen

Trailer Blind of G. A. Bailey for Observing and Photographing Birds. (April 1917)

$\mathrm{Nu} \quad \mathrm{Os} 7$

$\mathrm{Nu} \mathrm{Ci3}$

$\mathrm{Nu} \quad \mathrm{Ci} 6$

$\mathrm{Nu} \quad \mathrm{Bm} 1$

$\mathrm{Nu} \quad \mathrm{ZP}$

$\mathrm{Nu} \quad \mathrm{ZP} 1$

This trailer $\mathrm{Mr}$ Bailey attaches to a Ford car. It is large enough to live in comfortably. Note openings for outlooks and cameras. 



